\title{
4.13 Composition of the Oceanic Crust
}

WM White, Cornell University, Ithaca, NY, USA

EM Klein, Duke University, Durham, NC, USA

(c) 2014 Elsevier Ltd. All rights reserved.

\begin{tabular}{lll}
\hline 4.13.1 & Introduction & 457 \\
4.13.2 & Architecture of the Oceanic Crust & 458 \\
4.13 .2 .1 & Vertical Structure & 458 \\
4.13 .2 .2 & Ridge Segmentation & 459 \\
4.13 .2 .3 & Morphology, Structure, and Spreading Rate & 459 \\
4.13 .2 .4 & Magmatic Processes and Magma Chambers & 460 \\
$\mathbf{4 . 1 3 . 3}$ & Creation of Oceanic Crust at Mid-Ocean Ridges & 462 \\
4.13 .3 .1 & Mantle Flow and Melting & 462 \\
4.13 .3 .2 & Melt Extraction and Flow & 464 \\
4.13 .3 .3 & Crystallization & 464 \\
$\mathbf{4 . 1 3 . 4}$ & The Composition of MoRB & 466 \\
4.13 .4 .1 & The Average Composition of MORB & 466 \\
4.13 .4 .1 .1 & Major elements & 466 \\
4.13 .4 .1 .2 & Trace elements & 466 \\
4.13 .4 .1 .3 & Isotope ratios & 472 \\
4.13 .4 .2 & Regional Variations in MORB Composition & 476 \\
4.13 .4 .2 .1 & Regional isotopic variations & 476 \\
4.13 .4 .2 .2 & Regional major element variations & 480 \\
4.13 .4 .3 & Estimating the Bulk Composition of the Oceanic Crust & 484 \\
4.13 .4 .4 & The Composition of Back-Arc Basin Crust & 486 \\
4.13.5 & Future Directions & 490 \\
Acknowledgments & & 492 \\
References & & 492 \\
\hline
\end{tabular}

\subsubsection{Introduction}

When Harry Hess first proposed the theory of seafloor spreading, he imagined that mantle peridotite upwelling at midocean ridges reacted with water to form a serpentinite oceanic crust (Hess, 1962). The seafloor spreading concept proved correct, but his original hypothesis missed one important point: mantle upwelling beneath mid-ocean ridges undergoes decompression melting, and these melts rise buoyantly to the surface to form a basaltic, rather than serpentinitic, oceanic crust. Approximately $60 \%$ of the Earth's surface consists of oceanic crust (Cogley, 1984), and most of it has formed in this way at divergent plate boundaries called mid-ocean ridges or spreading centers (Figure 1). The global rate of ocean crust production is $3.4 \mathrm{~km}^{2}$ year ${ }^{-1}$; how this may have varied in the past is a matter of debate (e.g., Müller et al., 2008; Rowley, 2002, 2008). Additionally, oceanic crust can be created, or at least substantially thickened, when mantle plumes generate melt that erupts through the oceanic lithosphere, creating oceanic islands or oceanic plateaus. Oceanic islands and plateaus are reviewed elsewhere in this treatise (see Chapters 3.3 and 4.18 , respectively) and neither will be discussed here. Once created, the oceanic crust is transported off-axis to each side of the spreading center, accumulating sediment (see Chapter 4.17) and becoming progressively altered (see Chapter 4.16) as it ages. It is ultimately consumed at subduction zones and returned in a modified form to the mantle (see Chapters 4.19, 4.20, and
4.21). Thus, in contrast to continental crust, oceanic crust is ephemeral: its mean age is about $60 \mathrm{Ma}$ (Cogné et al., 2006) and it is nowhere older than about $167 \mathrm{Ma}$ (Koppers et al., 2003), except in the Eastern Mediterranean where in situ crust as old as 270 Ma may be preserved (Müller et al., 2008).

The oceanic crust plays a key role in the on-going processes that modify the compositions of major Earth reservoirs. As the product of mantle melting, the generation of new oceanic crust continuously changes the composition of the upper mantle from which it forms. This has a profound effect on the mantle, because, if the present rates of ocean crust production are typical of those in the past, a considerable fraction of the mantle has melted to produce the oceanic crust. The ocean crust is also a primary interface of exchange between fluids of the Earth's surface and the solid Earth below. Hydrothermal circulation of seawater through the ocean crust, for example, is a major factor controlling the chemistry of seawater (e.g., see Chapters 8.7 and 4.16). Subduction and consequent dehydration, and in some instances melting of fresh to variable altered oceanic crust, is believed to initiate island-arc volcanism, and the particular composition of the subducting crust affects the compositions of the island-arc magmas (e.g., see Chapters $4.17,4.19,4.20$, and 4.21). The deep subduction of altered oceanic crust is also the primary means of recycling material from the surface back to the mantle, where, convectively mixed with ambient mantle, it may form both the source of some hot spots and dispersed chemical heterogeneities 


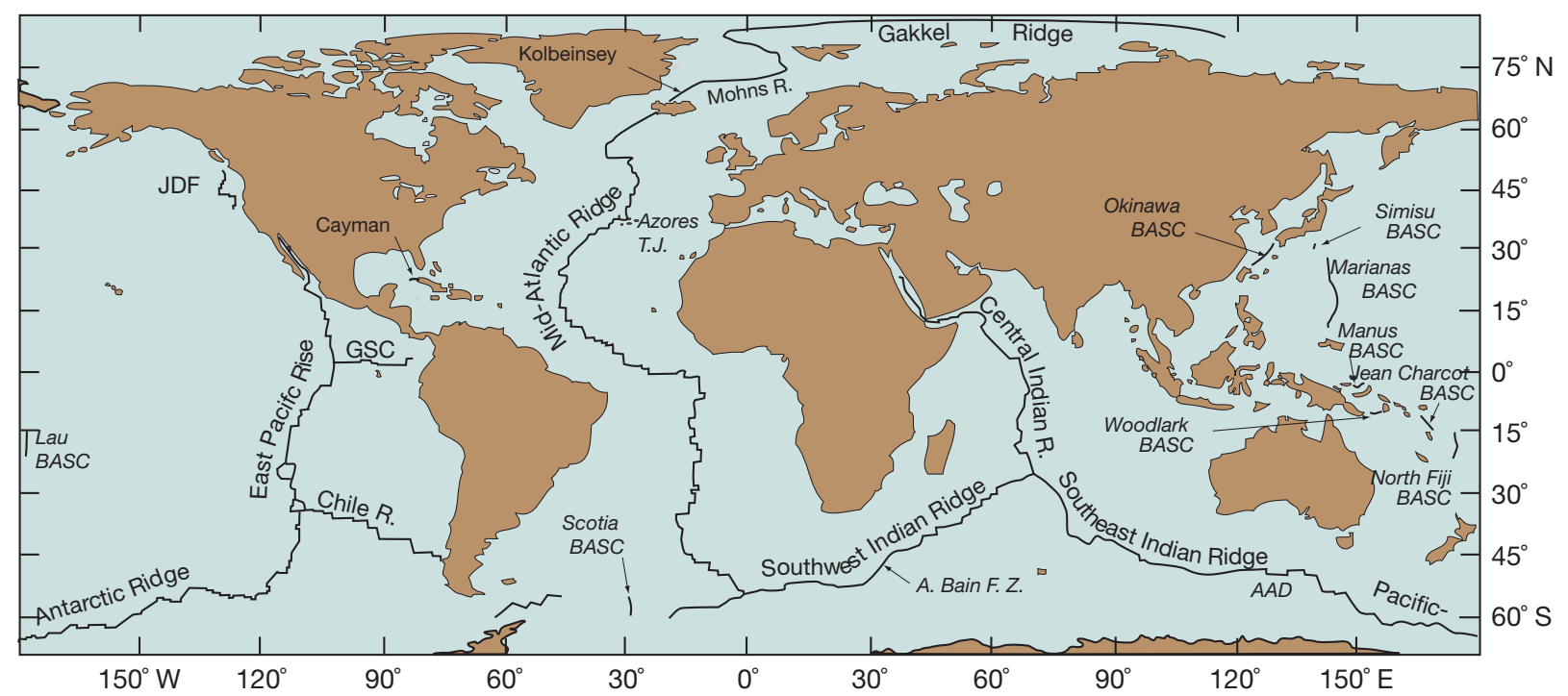

Figure 1 Map of the global mid-ocean ridge system. Names of back-arc basin spreading centers (BASC) are shown in italics. Locations of the Azores triple junction (Azores T. J.), the Andrew Bain Fracture Zone (A. Bain F. Z.), Juan de Fuca Ridge (JDF), Galapagos Spreading Center (GSC), and the Australian-Antarctic discordance (AAD) are also shown.

(Hofmann and White, 1982; see also Chapter 3.3). Changes in the rates of seafloor spreading, and consequently the age and elevation of oceanic crust, have been a major cause of eustatic sea-level change over the past $180 \mathrm{Ma}$ (Cogné et al., 2006). Thus, an understanding of the processes and rates of formation of the oceanic crust is central to our elucidation of fundamental and diverse geologic processes.

This chapter reviews the architecture of the oceanic crust, the geochemical processes by which it is created, as well as its major element, trace element, and isotopic composition. The principal focus is on the more readily sampled volcanic upper oceanic crust; the gabbroic lower crust is reviewed by Coogan (see Chapter 4.14). The oceanic crust begins to react with seawater as soon as it is created and these processes eventually result in significant modification of its composition. This hydrothermal alteration is reviewed by Staudigel (see Chapter 4.16); consequently, this chapter focuses exclusively on the pristine magmatic composition of oceanic crust. Finally, oceanic crust acquires a veneer of sediment, the nature and composition of which is reviewed by Plank (see Chapter 4.17). More detailed perspectives on these and related topics such as melting and melt percolation models (see Chapter 4.15), mantle heterogeneity (see Chapter 3.3), and subduction zone processes (see Chapters 4.19, 4.20, and 4.21 ) are presented elsewhere in these volumes.

\subsubsection{Architecture of the Oceanic Crust}

\subsubsection{Vertical Structure}

The structure of igneous oceanic crust (Figure 2) has been deduced from seismic studies, drilling of the ocean crust, exposures of the deeper crust at fracture zones and rare tectonic windows, and studies of portions of the oceanic crust that have been obducted onto land (ophiolites). The uppermost layer consists of basaltic lava flows. In ODP Hole 504B, this extrusive layer is $780 \mathrm{~m}$ thick (Alt et al., 1993); in ODP Hole 1256D, it is $881 \mathrm{~m}$ thick (Umino et al., 2008). It averages $800 \mathrm{~m}$ thick in the Hess Deep (Karson et al., 2002). A 20-60-m-thick transition zone typically separates the eruptive layer from the underlying sheeted dike complex, which forms as magma freezes in dikes, typically $0.5-2 \mathrm{~m}$ wide, that feed the eruptions that form the overlying extrusive layer. The sheeted dike complex is $350 \mathrm{~m}$ thick in Hole 1256D and $1060 \mathrm{~m}$ thick in Hole 1256D (Alt et al., 1993; Umino et al., 2008, respectively). In the Hess Deep, near the East Pacific Rise (EPR), the sheeted dike complex varies in thickness from 300 to $1200 \mathrm{~m}$ (Karson, 2002). Seismic reflection and refraction studies are also used to estimate the thicknesses of lava and dike units (e.g., Harding et al., 1989; Toomey et al., 1990; Vera et al., 1990). Together, the lavas and dikes are believed to constitute seismic layer 2 (layer 1 is the sediments), which is subdivided into layer $2 \mathrm{~A}$, thought to correspond to the lavas, and layer $2 \mathrm{~B}$, thought to correspond to the dikes. On the flanks of the ocean ridge, the average thickness of the layer 2A ranges from $\sim 350$ to $650 \mathrm{~m}$, which is somewhat smaller than estimates based on drill cores or observations at tectonic windows (see review by Carbotte and Scheirer, 2004). Recent studies suggest, however, that the seismically identified base of layer 2A may represent an alteration boundary rather than the base of the extrusive layer (e.g., Christeson et al., 2007). The combined thickness of layers $2 \mathrm{~A}$ and $2 \mathrm{~B}$ (the upper crust) appears to vary with spreading rate, ranging from $\sim 1$ to $1.5 \mathrm{~km}$ at fast-spreading ridges, and 2 to $3 \mathrm{~km}$ at intermediate- to slow-spreading ridges (Carbotte and Scheirer, 2004). Layer 2 is underlain by seismic layer 3, consisting of intrusive gabbroic rocks of diverse textures and lithologies, as reviewed by Coogan (see Chapter 4.14). The total thickness of oceanic crust averages about $6.5 \mathrm{~km}$, meaning that the gabbroic layer is typically $3.5-5.5 \mathrm{~km}$ thick and constitutes the bulk of the oceanic crust. It is important to emphasize that these are average ocean crust characteristics. The thickness of the crust, and of individual units, can vary locally where melting is either enhanced (e.g., the Co-Axial segment of the Juan 


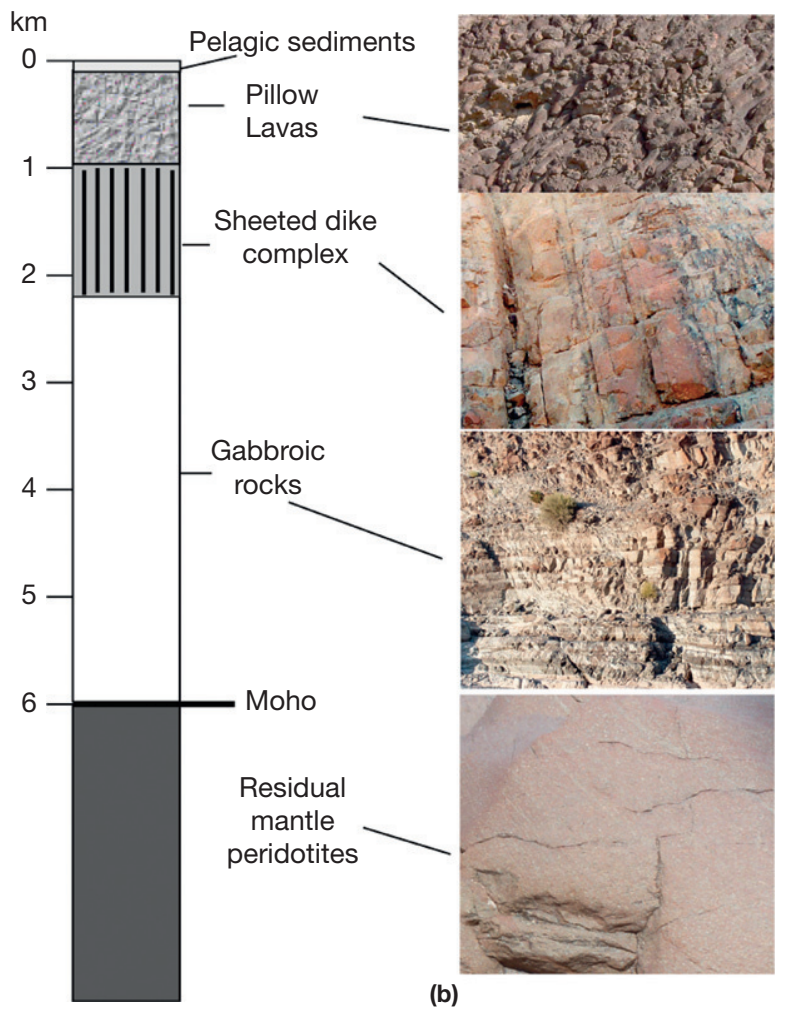

(a)

Figure 2 (a) Generalized internal structure and interpretation of the oceanic crust derived from studies of ophiolite complexes and interpretations of marine seismic and geologic data; (b) Outcrop photographs from the Semail ophiolite, Oman. Photo credits: pillow lavas, L. M. Cathles; others, C. Andronicos. After Karson JA (2002) Geologic structure of the uppermost oceanic crust created at fast- to intermediate-rate spreading centers. Annual Reviews of Earth and Planetary Sciences 30: 347-384.

de Fuca Ridge; Carbotte et al., 2008) or reduced (e.g., the ultraslow-spreading Gakkel Ridge; Jokat et al., 2003), as well as due to variations in mantle temperature, as discussed below.

\subsubsection{Ridge Segmentation}

The approximately 65000-km-long global ocean ridge system is divided into segments of varying scales. At the largest scale, long segments of ridge, typically hundreds to thousands of kilometers in length, are named for geographical (e.g., the EPR), historical (e.g., the Gakkel Ridge for a polar explorer), or other reasons. At smaller scales, a hierarchy of transform and nontransform offsets tectonically segment mid-ocean ridges (Macdonald et al., 1988, 1991). First-order segments are of the order of $300-500 \mathrm{~km}$ in length and are bounded by major transform faults that offset the ridge by up to hundreds of kilometers and commonly persist for tens of millions of years or more. Second-order discontinuities are shorter lived, persisting for 1-2 million years. On fast-spreading ridges, second-order segments, which are typically $50-300 \mathrm{~km}$ in length, are bounded by large overlapping spreading centers that offset the ridge by $\sim 5-10 \mathrm{~km}$. On slow-spreading ridges, second-order segments are commonly less than $100 \mathrm{~km}$ in length and are bounded by oblique shear zones that offset the ridge 15-30 km (Macdonald et al., 1988, 1991; Sempere et al., 1993). Third-order segments, which are typically $10-50 \mathrm{~km}$ in length, are bounded by smaller, short-lived, overlapping spreading centers on fast-spreading ridges, with typical offsets of $0.5-2 \mathrm{~km}$, and by steps in the rift valley walls or gaps in chains of volcanoes on slow-spreading ridges. Fourth-order segments are typically $10 \mathrm{~km}$ in length, with even shorter lived offsets consisting of small bends or other 'deviations from axial linearity' (devals; Langmuir et al., 1986) on fast-spreading ridges and manifest as small depth anomalies or gaps in volcanic chains on slow-spreading ridges.

In some areas, there is clear evidence of a correspondence between these hierarchical scales of tectonic segmentation and magmatic segmentation in the form of changes in magma composition across segment boundaries (e.g., Langmuir et al., 1986; Perfit et al., 1994; Sims et al., 2002; Smith et al., 2001). In an examination of lavas erupted along the southern EPR, for example, Sinton et al. (1991) showed that isotopically coherent domains (primary magmatic segments) several hundred kilometers in length are bounded by large-offset overlapping spreading centers. Nested within these primary magmatic segments are numerous secondary magmatic segments that share a common parental magma composition, and are bounded by smaller offset overlapping spreading centers. Detailed study of variations in lava composition along the northern and southern EPR found that third-order segment boundaries often correspond with changes in the extent of crystallization, as well as variations in the underlying magma lens, and thus may represent a fundamental aspect of volcanic segmentation (e.g., Smith et al., 2001; White et al., 2002). About $30 \%$ of fourth-order segment boundaries coincide with changes in magma composition (Grevemeyer et al., 2002; Langmuir et al., 1986; Sinton et al., 1991), and likely represent individual diking or eruption events (e.g., Haymon et al., 1991; White et al., 2002). It should be noted, however, that even along fast-spreading ridges, where the higher order tectonic features are most easily identified, not all large-offset transforms correspond to changes in isotopic or source composition (e.g., the Clipperton transform), and there may be variations in composition that grade continuously across several hundred kilometers of ridge, irrespective of the presence of overlapping spreading centers or devals (e.g., $12-14^{\circ} \mathrm{N}$ EPR; Castillo et al., 2000).

\subsubsection{Morphology, Structure, and Spreading Rate}

The morphology and structure of mid-ocean ridges varies with spreading rate (see reviews by Carbotte and Scheirer, 2004; Macdonald, 2001; Perfit and Chadwick, 1998). Slow-spreading ridges, those with full spreading rates less than $4 \mathrm{~cm}_{\text {year }}{ }^{-1}$ such as the Mid-Atlantic Ridge (MAR), are characterized by fault-dominated topography. The plate boundary is marked by a prominent fault-bounded graben, or axial valley, that is typically $5-20 \mathrm{~km}$ wide and $1 \mathrm{~km}$ or more deep. Within the axial valley, mounds of pillow lava and accumulations of pillow hummocks form axial volcanic ridges. Available data suggest that individual eruptions on slow-spreading ridges are generally larger but more infrequent than at faster spreading ridges (Perfit and Chadwick, 1998). 
Fast-spreading ridges, with full spreading rates in excess of $8 \mathrm{~cm}$ year $^{-1}$, such as the EPR, have smoother topography and generally lack a prominent axial valley. Instead, there is typically a comparatively narrow axial summit trough or graben. Fornari et al. (1998) recognized two summit types: narrow axial troughs, $\lesssim 200 \mathrm{~m}$ wide and $\lesssim 15 \mathrm{~m}$ deep, formed by collapse of lava flow surfaces over eruptive fissures or conduits and larger (300-2000 m wide and 30-100 m deep), faultbounded axial summit graben of primarily tectonic origin. At fast-spreading ridges, the neovolcanic zone is commonly restricted to a kilometer-wide zone centered on the summit, although both off-axis eruptions and flows extending far offaxis do occur. Lavas are more often lobate, or form sheet flows, and have other features, such as large collapse pits, that suggest high lava volumes and high effusion rates, although pillow morphologies also occur, particularly near ridge offsets where effusion rates may be lower (White et al., 2009).

Intermediate-spreading ridges, with spreading rates between 4 and $8 \mathrm{~cm}_{\text {year }}{ }^{-1}$, have morphologies that vary between those typical of fast- and slow-spreading ones. Indeed, the intermediate-spreading Juan de Fuca Ridge has segments exhibiting the full range of morphologies (Carbotte et al., 2006; Stakes et al., 2006).

Ultraslow-spreading ridges, those with full spreading rates less than about $15 \mathrm{~mm}$ year $^{-1}$, such as the Gakkel Ridge in the Arctic and portions of the Southwest Indian Ridge (SWIR; DeMets et al., 2010), display some affinities with slow-spreading ridges but also include characteristics that are unique to the ultraslow-spreading environment. At the slowest spreading ocean ridge, the Gakkel Ridge, spreading rate decreases from $\sim 1.4 \mathrm{~cm}_{\text {year }}{ }^{-1}$ full rate in the west to $\sim 0.6 \mathrm{~cm}_{\text {year }}{ }^{-1}$ in the east, progressing through distinct tectonomagmatic domains (Jokat et al., 2003). The western volcanic zone is reminiscent of slow-spreading ridges and consists of 15-50-km-long volcanic ridges that rise from a deep and wide axial valley bounded by high-angle normal faults. Short segments containing small volcanic cones separate the volcanic ridges. Samples recovered were almost entirely fresh glassy pillow basalts. The transition into the central zone is marked by a small offset and abrupt deepening of the axial valley. The central zone, also called the sparsely magmatic zone, is characterized by a paucity of constructive magmatic features. Dredge recoveries in much of the central zone consist predominantly of peridotite and serpentinite, with rare older basalt and dolerite (Michael et al., 2003), suggesting intermittent magmatism (interestingly, amagmatic or sparsely magmatic ocean ridge segments such as this correspond best to Hess's original vision of seafloor spreading). The eastern volcanic zone consists of widely spaced volcanic edifices within the axial valley. Dredge recoveries in the eastern zone were dominated by basalt, with some peridotites and altered diabases also recovered.

The variations in spreading center morphology described above reflect the interplay between tectonic stretching of the lithosphere and its thermal state (Phipps Morgan and Chen, 1993). The thermal state, in turn, reflects the balance between magmatic and hydrothermal heat fluxes. When the magma flux is high, as it is along fast-spreading ridges, the axial lithosphere is weak, and ductile flow dominates over brittle deformation. When the magma flux is lower, as it generally is along slowspreading ridges, the lithosphere deforms more brittlely, resulting in rough topography and large axial grabens. The important role of the magmatic heat flux in governing axial morphology is demonstrated by the observation that magmatically robust segments of the slow- and intermediate-spreading ridges, such as segments of the Juan de Fuca and Reykjanes ridges, have morphologies more similar to those of fast-spreading ridges.

A relatively recent finding in the study of ocean ridge morphology is the prevalence of deformation processes at slowspreading rates that expose lower oceanic crust and mantle. While large-offset, low-angle extensional faults have long been suspected of exhuming gabbros and mantle peridotites at slow and ultraslow ocean ridges (e.g., Dick et al., 1981), only in the last decade or so have these features become a focus of attention. Investigation shows that extension can become localized along 'detachment faults' for several million years and expose large areas (hundreds of square kilometers) of lower crustal gabbros and mantle peridotites on the seafloor, creating smoothly corrugated topographic highs known as 'megamullions' or 'oceanic core complexes' (e.g., Blackman et al., 1998; MacLeod et al., 2009; Smith et al., 2006). In these areas, spreading becomes asymmetric. Oceanic core complexes now appear to be common along slow- and ultraslow-spreading ridges such as the MAR and SWIR. Indeed, Escartin et al. (2008) suggested that detachment faulting and oceanic core complexes occur along almost half the MAR between $12^{\circ} 30^{\prime} \mathrm{N}$ and $35^{\circ} \mathrm{N}$.

It appears that detachment faulting and megamullion formation can occur when magma accretion drops below 50\% of total extension (Tucholke et al., 2008). Detachment faults initiate at the surface as high-angle $\left(\sim 65^{\circ}\right)$ normal faults similar to those bounding the axial valley of normal ridge segments and rapidly flatten to dips of $\sim 30^{\circ}$. Strain localization results from seawater penetration and talc formation along the fault zones. It was initially thought that core complexes were amagmatic; it is now recognized that magmatism, and volcanism, may persist during core complex development. In that case, magma is generally emplaced into the footwall of the detachment fault, explaining the frequent presence of gabbro bodies at these core complexes (Dick et al., 2008; MacLeod et al., 2009).

\subsubsection{Magmatic Processes and Magma Chambers}

Over the past several decades, our understanding of the processes by which oceanic crust is created has advanced substantially, although it remains imperfect. Seismic reflection studies have revealed the existence of axial magma chambers (AMCs) beneath intermediate-spreading (4-6 $\mathrm{cm} \mathrm{year}^{-1}$ ) to fast-spreading $\left(>6 \mathrm{~cm} \mathrm{year}^{-1}\right)$ ridges, such as the Juan de Fuca Ridge and EPR (e.g., Detrick et al., 1987; Van Ark et al., 2007). These magma chambers can extend for tens of kilometers along the axis and appear to be steady-state features. The top of the AMC is typically at a depth of about $2 \mathrm{~km}$ (e.g., Detrick et al., 1987; Sinton and Detrick, 1992), although it can be as shallow as $0.76 \mathrm{~km}$ and as deep as $4.5 \mathrm{~km}$ (Van Ark et al., 2007). The AMC is typically only $0.5-1.5 \mathrm{~km}$ wide, but it can be as narrow as $0.25 \mathrm{~km}$ and as wide as $4 \mathrm{~km}$. Seismic refraction and tomographic studies suggest that the zone of melt is quite thin, only 50-100 m (e.g., Kent et al., 1990; Toomey et al., 1990). This overlies a deeper and wider $(>8 \mathrm{~km})$ mush zone (melt plus crystals) and partially solid transition zone 
that extends to the base of the crust. Based on measurements of seafloor deformation under ocean gravity waves in the $9^{\circ} \mathrm{N}$ region, Crawford and Webb (2002) concluded that the lower crustal melt zone contained $2.5-17 \%$ melt that was well connected in tubes or films. This implies that there is as much, and probably much more, melt in the deep crust as in the AMC above it. Crawford and Webb (2002) found that this lower crustal melt zone was generally less than $8 \mathrm{~km}$ wide, but widened approaching the overlapping spreading center at $9^{\circ} 03^{\prime} \mathrm{N}$. They also found a separate melt body near the bottom of the lower crust at $9^{\circ} 48^{\prime} \mathrm{N}$ beginning about $10-14 \mathrm{~km}$ east of the rise axis and extending at least $14 \mathrm{~km}$ off axis.

Melt from the mantle is focused toward the ridge (e.g., Phipps Morgan, 1987; Spiegelman and McKenzie, 1987) and replenishes both the mush zone and the melt lens where cooling and crystallization take place, forming the gabbroic layer. Periodically, extensional forces associated with seafloor spreading create a pathway for dike injection above the melt lens. Repeated dike injection forms the sheeted dike complex. If the dike pierces the surface, magma erupts on the ocean floor as lava, forming the eruptive layer. Below the crust lie mantle rocks that are the residues of a previous melting event that provided the melt that formed the ocean crust above, but may also locally include melt-rock reaction products, intrusive bodies, and cumulate ultramafic rocks (Dick et al., 1984, 2008; Johnson and Dick, 1992; Karson, 1998; Kelemen et al., 1997; Michael and Bonatti, 1985).

Steady-state magma chambers appear to be much rarer on slow-spreading ridges, as only a couple of examples have been found, thus far (e.g., Singh et al., 2006), although this may partly reflect the difficulty of identifying them in rough seafloor terrain. Based on present evidence, magma chambers on slow-spreading ridges appear to be ephemeral rather than permanent.

Perhaps remarkably, there appears to be no dependence of crustal thickness on spreading rate, down to spreading rates of $2 \mathrm{~cm}$ year $^{-1}$ (Figure 3). This suggests that the crustal creation process is substantially similar on both slow- and fast-spreading ridges. Differences in spreading rate, however, do result in differences in the thermal regime, which affect magmatic evolution within the crust, and these are discussed in greater detail in a subsequent section. Figure 3 also shows that, below about $2 \mathrm{~cm}$ year $^{-1}$, the crustal thickness decreases rapidly with decreasing spreading rate. Thus, crustal creation at ultraslowspreading ridges, such as the Gakkel Ridge, may differ in significant ways from that at faster spreading ridges. Dick et al. (2003) have argued that the near constancy of crustal thickness with spreading rate implies that mantle flow beneath spreading centers must have a buoyant component, at least beneath volcanically robust segments of ultraslow-spreading ridges, rather than being merely passive.

Volcanic eruptions on mid-ocean ridges have yet to be visually observed, with the exception of the portion of the ridge dominated by the Iceland hotspot. However, several eruptions have been detected seismically, and evidence of very recent eruptions has been serendipitously discovered at a number of sites. Recently, a 2005-2006 series of eruptions at $9^{\circ} 50^{\prime} \mathrm{N}$ on the EPR was recorded by ocean-bottom seismometers, several of which were enveloped in lava (Goss et al., 2010; Soule et al., 2007; Tolstoy et al., 2006). The eruption occurred in essentially the same area of the ridge where, in 1991, the immediate aftereffects were observed of a similar, but smaller eruption (Haymon et al., 1993). Geologic mapping, ${ }^{210} \mathrm{~Pb} /{ }^{226} \mathrm{Ra}$ dating (see Chapter 4.5 ), and paleomagnetic intensity dating suggest that several eruptions have occurred in the past 100 years in the superfast-spreading region near $17^{\circ} 30^{\prime} \mathrm{S}$ on the EPR (Bergmanis et al., 2007). Numerous eruptions have been detected seismically along spreading centers in the northeast Pacific (Dziak et al., 2007). At least three diking and eruption events occurred on the CoAxial Segment between 1981 and 1993, with the 1993 event being detected seismically (Embley et al., 2000). A 1986 eruption on the Cleft Segment of the Juan de Fuca Ridge produced a hydrothermal burst or 'megaplume' and new sheet flows (Embley et al., 1991) and

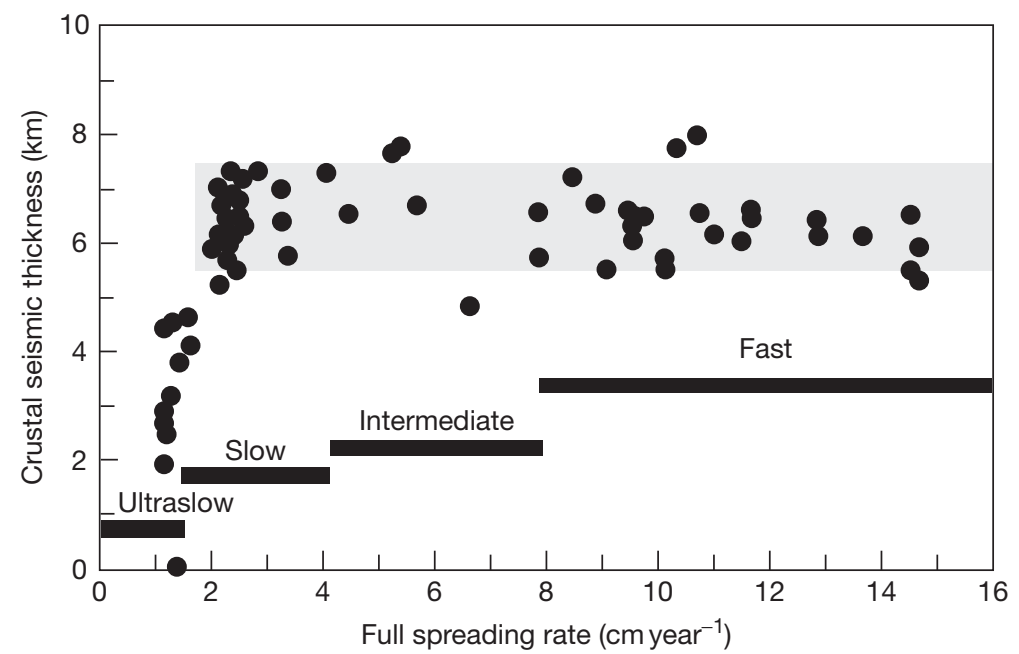

Figure 3 Crustal seismic thickness as a function of full spreading rate for ridge segments not influenced by hotspots. Crustal thickness appears to be independent of spreading rate above $2 \mathrm{~cm}_{\text {year }}{ }^{-1}$. Modified from White RS, Minshull TA, Bickle MJ, and Robinson CJ (2001) Melt generation at very slow-spreading oceanic ridges: Constraints from geochemical and geophysical data. Journal of Petrology 42: 1171-1196; Dick HJB, Lin J, and Schouten H (2003) An ultraslow-spreading class of ocean ridge. Nature 426: 405-412. 
pillow mounds (Embley and Chadwick, 1994), as did a 1996 eruption on the Gorda Ridge (Fox and Dziak, 1998). A 1998 eruption of Axial Seamount was monitored by in situ seafloor instruments, one of which was overrun and entrapped by the lava flow (Fox et al., 2001; Sohn et al., 2004). The Rose Garden hydrothermal system on the Galapagos Spreading Center (GSC), which was one of the initial hydrothermal vent communities discovered in 1979, was found to be buried by lava flows when revisited in 2002 (Shank et al., 2003). These observations are consistent with the eruption recurrence interval of a decade to a century or so for intermediate- to fast-spreading ridges estimated by Perfit and Chadwick (1998). Even on the ultraslow-spreading eastern Gakkel Ridge, side-scan sonar revealed very young lava flows where a seismic swarm had occurred in 1999 (Edwards et al., 2001; Sohn et al., 2008; Tolstoy et al., 2001).

\subsubsection{Creation of Oceanic Crust at Mid-Ocean Ridges}

\subsubsection{Mantle Flow and Melting}

In the simple passive model for mantle melting illustrated in Figure 4, viscous drag associated with seafloor spreading draws the mantle up from depth (e.g., Lachenbruch, 1976; McKenzie and Bickle, 1988; Oxburgh, 1965, 1980; Plank and Langmuir, 1992). Below the solidus, the mantle will rise adiabatically (isentropically) along a $T-P$ path given by $(\partial T / \partial P)_{S}=T \alpha V / C_{P}$, where $T$ is temperature, $\alpha$ is the coefficient of thermal expansion, $V$ is molar volume, and $C_{P}$ is heat capacity (Figure 4 ). This slope (which is curved because it depends on $T$ ) will be steeper than the slope of the solidus, which is given by the Clapeyron expression, $(\mathrm{d} T / \mathrm{d} P)=\Delta V_{\mathrm{m}} / \Delta S_{\mathrm{m}}$, where $\Delta V_{\mathrm{m}}$ and $\Delta S_{\mathrm{m}}$ are the volume and entropy change of melting, respectively. Consequently, provided the mantle is initially hot enough, it will eventually intersect the solidus and melting will begin. If the mantle is lithologically heterogeneous (e.g., eclogite veins embedded in a peridotite matrix), different lithologies may begin to melt at different depths, complicating the theromodynamics somewhat (e.g., Phipps Morgan, 2001). Once melting begins, the rising mantle will follow a shallower $T-P$ path because energy is being consumed by melting. Continued corner flow causes the mantle to rise further, melting more as it ascends; thus, the amount of melting that a parcel of mantle will experience is governed by the difference in pressure between the depth of intersection of the solidus $\left(P_{0}\right)$ and the depth at which it turns the corner and no longer decompresses $\left(P_{\mathrm{f}}\right.$, depth of final melting). Seismic studies suggest that beneath the EPR $P_{0}$ occurs (i.e., significant melting begins) at a depth of about $70-100 \mathrm{~km}$, although traces of melt may be present as deep as $150 \mathrm{~km}$ (Forsyth and the MELTS Seismic Team, 1998; Gu et al., 2005; Yang et al., 2007).

An important aspect of this and related models is that midocean ridge basalts (MORB) are not generated at a unique depth of melting or by a unique percentage of melting. Rather, they are mixtures of melts generated over a range of pressures and over a range of melting percentage, particularly in a lithologically heterogeneous mantle. A relatively large volume of the mantle contributes small-degree melts created at depth (Figure 5). A much smaller volume of mantle contributes large-degree melt fractions, and only a quite small volume of mantle rises all the

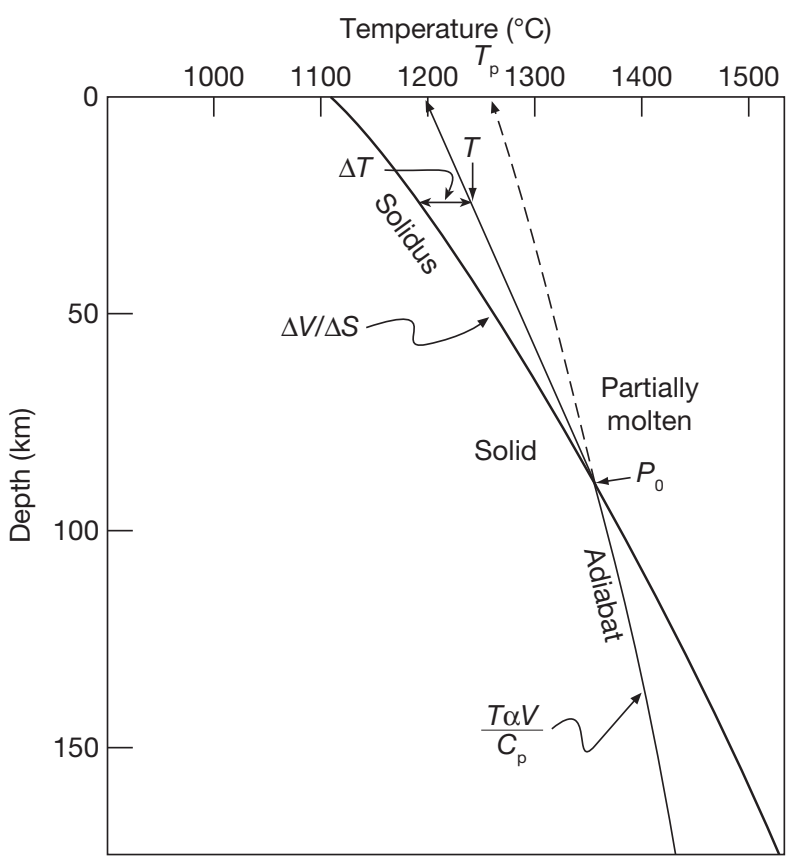

Figure 4 Thermodynamics of mantle upwelling and melting beneath a mid-ocean ridge. $P_{0}$ is the pressure at which melting begins, and $\Delta T$ is the excess temperature of the mantle relative to the solidus. Solid line shows the actual temperature path, and dashed line shows the temperature path if melting does not occur. $T_{\mathrm{p}}$ is the mantle potential temperature, that is, the temperature of mantle rock brought to the surface without melting; $T$ is the actual temperature. The extent of melting will depend on $\Delta T$, the difference between the solidus and actual temperatures. See text for further explanation.

way to the base of the crust directly beneath the spreading center and melts to the maximum extent. It is only this most highly melt-depleted peridotite that is likely to be exposed in fracture zones, oceanic core complexes, and ophiolites.

One can nevertheless define a mean pressure $(\bar{P})$ and mean extent of melting $(\bar{F})$, simply by integrating these parameters over the melting volume (Plank and Langmuir, 1992). In the simplest example, where the melting volume is an equilateral triangle, mantle upwelling velocity is constant across the base of the region, melting is a linear function of height above the base of the triangle, and all melt is focused to the ridge axis with equal efficiency, the mean extent of melting will be onethird the maximum and the mean pressure of melting will be the pressure one-third of the way up the melting region. However, incompatible elements, which are defined here as those elements strongly concentrated in a melt phase in equilibrium with a solid $(D<0.01)$, will be derived disproportionately from the regions undergoing only a small extent of melting, such that, for these elements, the effective mean extent of melting will be one-half the maximum extent of melting (Plank and Langmuir, 1992). In the model illustrated in Figures 4 and 5, there is an implicit relationship between the mean depth of melting $\bar{P}$, the depth of the initial intersection of the solidus $P_{0}$, the total height of the melting column, and the mean and maximum extent of melting. Hotter mantle will intersect the solidus at greater depth and higher pressure, resulting in a longer melting column and a larger mean and 
(a)

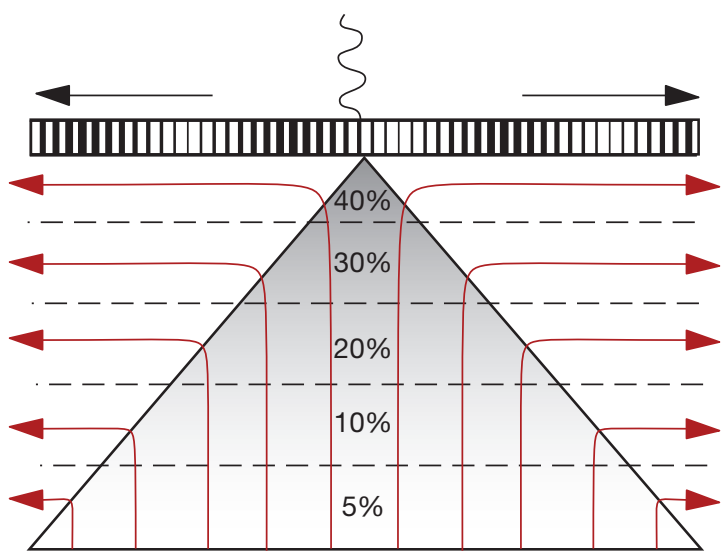

(b)

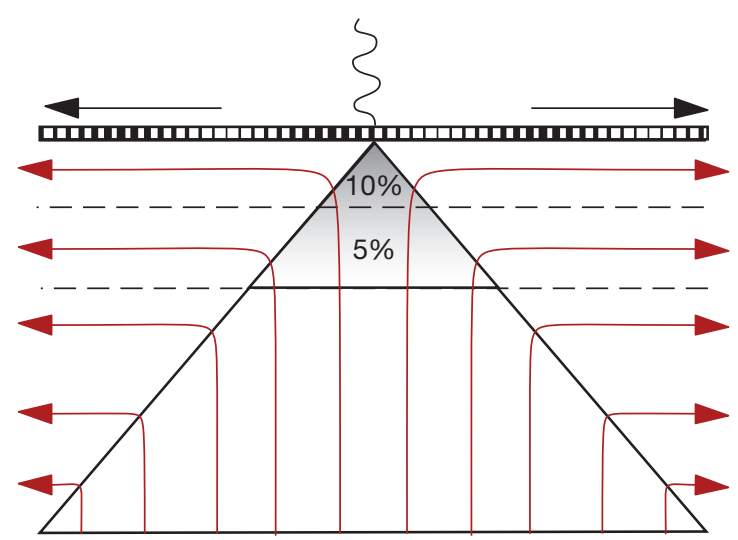

Figure 5 Steady-state passive upwelling and melting regime model beneath mid-ocean ridges. Solid red curves with arrows are mantle flow paths through the melting regime; dashed lines are contours of the extent of melting. The cartoon illustrates melting for two different mantle temperatures. (a) Hotter mantle intersects the solidus deeper (Figure 4), leading to greater extents of melting and a thicker crust; (b) Colder mantle intersects the solidus at shallower depth, leading to lesser extents of melting and a thinner crust. Modified from Plank T and Langmuir CH (1992) Effects of the melting regime on the composition of oceanic crust. Journal of Geophysical Research 97: 19749-19770.

maximum extent of melting than will colder mantle. This relationship leads to correlations between magma chemistry, axial depth, and crustal thickness, which are discussed in a subsequent section.

In reality, the mantle flow field will be more complex if the flow is not merely passive (e.g., Scott and Stevenson, 1989), and melting will be a more complex function of height. For example, Asimow et al. (2004) point out that the 1/T dependence of $(\partial S / \partial T)_{\mathrm{P}}$ leads to increased melt productivity with increasing melt fraction during batch melting. Exhaustion of phases such as clinopyroxene and garnet will also affect the rate at which melt is produced as a function of pressure. More complex mantle flow patterns, varying efficiency of melting focusing, and other factors also complicate the picture.

The homogeneity of MORB compared to basalts from other tectonic regimes suggests that, on the whole, mixing of the varied melts produced within the melting region is relatively efficient. Much of this mixing likely occurs in shallow AMCs. There is, however, some evidence that the primary melts are quite diverse, as the model in Figure 5 would suggest. There are several lines of evidence for this. The first is chemical heterogeneity between lava flows closely related in space and time and within individual lava flows (e.g., Bergmanis et al., 2007; Rubin et al., 2001, 2009). Only some of the chemical variability within individual flows can be attributed to the effects of low-pressure fractional crystallization. For example, Bergmanis et al. (2007) document correlated $\mathrm{MgO}-{ }^{206} \mathrm{~Pb} /{ }^{204} \mathrm{~Pb}$ variations in a single $<15$-year-old, $\sim 20$-km-long lava flow on the southern EPR. They attribute this to incomplete mixing of magmas in shallow, seismically imaged AMCs. Rubin et al. (2001) show that the extent of within-flow compositional heterogeneity correlates positively with flow volume on slowto fast-spreading ridges; lavas from the superfast-spreading southern EPR are, however, more homogeneous than this global trend would predict. They also found that compositional heterogeneity is inversely correlated with spreading rate: more homogeneous lavas erupted on faster spreading ridges, probably reflecting the greater thermal stability and longevity of subridge crustal magma bodies, as well as, perhaps, higher eruption frequencies.

A second line of evidence comes from studies of melt inclusions. Melt inclusions are small pockets of melt that are trapped within phenocrysts as the minerals crystallized from their host magmas. Thus, to the extent that the phenocrysts crystallized from a less evolved or less well-mixed melt, the melt inclusions record the nature of more primitive melt compositions. Studies of melt inclusions have revealed that, although they are broadly similar in major element composition to their host lavas, they tend to extend to more primitive (higher $\mathrm{MgO}$ ) compositions, suggesting that they indeed record an earlier point in the evolutionary history of the magma (e.g., Nielsen et al., 1995; Shimizu, 1998; Sinton et al., 1993; Sobolev and Shimizu, 1993; Sours-Page et al., 1999, 2002; Zhang et al., 2010). Maclennan (2008) found that melt inclusions in Icelandic lavas were more heterogeneous than whole-rock samples of the same flow. The heterogeneity of olivine melt inclusions decreased with decreasing forsterite content of the olivine, suggesting progressive homogenization of magma cooling and crystallizing in crustal magma chambers. Winpenny and Maclennan (2011) found that the range of $\mathrm{Ce} / \mathrm{Yb}$ ratios in melt inclusions required simultaneous mixing and crystallization of compositionally variable mantle melts. Also, both the mean and variance of $\mathrm{Ce} / \mathrm{Yb}$ ratios in $\mathrm{Mg}$ rich clinopyroxene melt inclusions were less than those of inclusions hosted by Mg-rich olivines. They argued that this difference could be explained if small-degree melts form at the greatest depth in the presence of garnet and consequently have high $\mathrm{Ce} / \mathrm{Yb}$ ratios. On cooling, these deep melts have long olivine-only crystallization paths and eventually crystallize Mg-poor clinopyroxene. In contrast, melts produced at shallow depth in the absence of garnet have lower $\mathrm{Ce} / \mathrm{Yb}$ ratios and shorter olivine-only crystallization paths, and saturate with Mg-rich clinopyroxene.

Near-primary melt inclusions from the FAMOUS area near $37^{\circ} \mathrm{N}$ on the MAR display major and trace element chemical trends that form the primitive continuation of the FAMOUS 
MORB suite (Laubier et al., 2007). Comparison of these trends with predicted curves for models of peridotite melting indicates that compositional variations are best reproduced by polybaric partial melting of a relatively homogeneous mantle source and subsequent mixing in various proportions of the melt batches produced at different degrees of melting and/or in different parts of the melting system. These observations suggest that transport of melts from the melting region to the site of olivine crystallization occurs without significant chemical exchange with the surrounding mantle.

Finally, lavas recovered from near-axis seamounts record a wider range of magma compositions than are erupted along the adjacent ridge, including both more depleted and more enriched compositions (e.g., Batiza and Vanko, 1984; Fornari et al., 1988; Graham et al., 1988; Hekinian et al., 1989; Karsten et al., 1990; Niu and Batiza, 1997; Reynolds et al., 1992). These findings suggest that the seamount magmas bypass the welldeveloped magma chamber system, which tends to homogenize magmas formed from a heterogeneous source and through a range of melting conditions. This effect also appears to play a role in explaining the diversity of melt compositions recovered from intratransform eruptions (e.g., Natland, 1989; Saal et al., 2008; Wendt et al., 1999).

\subsubsection{Melt Extraction and Flow}

Melting in peridotite begins at points where three or more different kinds of mineral grains touch, because, on the mineral grain scale, it is only at these grain junctions where the minimum melting composition occurs. As melt fraction increases, the melt will eventually spread along grain edges, forming an interconnected network (e.g., Zhu et al., 2011). Once melt fraction reaches $0.02-3 \%$, depending on interfacial free energies, permeability increases rapidly and the melt will be expelled upward by a combination of buoyancy, melting rate, and compaction (Von Bargen and Waff, 1986; Wark et al., 2003; Zhu et al., 2011). Melt may initially segregate into horizontal melt-rich horizons or sills deep within the melting region (Rabinowicz and Toplis, 2009). Depending on mantle viscosity, these sills may then rise as compaction waves, or rotate and form a set of vertically oriented melt-rich veins or finger-like channels (Rabinowicz and Toplis, 2009; Spiegelman and Kelemen, 2003). Several lines of evidence suggest that melt transport through the uppermost mantle is indeed through such vertically oriented melt-rich channels. The first is that basalts generally, and MORB in particular, are not in equilibrium with residual peridotites from the uppermost mantle (e.g., O'Hara, 1968). The second observation is the diversity of melt inclusion compositions mentioned above. A third line of evidence is the abundant dunite veins and channels observed in mantle sections of ophiolites, apparently produced as melt-rock reaction results in dissolution of orthopyroxene and precipitation of olivine (e.g., Kelemen and Dick, 1995; Kelemen et al., 1995). At depths greater than 20 km, these melt channels may be harzburgite or lherzolite (Liang et al., 2010). Spiegelman and Kelemen (2003) found that these channel systems could produce significant compositional diversity, even from a homogeneous source in complete chemical equilibrium, because channelization can transpose the chemical variability produced by melting throughout the melting column into horizontal variability across the width of the channel. The centers of channels contain trace elementenriched melts from depth, while the edges of the channels transport highly depleted melts extracted from the interchannel regions at shallower levels. Hewitt and Fowler (2009) suggest that the vast majority of melt could be expected to eventually flow into these channels, where the ascent velocity would be on the order of $100 \mathrm{~m} \mathrm{year}^{-1}$, leaving the residual matrix with melt fractions of $<0.5 \%$. On the other hand, Jull et al. (2002) concluded that disequilibrium among U-decay series isotopes is best explained if $\sim 60 \%$ of the melt travels to the surface slowly via porous flow, and the remainder travels more rapidly through these high-porosity channels. The constraints imposed on melt segregation and flow by U-decay series isotopes are discussed in greater detail in Chapter 4.15.

\subsubsection{Crystallization}

As mantle rises toward the surface, it eventually encounters a conductive cooling regime where temperatures decrease more rapidly than adiabatic. At that point, which represents $P_{\mathrm{f}}$ melting ceases and the melts, which are never superheated (i.e., they were always just saturated with at least one mantle phase), begin to crystallize. Because the composition of the phase or phases initially crystallizing is different from that of the bulk liquid composition, the liquid composition evolves through fractional crystallization. At least since the work of $\mathrm{O}^{\prime}$ Hara (1968), it has been understood that essentially all basalts at mid-ocean ridges have experienced some extent of fractional crystallization.

The crystallization process is now reasonably well understood, at least in comparison to the melt generation process. This understanding is based on nearly a century of work dating back to Bowen (1928). Significant advances have been made in the last two decades as thermodynamics-based computer programs, such as MELTS (Ghiorso and Sack, 1995; Ghiorso et al., 2002) and PETROLOG (Danyushevsky, 2001; Danyushevsky and Plechov, 2011), calibrated from abundant laboratory experiments and petrological observations, make it possible to numerically simulate the chemical evolution of liquids undergoing fractional crystallization with some success.

Much of this crystallization occurs at relatively low pressure within the oceanic crust. Figure 6 shows an example of chemical variations in recent lava flows from the $9^{\circ} 37^{\prime} \mathrm{N}$ area of the EPR (Smith et al., 2001). The variation in major elements is well modeled with the MELTS simulation of low-pressure (0.1 GPa) fractional crystallization of olivine, plagioclase, and clinopyroxene, assuming the presence of small amounts of water $(0.05-0.2 \mathrm{wt} \%)$. These pressures correspond well with the depth of the seismically imaged $\mathrm{AMC}$ in this area.

Yet not all chemical variation in MORB is so readily explained by low-pressure fractionation of observable phenocryst phases. In many instances, MORB magmas appear to have evolved through crystallization of significantly greater amounts of clinopyroxene than would be expected to occur at low pressure (e.g., Fisk et al., 1980; Flower, 1980). Laboratory experiments have demonstrated that the range of compositions where clinopyroxene is a stable liquidus phase expand with increasing pressure, implying that crystallization may 

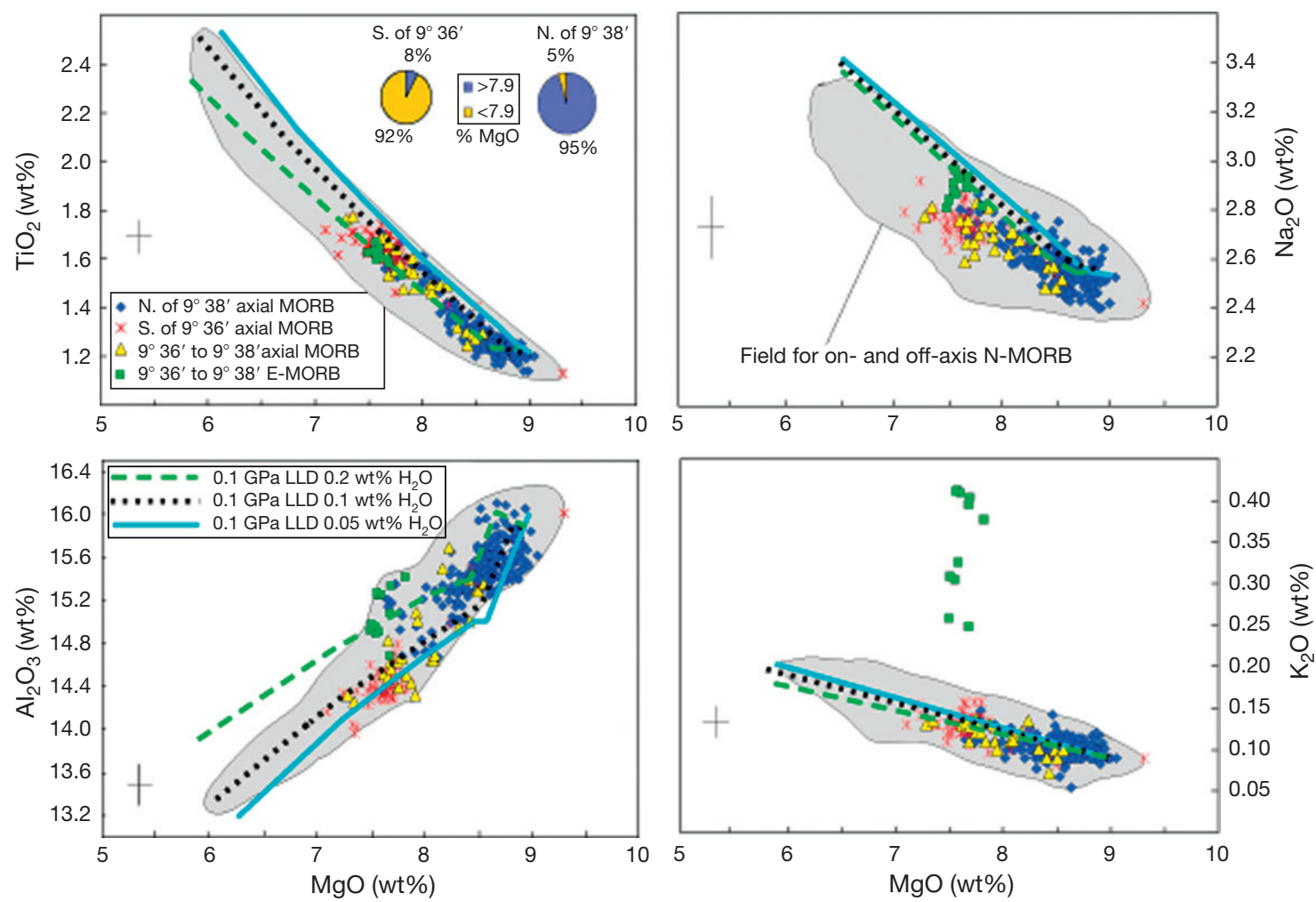

Figure 6 Correlation of $\mathrm{TiO}_{2}, \mathrm{Na}_{2} \mathrm{O}, \mathrm{Al}_{2} \mathrm{O}_{3}$, and $\mathrm{K}_{2} \mathrm{O}$ with $\mathrm{MgO}$ for MORB recovered by submersible near $9^{\circ} 37^{\prime} \mathrm{N}$ on the EPR. Field denotes compositional range for all rock core or submersible samples from the EPR. Crossed lines indicating $\pm 2 \sigma$ errors are shown and indicate approximately $\pm 2 \%$ of $\mathrm{MgO}$ and $\mathrm{Al}_{2} \mathrm{O}_{3}, \pm 4 \%$ of $\mathrm{TiO}_{2}, \pm 5 \%$ of $\mathrm{Na}_{2} \mathrm{O}$, and $\pm 15 \%$ of $\mathrm{K}_{2} \mathrm{O}$. Colored lines represent liquid lines of descent calculated using MELTS for parents with 0.05 (blue solid line), 0.1 (black short dashed line), and 0.2 (green long dashed line) wt $\% \mathrm{H}_{2} \mathrm{O}$ (see text for details of models). Pie diagrams in upper right show relative percentages of samples with less than (yellow) and greater than (blue) $7.9 \mathrm{wt} \% \mathrm{Mg0}$. Reproduced from Smith MC, Perfit MR, Fornari DJ, et al. (2001) Magmatic processes and segmentation at a fast spreading mid-ocean ridge: Detailed investigation of an axial discontinuity on the East Pacific Rise crest at 9`37' N. Geochemistry, Geophysics, Geosystems 2. http://dx.doi.org/10.1016/B978-0-08-09575-7.00315-6.

begin at greater depth, well before magmas reach crustal magma chambers (e.g., Grove et al., 1992). The pressure dependence of clinopyroxene saturation has been parameterized by Herzberg (2004) and Villiger et al. (2007) in a way that allows calculation of the pressure of crystallization. Herzberg (2004) and Villiger et al. (2007) concluded that crystallization may begin at pressures as high as $1 \mathrm{GPa}$, which corresponds to a depth of roughly $30 \mathrm{~km}$. Consistent with earlier conclusions of Michael and Cornell (1998), they found that the dominant pressure of crystallization is related inversely to the spreading rate and magma supply. This suggests that at fast-spreading ridges, and slow-spreading ridges with robust magma supply, such as the Reykjanes Ridges, crystallization occurs primarily within the crust, while at slow-spreading ridges with typical magma supply and in the vicinity of fracture zones, crystallization within the mantle dominates. Crystallization is also deeper in the vicinity of fracture zones. These effects may result from the fact that when melt supply is low, it may be difficult for magmas to reach shallow crustal levels and they may therefore crystallize deeper (Rubin and Sinton, 2007). However, Lissenberg and Dick (2008) found that Mg-rich clinopyroxene can form through melt-rock reaction within the lower crust and that these reactions mimic the effect of high-pressure clinopyroxene fractionation. Thus, they argue that the calculated pressures of MORB fractionation may be overestimated.
Since, as noted above, the beginning of crystallization coincides with the end of melting, these results imply that $P_{\mathrm{f}}$ varies with spreading rate and magma supply. Thus, for a given mantle temperature, melting will cease at greater depth, resulting in lower $F_{\max }$ and $\bar{F}$ and higher $\bar{P}$ for slow-spreading ridges compared to fast-spreading ones.

Although crystallization appears to begin at greater depth at slow-spreading ridges, the amount of fractional crystallization is generally greater at fast-spreading ridges. A good measure of the extent of fractional crystallization experienced by basaltic magmas is the $\mathrm{Mg}$ number (molar ratio of magnesium to magnesium plus ferrous iron, i.e., $\mathrm{Mg} \#=100 \times[\mathrm{Mg}] /([\mathrm{Mg}]+$ $\left.\left[\mathrm{Fe}^{2+}\right]\right)$. For reference, magma in equilibrium with mantle peridotite should have an Mg number of 70-72 (Roeder and Emslie, 1970). Sinton and Detrick (1992) found that the mean $\mathrm{Mg}$ number of basalts erupted along ridges with full spreading rates less than $5 \mathrm{~cm}_{\text {year }}{ }^{-1}$ was 57.1 and that this decreased to 52.8 for fast-spreading ridges $\left(>8 \mathrm{~cm}_{\text {year }}{ }^{-1}\right)$. They found no difference in mean $\mathrm{Mg}$ number between intermediate- and fastspreading ridges, and no decrease in $\mathrm{Mg}$ number with spreading rates above $8 \mathrm{~cm}_{\text {year }}{ }^{-1}$. Rubin and Sinton (2007), using a much more extensive dataset, demonstrate a more or less linear decrease in $\mathrm{Mg}$ number with spreading rate through the entire range (Figure 7). The corresponding decrease in $\mathrm{MgO}$ concentration suggests that lavas at the slowest spreading ridges erupt 


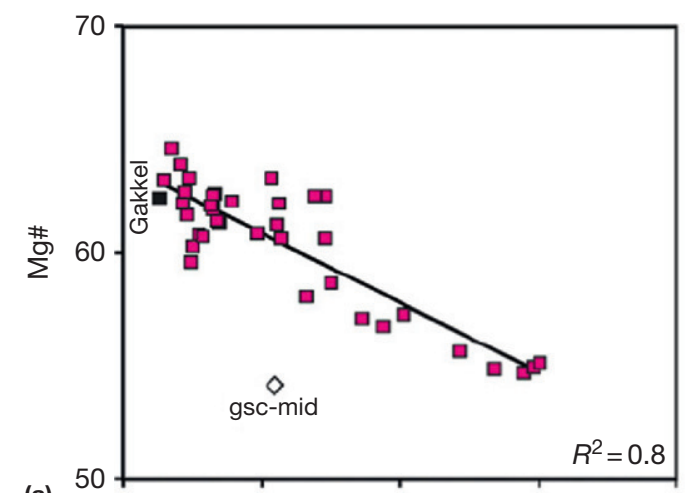

(a)

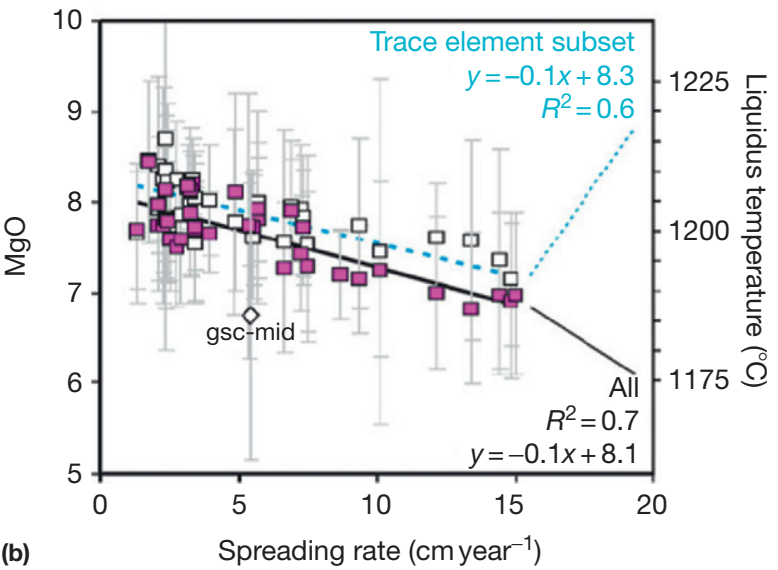

Figure 7 Regional averages of $\mathrm{MgO}$ and $\mathrm{Mg \#}$ from $>11000 \mathrm{MORB}$ samples display strong linear relationships with spreading rate (Gakkel datum in panel (a) estimated from Michael et al., 2003). Panel (b) also shows mean $\mathrm{MgO}$ for both the entire $>11000$ sample suite (solid symbols) and the 2100 sample glass/whole rock subset for which trace element and isotopic data also exist (open symbols). The same inverse correlation is observed in both. Reproduced from Rubin KH and Sinton JM (2007) Inferences on mid-ocean ridge thermal and magmatic structure from MORB compositions. Earth and Planetary Science Letters 260: 257-276.

roughly $20^{\circ} \mathrm{C}$ hotter than at the fastest spreading ones. The greater extent of crystallization and lower eruption temperatures of MORB from fast-spreading ridges than from slow-spreading ones is likely a direct consequence of the crystallization occurring primarily at shallower depths, as discussed above.

\subsubsection{The Composition of MORB}

\subsubsection{The Average Composition of MORB}

\subsection{Major elements}

The average composition of MORB, calculated from 2010 complete whole rock analyses in PetDB (a MORB database available at http://www.petdb.org/), is listed in Table 1. As has been known for 50 years, MORB are predominately hypersthene-normative tholeiites of comparatively uniform composition (e.g., Engel et al., 1965; Muir and Tilley, 1964). Compared to tholeiitic basalts from other tectonic environments, MORB are, on average, poorer in $\mathrm{K}_{2} \mathrm{O}$, $\mathrm{TiO}_{2}$, and $\mathrm{FeO}$. $\mathrm{K}$ and $\mathrm{Ti}$ are incompatible elements, and their low concentrations are consistent with the general incompatible element-poor nature of MORB discussed below. The low FeO concentrations reflect their generation at shallower depth than basalts from other environments (Klein and Langmuir, 1987; Langmuir et al., 1992).

Also listed are the mean values for basalts from the three ocean basins; although there are some differences, comparison between averages from different ocean basins only serves to highlight the remarkable uniformity of MORB major element compositions in comparison to those of basalts from other tectonic environments. Pacific MORB tend to have slightly lower $\mathrm{Mg}$ numbers than MORB from the Indian and the Atlantic oceans, which likely reflects the higher spreading rates of Pacific spreading centers and the relationship between fractionation and spreading rate discussed in the previous section. $\mathrm{SiO}_{2}, \mathrm{MnO}$, and $\mathrm{CaO}$ concentrations are nearly identical in MORB from all ocean basins. There are, however, subtle differences in the other major oxides, the likely causes of which will be discussed below. MORB magmas erupt against cold seawater, chilling the outer molten margins to glass, which provides a convenient sample of the liquid phase of the lava. The average glass composition, also listed in Table 1, is slightly more fractionated than the average whole-rock composition, as might be expected since the whole-rock composition will contain crystals in addition to melt.

\subsection{Trace elements}

Table 2 lists the mean, log-normal mean, and standard deviations of concentrations of 30 incompatible trace elements in MORB based on a compilation of 1975 analyses from PetDB and recent literature that have been filtered for data quality. Table 3 lists these values for the three ocean basins. Means are computed as

$$
\text { Mean }=\sum_{i=1}^{n} X_{i}
$$

where $X$ is the concentration and $n$ is the number of observations. Log-normal means are computed as

$$
\text { Log-normal mean }=10^{\sum_{i=1}^{n} \log \left(X_{i}\right) / n}
$$

The value of the log-normal mean was explained by Arevalo and McDonough (2010). Unlike the major elements, incompatible element concentrations in MORB can be highly variable. $\mathrm{Ba}$, one of the most incompatible elements, varies by a factor of 660; Lu, which is only moderately incompatible, varies by a factor of 24. Variability is also illustrated by the standard deviations, particularly when compared to major elements. The more abundant major elements have standard deviations that are $17 \%$ or less of the mean value; the variability of incompatible trace elements ranges from $45 \%$ to more than $100 \%$ of the mean value. As Arevalo and McDonough (2010) pointed out, this results in incompatible element concentrations that are highly skewed and quite non-Gaussian. Mean values are consequently different from the mode and median values, and do not characterize the population well. As Arevalo and McDonough show, converting the concentration to a logarithm produces a Gaussian distribution. Thus, the lognormal means characterize typical concentrations. The mean value is nonetheless useful when, for example, one wishes to 
Table 1 Major element chemistry of mid-ocean ridge basalts

\begin{tabular}{|c|c|c|c|c|c|c|c|c|c|c|c|c|c|}
\hline & \multicolumn{5}{|c|}{ All whole rocks } & \multicolumn{2}{|l|}{ Atlantic } & \multicolumn{2}{|l|}{ Indian } & \multicolumn{2}{|l|}{ Pacific } & \multirow{2}{*}{$\begin{array}{l}\text { Glasses } \\
\text { Mean }\end{array}$} & \multirow{2}{*}{$\begin{array}{l}\text { Arevalo and } \\
\text { McDonough } \\
\text { Mean }\end{array}$} \\
\hline & Mean & Median & Mode & $\sigma$ & $\% \sigma$ & Mean & $\sigma$ & Mean & $\sigma$ & Mean & $\sigma$ & & \\
\hline $\mathrm{SiO}_{2}$ & 50.06 & 50.06 & 49.90 & 1.13 & 2.3 & 50.04 & 0.75 & 49.93 & 0.89 & 50.10 & 1.42 & 50.60 & 50.57 \\
\hline $\mathrm{TiO}_{2}$ & 1.52 & 1.50 & 1.54 & 0.43 & 28.5 & 1.33 & 0.34 & 1.41 & 0.50 & 1.71 & 0.42 & 1.67 & 1.46 \\
\hline $\mathrm{Al}_{2} \mathrm{O}_{3}$ & 15.00 & 14.83 & 14.40 & 1.25 & 8.3 & 15.20 & 1.08 & 16.03 & 1.34 & 14.63 & 1.24 & 14.79 & 15.51 \\
\hline $\mathrm{FeO}_{\mathrm{T}}$ & 10.36 & 10.31 & 9.59 & 1.57 & 15.1 & 10.18 & 1.36 & 9.10 & 1.53 & 10.74 & 1.61 & 10.46 & 9.50 \\
\hline $\mathrm{MnO}$ & 0.19 & 0.18 & 0.19 & 0.03 & 14.4 & 0.18 & 0.02 & 0.17 & 0.03 & 0.19 & 0.03 & 0.19 & 0.16 \\
\hline $\mathrm{MgO}$ & 7.71 & 7.66 & 7.24 & 1.31 & 17.0 & 7.98 & 1.14 & 7.83 & 1.25 & 7.45 & 1.41 & 7.42 & 7.69 \\
\hline $\mathrm{CaO}$ & 11.46 & 11.57 & 11.50 & 0.91 & 8.0 & 11.59 & 0.78 & 11.24 & 0.98 & 11.37 & 1.00 & 11.38 & 11.39 \\
\hline $\mathrm{Na}_{2} \mathrm{O}$ & 2.52 & 2.54 & 2.47 & 0.41 & 16.4 & 2.37 & 0.40 & 2.86 & 0.63 & 2.61 & 0.31 & 2.77 & 2.74 \\
\hline $\mathrm{K}_{2} \mathrm{O}$ & 0.19 & 0.14 & 0.06 & 0.18 & 96.3 & 0.19 & 0.18 & 0.35 & 0.31 & 0.16 & 0.14 & 0.19 & 0.18 \\
\hline $\mathrm{P}_{2} \mathrm{O}_{5}$ & 0.16 & 0.15 & 0.15 & 0.08 & 52.6 & 0.14 & 0.06 & 0.18 & 0.11 & 0.18 & 0.10 & 0.18 & 0.15 \\
\hline $\mathrm{H}_{2} \mathrm{O}$ & 0.45 & 0.39 & 0.25 & 0.26 & 58.0 & 0.46 & 0.26 & 0.57 & 0.19 & 0.40 & 0.29 & - & - \\
\hline Mg\# & 59 & 60 & 56 & 7 & 11.5 & 61 & & 63 & 6 & 58 & 8 & 58 & 59 \\
\hline \multirow[t]{2}{*}{ Number } & 2010 & & & & & 877 & & 152 & & 967 & & 3129 & 712 \\
\hline & \multicolumn{5}{|c|}{ CIPW norms } & & & & & & & & \\
\hline Anorthite & \multicolumn{5}{|c|}{28.53} & \multicolumn{2}{|l|}{29.81} & \multicolumn{2}{|l|}{29.33} & \multicolumn{2}{|l|}{27.21} & 26.70 & 28.90 \\
\hline Albite & \multicolumn{5}{|l|}{27.68} & 29.02 & & \multicolumn{2}{|l|}{24.49} & \multicolumn{2}{|l|}{26.99} & 25.70 & 25.70 \\
\hline Plagioclase & \multicolumn{5}{|l|}{50.76} & 50.67 & & \multicolumn{2}{|l|}{54.50} & \multicolumn{2}{|l|}{50.20} & 50.95 & 52.93 \\
\hline Orthoclase & \multicolumn{5}{|l|}{1.12} & 1.12 & & \multicolumn{2}{|l|}{2.07} & \multicolumn{2}{|l|}{0.95} & 1.12 & 1.06 \\
\hline Diopside & \multicolumn{5}{|l|}{22.06} & 21.64 & & \multicolumn{2}{|l|}{20.29} & \multicolumn{2}{|l|}{22.75} & 22.95 & 21.36 \\
\hline Hypersthene & \multicolumn{5}{|l|}{16.89} & 18.00 & & \multicolumn{2}{|l|}{9.16} & \multicolumn{2}{|l|}{17.30} & 15.57 & 15.53 \\
\hline Olivine & \multicolumn{5}{|l|}{4.21} & 4.03 & & \multicolumn{2}{|l|}{9.37} & 3.37 & & 4.15 & 4.43 \\
\hline Ilmenite & 2.91 & & & & & 2.54 & & 2.70 & & 3.29 & & 3.17 & 2.79 \\
\hline Magnetite & 1.68 & & & & & 1.65 & & 1.48 & & 1.74 & & 1.70 & 1.54 \\
\hline Apatite & 0.37 & & & & & 0.32 & & 0.42 & & 0.42 & & 0.42 & 0.35 \\
\hline
\end{tabular}

calculate the total mass of an element in a reservoir as, for example, the mass of La in the volcanic layer of the oceanic crust would be calculated as the mass of the layer multiplied by the mean, as opposed to median or log-normal mean, La concentration.

Average values from a recent compilation by Arevalo and McDonough (2010), as well as older estimates of average MORB composition, are also listed in Table 2. The global average given here agrees within $10 \%$ for all elements with the Arevalo and McDonough values, except for $\mathrm{Ba}, \mathrm{Ta}, \mathrm{U}$, and Th, for which the Arevalo and McDonough values are $14-22 \%$ lower.

In addition to a global MORB average, Table 2 also lists values for $\mathrm{N}$-MORB (so-called normal MORB) averages. MORB have long been recognized as being depleted in incompatible elements compared to more compatible ones, and this is reflected in the average values shown in Table 2 . Thus, for example, average MORB is depleted in light rare earths compared to heavy rare earths in all estimates (e.g., Figure 8). However, some MORB show light rare earth enrichments (E-MORB), with $(\mathrm{La} / \mathrm{Sm})_{\mathrm{N}}$ (i.e., chondrite-normalized La/Sm) greater than 1. Many of these E-MORB come from ridge segments adjacent to oceanic islands, such as Iceland, the Azores, and the Galapagos. The less incompatible element-depleted nature of such samples is generally thought to reflect a mantle plume contribution to their sources. E-MORB also occur less commonly and often off-axis at ridge segments uninfluenced by plumes, with a frequency estimated to be in the range of 3-10\% (Donnelly et al., 2004; Langmuir et al., 1986; Smith et al., 2001; Waters et al., 2011); these likely reflect smaller heterogeneities dispersed in the mantle. Waters et al. (2011) concluded that E-MORB in the $9-10^{\circ} \mathrm{N}$ region of the EPR erupt through the same plumbing system as other lavas, but are preserved only off-axis simply because of their small proportions relative to the volumetrically and volcanically dominant N-MORB.

The term N-MORB was originally introduced by Schilling (1975) to refer to MORB uninfluenced by mantle plumes, but the definition has evolved over the years to refer to incompatible element-depleted MORB, regardless of their location. Here, we adopt the definition of Arevalo and McDonough, namely that N-MORB are those MORB with $(\mathrm{La} / \mathrm{Sm})_{\mathrm{N}}<1$. By this definition, $70 \%$ of MORB samples in PetDB are classified as N-MORB. N-MORB are least abundant (64\%) in the Atlantic, where relatively large areas of the MAR are influenced by mantle plumes, and are most abundant along Pacific ridges (86\%), where hotspots tend to be more distant from spreading centers and plume influences are more localized.

A problem in studying average global systematics in MORB trace elements is that most studies report concentrations of only some elements. For example, of the 1976 analyses used in this study, 1709 reported La concentrations, 1421 reported U concentrations, 725 reported Tm concentrations, and 208 reported $\mathrm{K}$ concentrations. This can lead to problems in computing elemental ratios. For example, the ratio of global mean $\mathrm{K}$ to mean $\mathrm{U}$ in Table 2 is 10384 . However, the average $\mathrm{K} / \mathrm{U}$ value for samples in this dataset analyzed for both $\mathrm{K}$ and $\mathrm{U}$ is 16574. Thus, because many analyses are incomplete, average values in Table 2 should not be used to compute trace element ratios. Values of commonly used trace element ratios, 
Table 2 Average trace element concentrations ( $\mathrm{ppm})$ in mid-ocean ridge basalts

\begin{tabular}{|c|c|c|c|c|c|c|c|c|c|c|c|}
\hline & \multicolumn{4}{|l|}{ Global } & \multicolumn{4}{|l|}{$N-M O R B$} & \multirow{2}{*}{$\begin{array}{l}\text { LN mean (Arevalo } \\
\text { and McDonough, } \\
\text { 2010) }\end{array}$} & \multirow{2}{*}{$\begin{array}{l}\text { N-MORB (Sun and } \\
\text { McDonough, } \\
\text { 1989) }\end{array}$} & \multirow{2}{*}{$\begin{array}{l}\text { N-MORB } \\
\text { (Hofmann, 1988) }\end{array}$} \\
\hline & Mean & LN mean & $\sigma$ & $n$ & $L N$ mean & mean & $\sigma$ & $n$ & & & \\
\hline $\mathrm{Li}$ & 6.63 & 6.39 & 2.07 & 399 & 6.38 & 6.64 & 2.19 & 249 & & & \\
\hline $\mathrm{Be}$ & 0.64 & 0.55 & 0.40 & 358 & 0.45 & 0.50 & 0.28 & 231 & & & \\
\hline B & 1.80 & 1.62 & 0.80 & 259 & 1.38 & 1.53 & 0.62 & 150 & & & \\
\hline K & 1237 & 932 & 1179 & 203 & 731 & 857 & 536 & 147 & 1620 & 600 & 884 \\
\hline Sc & 36.8 & 36.4 & 5.00 & 507 & 38.1 & 38.3 & 4.0 & 377 & & & \\
\hline V & 299 & 290 & 63.9 & 685 & 308 & 314 & 55.3 & 468 & & & \\
\hline $\mathrm{Cr}$ & 331 & 314 & 87.9 & 170 & 318 & 334 & 84.4 & 158 & & & \\
\hline Co & 43.7 & 43.2 & 6.25 & 332 & 43.6 & 43.9 & 5.4 & 224 & & & \\
\hline $\mathrm{Ni}$ & 100 & 89.8 & 49.5 & 773 & 95.6 & 104 & 49.8 & 519 & & & \\
\hline $\mathrm{Cu}$ & 80.8 & 77.4 & 24.7 & 408 & 79.0 & 82.0 & 23.3 & 314 & & & \\
\hline $\mathrm{Zn}$ & 86.8 & 84.3 & 21.0 & 452 & 85.8 & 88.0 & 20.1 & 345 & & & \\
\hline $\mathrm{Rb}$ & 4.05 & 2.10 & 5.12 & 1265 & 1.06 & 1.36 & 1.07 & 791 & & 0.56 & 1.26 \\
\hline $\mathrm{Sr}$ & 138 & 126 & 68.3 & 1668 & 107 & 110 & 28.0 & 1152 & 130 & 90 & 113 \\
\hline$Y$ & 32.4 & 30.9 & 13.1 & 1530 & 30.7 & 32.2 & 10.9 & 1072 & 30 & 28 & 35.8 \\
\hline $\mathrm{Zr}$ & 103 & 92.1 & 60.3 & 1530 & 88.3 & 88.8 & 40.4 & 1075 & 90.1 & 74 & 104 \\
\hline $\mathrm{Nb}$ & 6.44 & 3.82 & 7.98 & 1450 & 2.33 & 2.8 & 1.88 & 1026 & 3.44 & 2.33 & 3.51 \\
\hline Cs & 0.053 & 0.029 & 0.06 & 588 & 0.015 & 0.019 & 0.02 & 371 & & 0.007 & 0.014 \\
\hline $\mathrm{Ba}$ & 43.4 & 21.3 & 59.3 & 1584 & 11.3 & 14.7 & 11.5 & 1051 & 16.60 & 6.3 & 13.9 \\
\hline $\mathrm{La}$ & 4.87 & 3.68 & 4.78 & 824 & 2.98 & 3.39 & 1.98 & 643 & 3.77 & 2.5 & 3.9 \\
\hline $\mathrm{Ce}$ & 13.1 & 10.7 & 10.8 & 824 & 9.13 & 10.2 & 5.72 & 643 & 11.50 & 7.5 & 12 \\
\hline $\mathrm{Pr}$ & 2.08 & 1.76 & 1.52 & 823 & 1.56 & 1.74 & 0.94 & 643 & 1.91 & 1.32 & 2.07 \\
\hline $\mathrm{Nd}$ & 10.4 & 9.20 & 6.39 & 824 & 8.48 & 9.22 & 4.47 & 643 & 9.80 & 7.3 & 11.2 \\
\hline $\mathrm{Sm}$ & 3.37 & 3.10 & 1.69 & 824 & 2.99 & 3.19 & 1.35 & 643 & 3.25 & 2.63 & 3.75 \\
\hline Eu & 1.20 & 1.14 & 0.45 & 824 & 1.11 & 1.15 & 0.38 & 643 & 1.22 & 1.02 & 1.34 \\
\hline $\mathrm{Gd}$ & 4.42 & 4.11 & 2.02 & 775 & 4.05 & 4.29 & 1.72 & 604 & 4.40 & 3.68 & 5.08 \\
\hline $\mathrm{Tb}$ & 0.81 & 0.76 & 0.44 & 818 & 0.76 & 0.81 & 0.45 & 638 & 0.78 & 0.67 & 0.89 \\
\hline Dy & 5.28 & 4.99 & 2.16 & 815 & 5.05 & 5.27 & 1.84 & 634 & 5.11 & 4.55 & 6.3 \\
\hline $\mathrm{Ho}$ & 1.14 & 1.08 & 0.46 & 824 & 1.10 & 1.14 & 0.39 & 643 & 1.11 & 1.01 & 1.34 \\
\hline $\mathrm{Er}$ & 3.30 & 3.11 & 1.38 & 823 & 3.18 & 3.31 & 1.16 & 642 & 3.15 & 2.97 & 4.14 \\
\hline $\mathrm{Tm}$ & 0.49 & 0.45 & 0.22 & 702 & 0.47 & 0.49 & 0.18 & 536 & 0.48 & 0.46 & 0.62 \\
\hline $\mathrm{Yb}$ & 3.17 & 2.99 & 1.35 & 824 & 3.07 & 3.20 & 1.10 & 643 & 3.00 & 3.05 & 3.9 \\
\hline Lu & 0.48 & 0.45 & 0.21 & 815 & 0.47 & 0.49 & 0.17 & 635 & 0.45 & 0.455 & 0.589 \\
\hline $\mathrm{Hf}$ & 2.62 & 2.38 & 1.40 & 1160 & 2.20 & 2.36 & 1.09 & 855 & 2.4 & 2.05 & 2.97 \\
\hline $\mathrm{Ta}$ & 0.417 & 0.262 & 0.48 & 1114 & 0.161 & 0.191 & 0.13 & 763 & 0.224 & 0.13 & 0.192 \\
\hline W & 0.043 & 0.027 & 0.06 & 94 & 0.021 & 0.026 & 0.02 & 77 & & & \\
\hline $\mathrm{Pb}$ & 0.657 & 0.550 & 0.44 & 1255 & 0.419 & 0.460 & 0.20 & 812 & 0.57 & 0.3 & 0.489 \\
\hline Th & 0.491 & 0.269 & 0.65 & 1458 & 0.148 & 0.186 & 0.14 & 919 & 0.219 & 0.120 & 0.187 \\
\hline U & 0.157 & 0.094 & 0.24 & 1415 & 0.060 & 0.068 & 0.05 & 879 & 0.080 & 0.047 & 0.071 \\
\hline
\end{tabular}

"Global" refers to all data from the PetDB database as described in text; "LN mean" refers to the log-normal mean calculated as described in the text.

computed from only those analyses that include both elements, are listed in Table 4.

Incomplete analyses can also lead to problems in rare-earth patterns. For example, average rare-earth patterns reported by Arevalo and McDonough (2010) exhibit slight negative anomalies in the monoisotopic rare earths, namely, Pr, Tb, Ho, Tm. These apparent anomalies arise because concentrations of the monoisotopic rare earths are less often reported and mean rare-earth concentrations calculated by Arevalo and McDonough (2010) appear to reflect a sampling bias where, particularly among the Atlantic MORB, samples with overall lower rare-earth concentrations were more often analyzed for the monoisotopic rare earths. Because of this problem, average rare-earth concentrations in this work were estimated using only those samples for which concentrations of at least 12 of the 14 rare earths were reported.
Figure 8 compares chondrite-normalized rare-earth patterns of global average MORB, global average N-MORB, and average MORB from the three ocean basins. All exhibit light rare-earth depletion. The Pacific MORB average exhibits the greatest light rare-earth depletion $\left((\mathrm{La} / \mathrm{Sm})_{\mathrm{N}}=0.69\right)$, followed by the Atlantic $\left((\mathrm{La} / \mathrm{Sm})_{\mathrm{N}}=0.73\right)$ and the Indian $((\mathrm{La} /$ $\left.\mathrm{Sm})_{\mathrm{N}}=0.85\right)$ MORB. Overall, rare-earth abundances are greatest in the Atlantic and lowest in the Indian MORB. The Atlantic and Pacific averages exhibit small negative Eu anomalies of 3\% and $4 \%$, respectively, and this is reflected in a $3 \%$ negative Eu anomaly in the patterns of the global mean and global $\mathrm{N}-\mathrm{MORB}$ means. Indian Ocean MORB show no Eu anomaly, on average. This observation contrasts with that of Arevalo and McDonough (2010), who found that the Eu anomaly in global average MORB was less than $1 \%$. Since plagioclase is a common phenocryst in MORB, it seems likely that negative Eu 
Average trace element concentrations by ocean basin

\begin{tabular}{|c|c|c|c|c|c|c|c|c|c|c|c|c|}
\hline & \multicolumn{4}{|c|}{ Atlantic } & \multicolumn{4}{|l|}{ Pacific } & \multicolumn{4}{|l|}{ Indian } \\
\hline & Mean & LN mean & $\sigma$ & $\mathrm{n}$ & Mean & LN mean & $\sigma$ & $n$ & Mean & LN mean & $\sigma$ & $\mathrm{n}$ \\
\hline $\mathrm{Li}$ & 6.28 & 6.13 & 1.31 & 299 & 8.36 & 7.75 & 3.81 & 59 & 6.71 & 6.51 & 1.92 & 41 \\
\hline $\mathrm{Be}$ & 0.607 & 0.533 & 0.33 & 282 & 0.76 & 0.68 & 0.43 & 41 & 0.785 & 0.534 & 0.711 & 35 \\
\hline$B$ & 1.82 & 1.64 & 0.78 & 224 & & & & 0 & 1.66 & 1.44 & 0.90 & 35 \\
\hline K & 1537 & 1100 & 1628 & 71 & 1102 & 886 & 810 & 104 & 982 & 737 & 809 & 28 \\
\hline V & 295 & 291 & 46.8 & 399 & 324 & 307 & 82.9 & 197 & 261 & 254 & 59.6 & 88 \\
\hline $\mathrm{Cr}$ & 341 & 324 & 106 & 56 & 315 & 291 & 89.5 & 66 & 341 & 337 & 54.1 & 48 \\
\hline Co & 46.4 & 46.1 & 5.2 & 96 & 43.3 & 42.6 & 7.06 & 144 & 41.42 & 41.2 & 4.63 & 91 \\
\hline $\mathrm{Ni}$ & 104 & 97.2 & 38.5 & 448 & 85.7 & 70.3 & 67.4 & 219 & 114.4 & 107 & 40.0 & 105 \\
\hline $\mathrm{Cu}$ & 92.4 & 89.2 & 24.9 & 205 & 70.6 & 69.4 & 15.1 & 100 & 67.5 & 65.0 & 20.7 & 102 \\
\hline $\mathrm{Zn}$ & 83.2 & 81.2 & 17.2 & 207 & 100 & 98.3 & 21.8 & 148 & 73.8 & 72.5 & 15.1 & 96 \\
\hline $\mathrm{Rb}$ & 4.39 & 2.29 & 5.16 & 816 & 2.80 & 1.53 & 3.77 & 231 & 4.11 & 2.12 & 5.93 & 218 \\
\hline$Y$ & 30.1 & 29.3 & 7.03 & 806 & 38.5 & 35.6 & 20.6 & 433 & 29.5 & 28.6 & 7.95 & 287 \\
\hline $\mathrm{Zr}$ & 93.9 & 86.2 & 39.5 & 794 & 118 & 104 & 82.5 & 460 & 100 & 90.0 & 57.4 & 272 \\
\hline $\mathrm{Nb}$ & 6.83 & 4.07 & 7.72 & 773 & 5.43 & 3.38 & 7.15 & 399 & 6.82 & 3.90 & 9.51 & 278 \\
\hline Cs & 0.048 & 0.025 & 0.059 & 419 & 0.06 & 0.04 & 0.05 & 96 & 0.07 & 0.04 & 0.08 & 73 \\
\hline $\mathrm{Ba}$ & 50.1 & 24.5 & 62.5 & 855 & 25.8 & 14.6 & 35.3 & 399 & 44.4 & 22.5 & 63.4 & 326 \\
\hline $\mathrm{La}$ & 5.73 & 4.24 & 5.04 & 892 & 5.28 & 4.10 & 5.12 & 462 & 5.43 & 4.09 & 5.62 & 345 \\
\hline $\mathrm{Ce}$ & 14.6 & 11.8 & 10.5 & 831 & 14.8 & 12.4 & 12.0 & 489 & 14.3 & 11.7 & 12.0 & 323 \\
\hline $\mathrm{Pr}$ & 1.63 & 1.43 & 0.91 & 299 & 2.40 & 2.08 & 1.77 & 331 & 2.07 & 1.89 & 1.01 & 235 \\
\hline $\mathrm{Nd}$ & 10.9 & 9.83 & 5.21 & 881 & 12.23 & 10.90 & 7.83 & 522 & 10.7 & 9.66 & 6.01 & 361 \\
\hline Sm & 3.36 & 3.17 & 1.18 & 863 & 3.94 & 3.65 & 1.99 & 538 & 3.34 & 3.14 & 1.38 & 356 \\
\hline $\mathrm{Eu}$ & 1.23 & 1.17 & 0.37 & 828 & 1.41 & 1.33 & 0.56 & 487 & 1.21 & 1.16 & 0.41 & 324 \\
\hline $\mathrm{Gd}$ & 4.40 & 4.23 & 1.25 & 781 & 5.27 & 4.88 & 2.66 & 413 & 4.24 & 4.03 & 1.55 & 253 \\
\hline $\mathrm{Tb}$ & 0.705 & 0.683 & 0.174 & 333 & 0.94 & 0.86 & 0.61 & 355 & 0.73 & 0.71 & 0.17 & 259 \\
\hline Dy & 5.08 & 4.94 & 1.2 & 772 & 6.31 & 5.88 & 3.06 & 426 & 4.91 & 4.74 & 1.44 & 288 \\
\hline $\mathrm{Ho}$ & 1.04 & 1.01 & 0.24 & 290 & 1.30 & 1.22 & 0.57 & 325 & 1.03 & 1.00 & 0.24 & 232 \\
\hline $\mathrm{Yb}$ & 3.01 & 2.93 & 0.71 & 812 & 3.71 & 3.47 & 1.77 & 474 & 2.84 & 2.74 & 0.78 & 322 \\
\hline Lu & 0.447 & 0.436 & 0.099 & 572 & 0.56 & 0.52 & 0.24 & 395 & 0.43 & 0.42 & 0.12 & 307 \\
\hline $\mathrm{Hf}$ & 2.39 & 2.20 & 1.01 & 513 & 2.99 & 2.71 & 1.71 & 382 & 2.49 & 2.27 & 1.38 & 261 \\
\hline $\mathrm{Ta}$ & 0.455 & 0.293 & 0.461 & 642 & 0.36 & 0.23 & 0.46 & 291 & 0.37 & 0.21 & 0.55 & 180 \\
\hline W & 0.048 & 0.027 & 0.090 & 36 & 0.04 & 0.03 & 0.03 & 34 & 0.04 & 0.03 & 0.05 & 24 \\
\hline $\mathrm{Pb}$ & 0.670 & 0.554 & 0.420 & 682 & 0.58 & 0.50 & 0.40 & 315 & 0.69 & 0.59 & 0.47 & 254 \\
\hline Th & 0.518 & 0.293 & 0.58 & 806 & 0.40 & 0.22 & 0.65 & 390 & 0.52 & 0.27 & 0.79 & 257 \\
\hline U & 0.158 & 0.103 & 0.16 & 782 & 0.12 & 0.08 & 0.17 & 374 & 0.15 & 0.09 & 0.22 & 250 \\
\hline
\end{tabular}

anomalies in MORB result from plagioclase fractionation. As is discussed in a subsequent section, magmas parental to MORB, and the oceanic crust as a whole, appear to have a slight positive Eu anomaly, as suggested by Niu and O'Hara (2009).

Table 4 lists a selection of mean and median values of commonly used trace element ratios in global MORB and $\mathrm{N}$ MORB. Low ratios of more incompatible elements to less incompatible elements, such as $\mathrm{Ba} / \mathrm{La}$, reflect the general incompatible element depletion of MORB and, as expected, are lower in N-MORB than the global mean MORB. Ratios such as these have high standard deviations, reflecting the heterogeneous nature of MORB trace element concentrations. Other ratios, the so-called canonical trace element ratios, remain constant or nearly constant, as pointed out in earlier studies. The ratios $\mathrm{Ba} / \mathrm{Rb}, \mathrm{Cs} / \mathrm{Rb}, \mathrm{Pb} / \mathrm{Ce}$, and $\mathrm{Nb} / \mathrm{U}$ all show mean values quite close to those initially proposed by Hofmann and White (1983), Newsom et al. (1986), and Hofmann et al. (1986). Nb/Ta and $\mathrm{Zr} / \mathrm{Hf}$ also show only limited variation; the $\mathrm{Zr} / \mathrm{Hf}$ ratio in MORB is equal to the chondritic value within uncertainty, while the $\mathrm{Nb} / \mathrm{Ta}$ value is somewhat lower. Arevalo and McDonough (2010) suggested a test of the constancy of trace element ratios using log-log correlations. If the ratio of two trace elements is indeed insensitive to magmatic processes, the elements should obey the following equation:

$$
\log C_{i}^{\mathrm{MORB}}=\log C_{j}^{\mathrm{MORB}}+\log \frac{C_{i}^{\text {mantle }}}{C_{j}^{\text {mantle }}}
$$

where $C_{i}$ and $C_{j}$ are the concentrations of the elements of interest and the superscript mantle refers to the mantle source. In other words, the slope on a log-log plot should be 1 and the intercept should give the log value of the ratio in both the source and the magma. Using this test, they found that the $\mathrm{Pb} /$ $\mathrm{Ce}$ and $\mathrm{Y} / \mathrm{Ho}$ ratios were indeed constant, but those of $\mathrm{Zr} / \mathrm{Hf}$ and $\mathrm{Nb} /$ Ta were not. Arevalo and McDonough (2010) found 


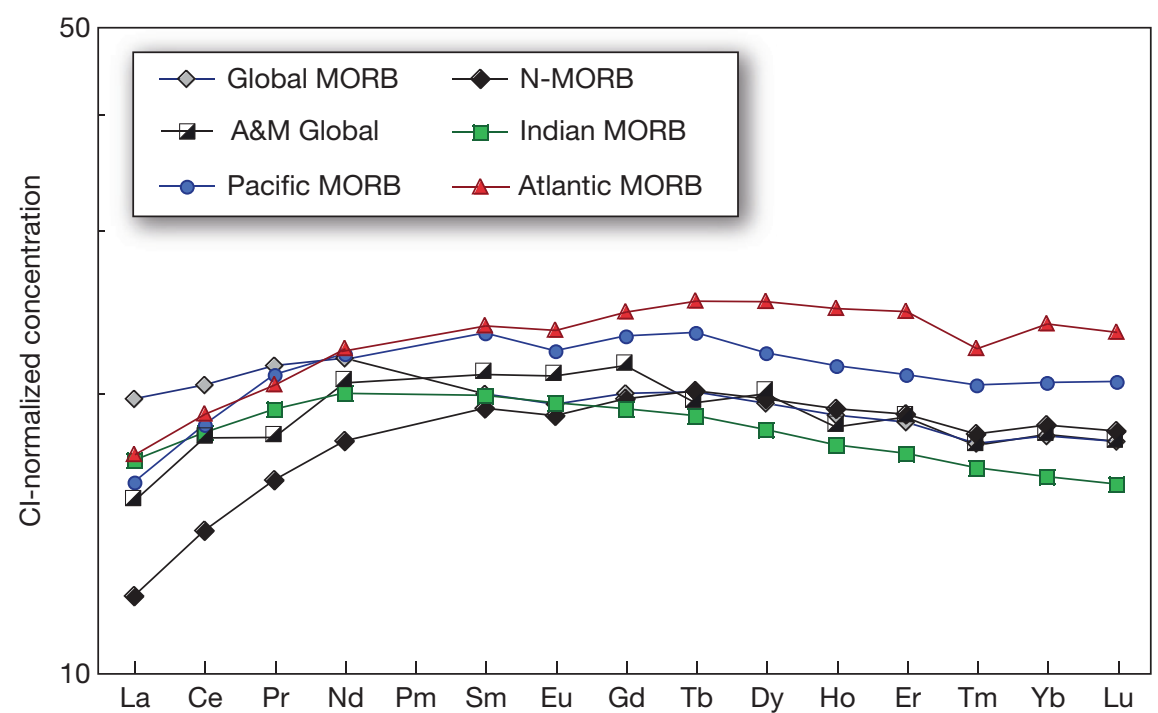

Figure $8 \mathrm{Cl}$-chondrite-normalized rare-earth patterns of the global and regional MORB average listed in Tables 2 and 3. A\&M is the log-normal average MORB of Arevalo and McDonough (2010).

Table 4 Average trace element ratios in MORB and back-arc basin basalts (BABB)

\begin{tabular}{|c|c|c|c|c|c|c|c|c|c|c|}
\hline & \multicolumn{4}{|c|}{ Global MORB } & \multicolumn{3}{|c|}{$N-M O R B$} & \multicolumn{3}{|c|}{ Global $B A B B$} \\
\hline & Mean & Median & $\sigma$ & $\mathrm{n}$ & Mean & $\sigma$ & $\mathrm{n}$ & Mean & $\sigma$ & $\mathrm{n}$ \\
\hline $\mathrm{La} / \mathrm{Sm}$ & 1.43 & 1.12 & 0.81 & 1637 & 1.01 & 0.25 & 1173 & 1.80 & 0.87 & 318 \\
\hline$(\mathrm{La} / \mathrm{Sm})_{\mathrm{N}}$ & 0.90 & 0.70 & 0.51 & 1637 & 0.63 & 0.16 & 1173 & 1.13 & 0.54 & 318 \\
\hline $\mathrm{La} / \mathrm{Yb}$ & 1.84 & 1.17 & 1.84 & 1576 & 1.04 & 0.37 & 1120 & 2.20 & 1.60 & 326 \\
\hline $\mathrm{Sm} / \mathrm{Yb}$ & 1.13 & 1.07 & 0.34 & 1599 & 1.01 & 0.18 & 1148 & 1.18 & 0.30 & 341 \\
\hline $\mathrm{Ba} / \mathrm{La}$ & 6.05 & 5.33 & 3.76 & 1522 & 4.41 & 2.77 & 1038 & 14.00 & 10.10 & 349 \\
\hline $\mathrm{Nb} / \mathrm{La}$ & 0.95 & 0.92 & 0.33 & 1389 & 0.81 & 0.24 & 959 & 0.64 & 0.36 & 285 \\
\hline $\mathrm{Zr} / \mathrm{Nb}$ & 30.73 & 26.64 & 22.03 & 1363 & 39.83 & 20.83 & 935 & 38.0 & 30.7 & 347 \\
\hline $\mathrm{Sm} / \mathrm{Nd}$ & 0.333 & 0.338 & 0.043 & 1704 & 0.353 & 0.029 & 1227 & 0.312 & 0.044 & 418 \\
\hline $\mathrm{Ba} / \mathrm{Rb}$ & 11.5 & 11.2 & 2.6 & 1162 & 11.2 & 2.6 & 713 & 11.9 & 5.9 & 474 \\
\hline $\mathrm{Rb} / \mathrm{Cs}$ & 83.4 & 81.2 & 25.6 & 582 & 77.8 & 25.2 & 365 & 52.8 & 20.4 & 184 \\
\hline $\mathrm{Pb} / \mathrm{Ce}$ & 0.045 & 0.044 & 0.011 & 1174 & 0.046 & 0.0117 & 763 & 0.11 & 0.07 & 230 \\
\hline $\mathrm{Nb} / \mathrm{Ta}$ & 15.3 & 15.4 & 1.6 & 1090 & 14.9 & 1.6 & 743 & 15.2 & 2.35 & 174 \\
\hline $\mathrm{Zr} / \mathrm{Hf}$ & 37.5 & 37.2 & 4.1 & 1092 & 36.6 & 3.7 & 808 & 38.6 & 5.21 & 233 \\
\hline $\mathrm{Rb} / \mathrm{Sr}$ & 0.024 & 0.016 & 0.021 & 1247 & 0.013 & 0.009 & 783 & 0.038 & 0.06 & 547 \\
\hline Th/U & 3.06 & 3.00 & 0.90 & 1382 & 2.82 & 0.89 & 861 & 2.85 & 0.66 & 197 \\
\hline $\mathrm{U} / \mathrm{Pb}$ & 0.208 & 0.181 & 0.122 & 1162 & 0.155 & 0.088 & 738 & 0.164 & 0.07 & 177 \\
\hline $\mathrm{Nb} / \mathrm{U}$ & 45.1 & 45.2 & 9.9 & 1201 & 44.2 & 11.3 & 796 & 20.76 & 14.47 & 185 \\
\hline $\mathrm{K} / \mathrm{U}$ & 16775 & 16469 & 3753 & 131 & 17328 & 3652 & 103 & 17351 & 4189 & 136 \\
\hline $\mathrm{K} / \mathrm{Rb}$ & 907.1 & 848.7 & 468.6 & 108 & 956.3 & 455.3 & 77 & 529 & 193 & 433 \\
\hline $\mathrm{K} / \mathrm{La}$ & 280.5 & 275.2 & 71.7 & 139 & 265.4 & 58.2 & 115 & 595 & 310 & 289 \\
\hline W/U & 0.60 & 0.47 & 0.34 & 94 & 0.61 & 0.37 & 77 & - & - & - \\
\hline $\mathrm{Y} / \mathrm{Ho}_{0}$ & 28.1 & 27.9 & 2.49 & 788 & 28.1 & 2.13 & 624 & 28.4 & 3.9 & 222 \\
\hline $\mathrm{Eu}^{*}$ & 0.98 & 0.98 & 0.09 & 1447 & 0.97 & 0.09 & 1028 & 0.99 & 0.08 & 326 \\
\hline $\mathrm{Sr}^{*}$ & 0.82 & 0.79 & 0.025 & 1554 & 0.77 & 0.2 & 1114 & 1.40 & 0.74 & 388 \\
\hline
\end{tabular}

$E u^{*}$ is the europium anomaly, calculated as $E u_{N} /\left(\mathrm{Sm}_{N} \times \mathrm{Gd}_{N}\right)^{1 / 2}$ and $\mathrm{Sr}^{*}$ is the strontium anomaly calculated as $\mathrm{Sr}_{N} /\left(\mathrm{Nd}_{N} \times \mathrm{Sm}_{N}\right)^{1 / 2}$, where the subscript $\mathrm{N}$ indicates the bulk silicate Earth-normalized concentration.

that the slope of the $\mathrm{Nb}-\mathrm{U}$ correlation was $1.05 \pm 0.02$, implying a small but real variability in the $\mathrm{Nb} / \mathrm{U}$ ratio. In the dataset compiled here, the slope of $\log (\mathrm{U})$ versus $\log (\mathrm{Nb})$ is $1.017 \pm 0.007$ with an intercept corresponding to $\mathrm{Nb} / \mathrm{U}$ of 45.8; the slope of $\log (\mathrm{Rb})$ versus $\log (\mathrm{Cs})$ is $0.915 \pm 0.01$ with an intercept corresponding to $\mathrm{Cs} / \mathrm{Rb}$ of 0.0135 ; and the slope of $\log (\mathrm{Ba})$ versus $\log (\mathrm{Rb})$ is $0.998 \pm 0.006$ with an intercept of
11.3. Thus the $\mathrm{Nb} / \mathrm{U}$ and $\mathrm{Cs} / \mathrm{Rb}$ ratios seem to be slightly sensitive to magmatic processes, while the $\mathrm{Ba} / \mathrm{Rb}$ ratio appears to be constant.

Another test of the constancy of ratios is their correlations with other ratios. Table 5 shows a correlation matrix for trace element ratios in global MORB. Particularly strong correlations are shown in bold (all of these are statistically significant at the 
Table 5 Correlation matrix for trace element ratios in MORB

\begin{tabular}{|c|c|c|c|c|c|c|c|c|c|c|c|c|c|c|c|c|c|c|c|c|c|c|c|}
\hline & $\mathrm{La} / \mathrm{Sm}$ & $L a Y Y b$ & $S m / Y b$ & $B a / L a$ & $N b / L a$ & $Z r / N b$ & $S m / N d$ & $B a / R b$ & $R b / C s$ & $\mathrm{~Pb} / \mathrm{Ce}$ & $\mathrm{Nb} / \mathrm{Ta}$ & $\mathrm{Zr} / \mathrm{Hf}$ & $R b / S r$ & $T h / U$ & $U / P b$ & $N b / U$ & $K / U$ & $K / R b$ & $K / L a$ & W/U & $\mathrm{Y} / \mathrm{Ho}$ & $E u^{*}$ & $S r^{*}$ \\
\hline La/Sm & 1 & & & & & & & & & & & & & & & & & & & & & & \\
\hline $\mathrm{La} / \mathrm{Yb}$ & 0.92 & 1 & & & & & & & & & & & & & & & & & & & & & \\
\hline $\mathrm{Sm} / \mathrm{Yb}$ & 0.77 & 0.90 & 1 & & & & & & & & & & & & & & & & & & & & \\
\hline $\mathrm{Ba} / \mathrm{La}$ & 0.68 & 0.56 & 0.43 & 1 & & & & & & & & & & & & & & & & & & & \\
\hline $\mathrm{Nb} / \mathrm{La}$ & 0.70 & 0.56 & 0.42 & 0.70 & 1 & & & & & & & & & & & & & & & & & & \\
\hline $\mathrm{Zr} / \mathrm{Nb}$ & -0.68 & -0.53 & -0.42 & -0.71 & -0.83 & 1 & & & & & & & & & & & & & & & & & \\
\hline $\mathrm{Sm} / \mathrm{Nd}$ & -0.88 & -0.78 & -0.73 & -0.53 & -0.61 & 0.62 & 1 & & & & & & & & & & & & & & & & \\
\hline $\mathrm{Ba} / \mathrm{Rb}$ & 0.15 & 0.15 & 0.13 & 0.31 & -0.04 & -0.03 & -0.10 & 1 & & & & & & & & & & & & & & & \\
\hline $\mathrm{Rb} / \mathrm{Cs}$ & 0.29 & 0.32 & 0.37 & 0.16 & 0.13 & -0.27 & -0.33 & -0.02 & 1 & & & & & & & & & & & & & & \\
\hline $\mathrm{Pb} / \mathrm{Ce}$ & -0.24 & -0.22 & -0.21 & -0.08 & -0.34 & 0.28 & 0.25 & 0.10 & -0.04 & 1 & & & & & & & & & & & & & \\
\hline $\mathrm{Nb} / \mathrm{Ta}$ & 0.44 & 0.37 & 0.33 & 0.49 & 0.56 & -0.51 & -0.42 & -0.05 & 0.27 & -0.07 & 1 & & & & & & & & & & & & \\
\hline $\mathrm{Zr} / \mathrm{Hf}$ & 0.46 & 0.42 & 0.48 & 0.17 & 0.28 & -0.29 & -0.61 & -0.06 & 0.13 & -0.14 & 0.29 & 1 & & & & & & & & & & & \\
\hline $\mathrm{Rb} / \mathrm{Sr}$ & 0.77 & 0.61 & 0.52 & 0.65 & 0.64 & -0.67 & -0.71 & -0.06 & 0.24 & -0.25 & 0.44 & 0.41 & 1 & & & & & & & & & & \\
\hline Th/U & 0.41 & 0.33 & 0.33 & 0.44 & 0.23 & -0.38 & -0.40 & 0.28 & 0.28 & 0.04 & 0.16 & 0.28 & 0.39 & 1 & & & & & & & & & \\
\hline $\mathrm{U} / \mathrm{Pb}$ & 0.67 & 0.57 & 0.44 & 0.57 & 0.78 & -0.60 & -0.58 & -0.02 & 0.05 & -0.59 & 0.34 & 0.33 & 0.61 & 0.09 & 1 & & & & & & & & \\
\hline $\mathrm{Nb} / \mathrm{U}$ & 0.19 & 0.13 & 0.17 & 0.20 & 0.25 & -0.36 & -0.20 & 0.15 & 0.13 & -0.17 & 0.20 & 0.15 & 0.17 & 0.58 & -0.08 & 1 & & & & & & & \\
\hline K/U & -0.34 & -0.31 & -0.31 & -0.28 & -0.53 & 0.39 & 0.33 & 0.20 & 0.16 & 0.66 & -0.25 & -0.28 & -0.68 & 0.31 & -0.65 & -0.10 & 1 & & & & & & \\
\hline $\mathrm{K} / \mathrm{Rb}$ & -0.34 & -0.34 & 0.06 & -0.60 & -0.43 & 0.27 & 0.28 & 0.28 & -0.06 & 0.31 & & 0.36 & -0.53 & -0.45 & -0.44 & -0.15 & 0.37 & 1 & & & & & \\
\hline K/La & 0.43 & 0.44 & 0.52 & 0.61 & 0.62 & -0.59 & -0.49 & 0.16 & -0.25 & 0.07 & 0.48 & 0.14 & 0.54 & 0.18 & 0.47 & -0.19 & 0.14 & -0.16 & 1 & & & & \\
\hline W/U & -0.18 & -0.13 & -0.37 & 0.04 & -0.24 & 0.46 & 0.47 & 0.41 & -0.24 & 0.37 & -0.11 & -0.45 & 0.47 & 0.14 & -0.13 & -0.16 & 0.29 & & -0.03 & 1 & & & \\
\hline $\mathrm{Y} / \mathrm{Ho}$ & 0.06 & 0.05 & 0.09 & 0.05 & 0.01 & -0.10 & -0.09 & 0.08 & -0.11 & 0.02 & -0.04 & 0.26 & -0.01 & 0.12 & -0.06 & 0.27 & -0.06 & 0.08 & -0.18 & 0.10 & 1 & & \\
\hline $\mathrm{Eu}^{\star}$ & 0.12 & 0.15 & 0.16 & 0.14 & 0.04 & -0.02 & -0.10 & 0.07 & 0.08 & 0.08 & 0.15 & -0.04 & -0.10 & -0.04 & -0.03 & 0.00 & 0.20 & -0.03 & 0.23 & 0.14 & 0.01 & 1 & \\
\hline $\mathrm{Sr}^{*}$ & 0.35 & 0.36 & 0.30 & 0.41 & 0.22 & -0.18 & -0.26 & 0.26 & 0.05 & 0.07 & 0.18 & 0.17 & -0.01 & 0.10 & 0.17 & 0.08 & 0.23 & 0.14 & 0.45 & 0.14 & 0.22 & 0.48 & 1 \\
\hline
\end{tabular}

$\mathrm{Eu}^{\star}$ and $\mathrm{Sr}^{\star}$ are the europium and strontium anomalies, respectively, as defined in Table 4. 
$5 \%$ level; however, some correlations not shown in bold are also statistically significant). $\mathrm{Ba} / \mathrm{Rb}, \mathrm{Cs} / \mathrm{Rb}, \mathrm{Pb} / \mathrm{Ce}$, and $\mathrm{Y} / \mathrm{Ho}$ do not show strong correlations with other ratios; $\mathrm{Nb} / \mathrm{U}$ correlates strongly only with $\mathrm{Th} / \mathrm{U}$, but this reflects only a general correlation between $\mathrm{Nb}$ and $\mathrm{U}$ and could well result in part from analytical error in U concentrations (which are typically less than $100 \mathrm{ppb}$ ). On the other hand, $\mathrm{Nb} / \mathrm{Ta}$ and $\mathrm{Zr} / \mathrm{Hf}$ show multiple strong correlations with other trace element ratios, implying that they are indeed magmatically fractionated. Thus, the data generally support the notion of the constancy or near constancy of $\mathrm{Ba} / \mathrm{Rb}, \mathrm{Cs} / \mathrm{Rb}, \mathrm{Pb} / \mathrm{Ce}$, and $\mathrm{Nb} / \mathrm{U}$ ratios proposed by Hofmann and White (1983), Newsom et al. (1986), and Hofmann et al. (1986), but do not support the notion that either $\mathrm{Nb} / \mathrm{Ta}$ or $\mathrm{Zr} / \mathrm{Hf}$ is constant.

\subsection{Isotope ratios}

Mean radiogenic and stable isotope ratios of MORB are listed in Table 6. Variations in radiogenic isotope ratios result from variations in parent/daughter ratios over great lengths of time. For example, to create a variation of one $\varepsilon_{\mathrm{Nd}}$ unit in ${ }^{143} \mathrm{Nd} /{ }^{144} \mathrm{Nd}$ would require a variation in ${ }^{147} \mathrm{Sm} /{ }^{144} \mathrm{Nd}$ of 0.02 (about $10 \%$ ) that existed for $1.4 \mathrm{Ga}$. Consequently, radiogenic isotope ratios reflect long-standing chemical variations in the mantle source (except where magmas might have recently assimilated crustal material, such as sediment, or have reacted with seawater). Correlations that exist between radiogenic isotope ratios, such as those apparent in Figures 9-12, reflect ancient coupled fractionations in parent/daughter ratios. Sr, $\mathrm{Nd}$, and $\mathrm{Hf}$ isotope ratios are generally strongly correlated with one another, as are the three $\mathrm{Pb}$ isotope ratios. On the other hand, correlations between $\mathrm{Pb}$ isotope ratios and the $\mathrm{Sr}, \mathrm{Nd}$, and Hf isotope ratios are weak in the dataset overall. However, strong, statistically significant correlations between $\mathrm{Pb}$ isotope ratios and other isotope ratios do exist within subsets of the data. For example, ${ }^{87} \mathrm{Sr} /{ }^{86} \mathrm{Sr}$ and $\varepsilon_{\mathrm{Nd}}$ correlate strongly with ${ }^{206} \mathrm{~Pb} /{ }^{204} \mathrm{~Pb}$ within Pacific MORB and within North Atlantic $\mathrm{N}$-MORB. Some, but not all, samples that deviate from these correlations come from ridge segments close to oceanic islands and reflect the influence of mantle plumes on those segments (e.g., Schilling, 1985). There are also systematic differences in radiogenic isotope ratios between ocean basins, which are discussed below.

The mean $\varepsilon_{\mathrm{Nd}}$ of the global MORB dataset is 8.53 , implying that the MORB source reservoir is depleted in light rare earths compared to chondrites, consistent with $(\mathrm{La} / \mathrm{Sm})_{\mathrm{N}}$ less than 1 . The isotope data indicate that this depletion has existed for a

Table 6 Isotope ratios in MORB and BABB

\begin{tabular}{|c|c|c|c|c|c|c|c|c|c|c|c|c|c|c|}
\hline & ${ }^{87} \mathrm{Sr}{ }^{86} \mathrm{Sr}$ & $\varepsilon_{N d}$ & ${ }^{206} \mathrm{~Pb} /{ }^{204} \mathrm{~Pb}$ & ${ }^{207} \mathrm{~Pb} /{ }^{204} \mathrm{~Pb}$ & ${ }^{208} \mathrm{~Pb}{ }^{204} \mathrm{~Pb}$ & $\varepsilon_{H f}$ & $\gamma_{O s}$ & $\delta^{7} L i$ & $\delta^{18} 0$ & $\delta^{13} C$ & $\delta D$ & $\delta^{15} N$ & $\delta^{34} S$ & $\delta^{11} B$ \\
\hline \multicolumn{15}{|l|}{ Global } \\
\hline Mean & 0.70289 & 8.53 & 18.404 & 15.505 & 38.082 & 14.19 & 18.1 & 3.81 & 5.69 & -5.99 & -67.14 & -2.00 & 0.06 & -4.25 \\
\hline Median & 0.70282 & 8.95 & 18.349 & 15.497 & 38.001 & 14.25 & 12.0 & 3.80 & 5.64 & -6.30 & -66.90 & -2.20 & 0.20 & -4.35 \\
\hline$\sigma$ & 0.00048 & 2.29 & 0.449 & 0.054 & 0.450 & 4.04 & 26.7 & 1.33 & 0.33 & 1.69 & 11.23 & 2.51 & 1.66 & 2.13 \\
\hline$n$ & 1557 & 1411 & 1372 & 1345 & 1345 & 526 & 72 & 47 & 216 & 68 & 95 & 72 & 11 & 20 \\
\hline Mean & 0.70273 & 9.25 & 18.283 & 15.490 & 37.916 & 15.04 & & & & & & & & \\
\hline Median & 0.70270 & 9.48 & 18.284 & 15.487 & 37.867 & 14.57 & & & & & & & & \\
\hline$\sigma$ & 0.00030 & 1.57 & 0.338 & 0.044 & 0.327 & 3.36 & & & & & & & & \\
\hline$n$ & 1094 & 985 & 877 & 857 & 857 & 328 & & & & & & & & \\
\hline \multicolumn{15}{|l|}{ Atlantic } \\
\hline Mean & 0.70304 & 8.31 & 18.493 & 15.511 & 38.195 & 14.81 & 19.9 & 3.87 & 5.74 & -6.50 & -69.21 & -0.94 & -0.58 & -4.91 \\
\hline Median & 0.70296 & 8.90 & 18.384 & 15.508 & 38.163 & 15.86 & 14.9 & 3.90 & 5.67 & -7.00 & -70.00 & -1.50 & -0.10 & -5.10 \\
\hline$n$ & 610 & 564 & 581 & 560 & 560 & 292 & 43 & 23 & 78 & 23 & 57 & 11 & 6 & 11 \\
\hline \multicolumn{15}{|l|}{ Pacific } \\
\hline Mean & 0.70261 & 9.37 & 18.502 & 15.508 & 38.025 & 13.23 & 11.8 & 3.65 & 5.68 & -6.65 & -64.03 & -3.03 & 0.84 & -3.91 \\
\hline Median & 0.70254 & 9.54 & 18.460 & 15.498 & 37.953 & 13.69 & 10.1 & 3.70 & 5.62 & -7.40 & -64.00 & -3.25 & 1.00 & -4.20 \\
\hline$\sigma$ & 0.00023 & 1.40 & 0.295 & 0.044 & 0.372 & 2.04 & 10.0 & 1.00 & 0.28 & 2.43 & 12.06 & 2.64 & 0.50 & 1.65 \\
\hline$n$ & 566 & 493 & 449 & 444 & 444 & 141 & 10 & 25 & 115 & 9 & 38 & 20 & 5 & 7 \\
\hline \multicolumn{15}{|l|}{ Indian } \\
\hline Mean & 0.70307 & 7.72 & 18.125 & 15.490 & 37.972 & 13.70 & 17.3 & 3.49 & 5.58 & -5.50 & & -1.79 & & -1.80 \\
\hline Median & 0.70296 & 7.92 & 18.074 & 15.483 & 37.892 & 13.97 & 8.3 & 3.90 & 5.55 & -5.90 & & -2.00 & & -1.80 \\
\hline$\sigma$ & 0.00040 & 2.01 & 0.461 & 0.051 & 0.458 & 3.51 & 34.7 & 0.85 & 0.18 & 1.52 & & 2.20 & & 0.85 \\
\hline$n$ & 381 & 354 & 342 & 341 & 341 & 93 & 19 & 7 & 23 & 36 & 0 & 41 & 0 & 2 \\
\hline \multicolumn{15}{|l|}{ BABB } \\
\hline Mean & 0.70323 & 7.87 & 18.480 & 15.531 & 38.221 & 16.41 & & & 5.81 & -6.80 & -44.15 & 0.07 & 1.09 & -2.90 \\
\hline Median & 0.70320 & 8.10 & 18.487 & 15.536 & 38.199 & 15.29 & & & 5.80 & -7.19 & -40.90 & -0.10 & 0.80 & -1.80 \\
\hline
\end{tabular}

$\varepsilon_{\mathrm{Nd}}$ is calculated as $\left[\left({ }^{143} \mathrm{Nd} /{ }^{144} \mathrm{Nd}\right)_{\text {sample }} /\left({ }^{143} \mathrm{Nd} / /^{144} \mathrm{Nd}\right)_{\text {chondrites }}-1\right] \times 10000$ where $\left({ }^{143} \mathrm{Nd} /{ }^{144} \mathrm{Nd}\right)_{\text {chondrites }}=0.512638 ; \varepsilon_{\mathrm{Hf}}$ is calculated as $\left[\left({ }^{177} \mathrm{Hf} /{ }^{176} \mathrm{Hf}\right)_{\text {sample }} /\right.$ $\left.\left({ }^{177} \mathrm{Hf} /{ }^{176} \mathrm{Hf}\right)_{\text {chondrites }}-1\right] \times 10000$ where $\left({ }^{177} \mathrm{Hf} /{ }^{176} \mathrm{Hf}\right)_{\text {chondrites }}=0.282786$; $\gamma_{0 \text { s }}$ is calculated as $\left[\left({ }^{187} \mathrm{OS} /{ }^{188} \mathrm{Os}\right)_{\text {sample }}\left({ }^{187} \mathrm{OS} /{ }^{188} \mathrm{OS}\right)_{\text {primitive upper mantle }}-1\right] \times 100$ where $\left({ }^{187} \mathrm{Os} /{ }^{188} \mathrm{OS}\right)_{\text {primitive upper mantle }}=0.1290$. 


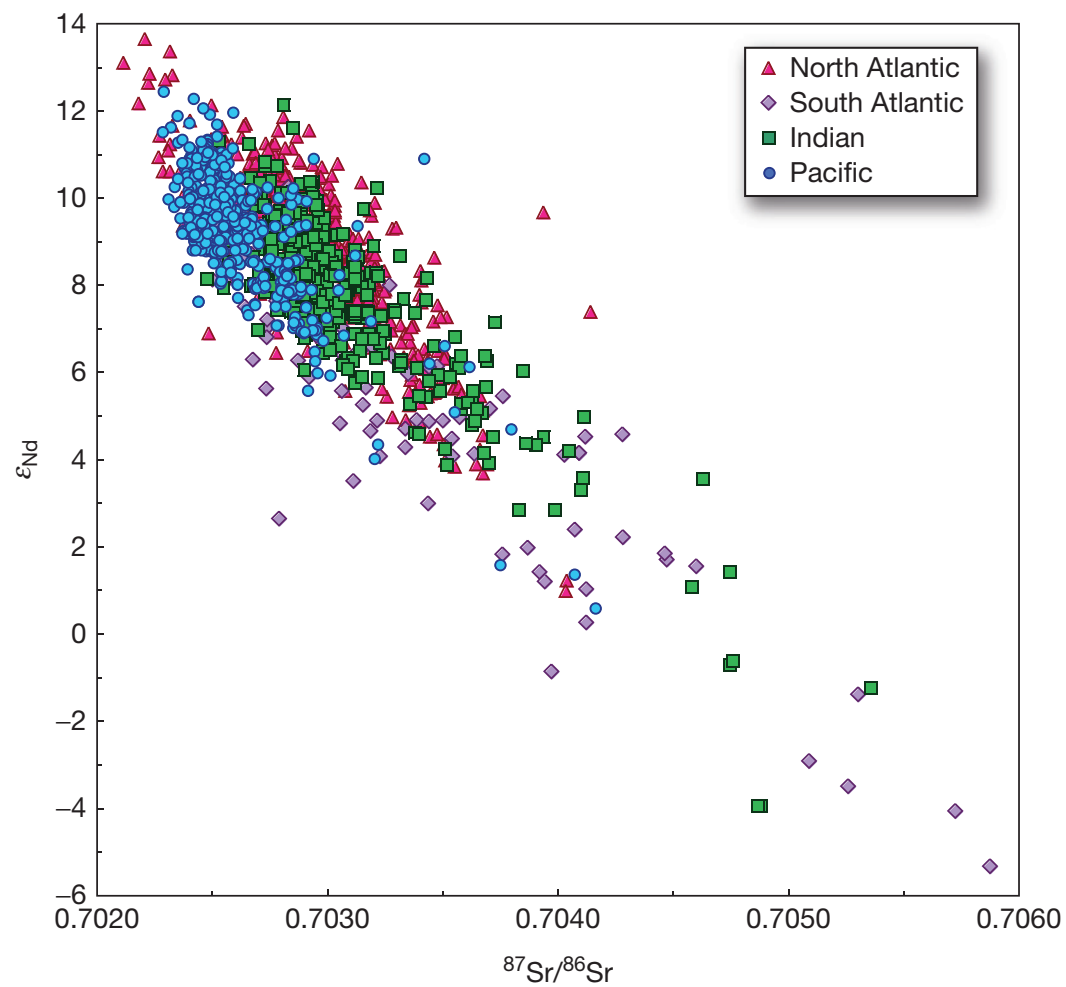

Figure $9 \mathrm{Sr}$ and $\mathrm{Nd}$ isotope ratios in mid-ocean ridge basalts. North Atlantic is north of $23^{\circ} \mathrm{S}$ (defined on the basis of coherent isotope signatures rather than latitude) and the Bouvet triple junction and the Australian-Antarctic discordance at $127^{\circ} \mathrm{E}$ are taken as the west and east boundaries, respectively, of the Indian Ocean. The actual boundary between the 'South Atlantic mantle domain' and 'Indian mantle domain' may be the Andrew Bain Fracture Zone at $30^{\circ} \mathrm{E}$ (Meyzen et al., 2007). Data from PetDB.

significant fraction of Earth's history. However, ${ }^{142} \mathrm{Nd} /{ }^{144} \mathrm{Nd}$ measurements show that the Earth as a whole, or at least the observable part of it, is also light-rare-earth depleted (Boyet and Carlson, 2005). These measurements suggest that the ${ }^{147} \mathrm{Sm} /{ }^{144} \mathrm{Nd}$ ratio of the bulk silicate Earth, or at least the observable part of it, is about 0.208 , compared with a chondritic value of 0.196 (Boyet and Carlson, 2005; Caro and Bourdon, 2010). This corresponds to a present day $\varepsilon_{\mathrm{Nd}}$ of about +7 . To produce the mean $\mathrm{MORB} \varepsilon_{\mathrm{Nd}}$ requires a ${ }^{147} \mathrm{Sm} /{ }^{144} \mathrm{Nd}$ ratio of 0.211 over the age of the solar system. This implies the MORB source is only slightly depleted in light rare earths compared to the observable Earth.

Lead isotopes provide particular insights into the temporal evolution of mantle sources as the two isotopes of $\mathrm{U}$, namely, ${ }^{238} \mathrm{U}$ and ${ }^{235} \mathrm{U}$, decay to ${ }^{206} \mathrm{~Pb}$ and ${ }^{207} \mathrm{~Pb}$ at very different rates. Thus, the relationship between ${ }^{206} \mathrm{~Pb} /{ }^{204} \mathrm{~Pb}$ and ${ }^{207} \mathrm{~Pb} /{ }^{204} \mathrm{~Pb}$ reflects the timing of $\mathrm{U}-\mathrm{Pb}$ fractionations. Indeed, slopes on a ${ }^{207} \mathrm{~Pb} /{ }^{204} \mathrm{~Pb}-{ }^{206} \mathrm{~Pb} /{ }^{204} \mathrm{~Pb}$ plot are a function of time

$$
\frac{{ }^{207} \mathrm{~Pb} /{ }^{204} \mathrm{~Pb}}{{ }^{206} \mathrm{~Pb} /{ }^{204} \mathrm{~Pb}}=\frac{1}{137.88} \frac{\left(\mathrm{e}^{\lambda_{235} t}-1\right)}{\left(\mathrm{e}^{\lambda_{238} t}-1\right)}
$$

Precise calculation of age using this equation requires that the system of interest must have remained closed to $\mathrm{Pb}$ and $\mathrm{U}$ over time $t$, a condition that is unlikely to be met for the mantle sources of MORB. Nevertheless, the value of $t$ calculated from the slope of the data in Figure 10(b) provides a qualitative indication of the age of mantle heterogeneity. If the global dataset is used, the slope of the data corresponds to an age of
$1.43 \pm 0.05 \mathrm{Ga}$, and very similar ages are calculated from the global N-MORB, Atlantic, and Indian datasets. The slope of the Pacific data corresponds to a somewhat older age of $1.91 \pm 0.07 \mathrm{Ga}$. These ages are similar to that calculated from the oceanic island basalt dataset (White, 2010). These values almost certainly do not represent the ages of discrete events, but they do demonstrate that chemical heterogeneity in the mantle is old; it is much older than the age of oceanic crust, but much younger than the age of the Earth.

${ }^{208} \mathrm{~Pb} /{ }^{204} \mathrm{~Pb}-{ }^{206} \mathrm{~Pb} /{ }^{204} \mathrm{~Pb}$ relationships reflect fractionation between the two parent isotopes: ${ }^{232} \mathrm{Th}$ and ${ }^{238} \mathrm{U}$. For a system closed to $\mathrm{U}$, Th, and $\mathrm{Pb}$, the slope on $\mathrm{a}^{208} \mathrm{~Pb} /{ }^{204} \mathrm{~Pb}-{ }^{206} \mathrm{~Pb} /{ }^{204} \mathrm{~Pb}$ plot is a function of time and the ${ }^{232} \mathrm{Th} /{ }^{238} \mathrm{U}$ ratio $(\kappa)$ :

$$
\frac{{ }^{208} \mathrm{~Pb} /{ }^{204} \mathrm{~Pb}}{{ }^{206} \mathrm{~Pb} /{ }^{204} \mathrm{~Pb}}=\frac{\kappa\left(\mathrm{e}^{\lambda_{232} t}-1\right)}{\left(\mathrm{e}^{\lambda_{238} t}-1\right)}
$$

If the value of $t$ calculated from the ${ }^{207} \mathrm{~Pb} /{ }^{204} \mathrm{~Pb}-{ }^{206} \mathrm{~Pb} /{ }^{204} \mathrm{~Pb}$ slope is used, the ${ }^{208} \mathrm{~Pb} /{ }^{204} \mathrm{~Pb}-{ }^{206} \mathrm{~Pb} /{ }^{204} \mathrm{~Pb}$ slope of the global MORB dataset (Figure $10(\mathrm{a})$ ) corresponds to a ${ }^{232} \mathrm{Th} /{ }^{238} \mathrm{U}$ ratio of $2.96 \pm 0.04$. This is just slightly lower than the average ${ }^{232} \mathrm{Th} /{ }^{238} \mathrm{U}$ of global MORB, which is 3.16 (equivalent to $\mathrm{Th} / \mathrm{U}=3.06$ ). These isotope ratios can also be used to calculate the ${ }^{232} \mathrm{Th} /{ }^{238} \mathrm{U}$ ratio of the MORB source reservoir time-integrated over the age of the Earth, which is 3.72. This implies, not surprisingly, that the $\mathrm{Th} / \mathrm{U}$ ratio of the MORB source reservoir decreased at some point in the past (e.g., Galer and O'Nions, 1985). 

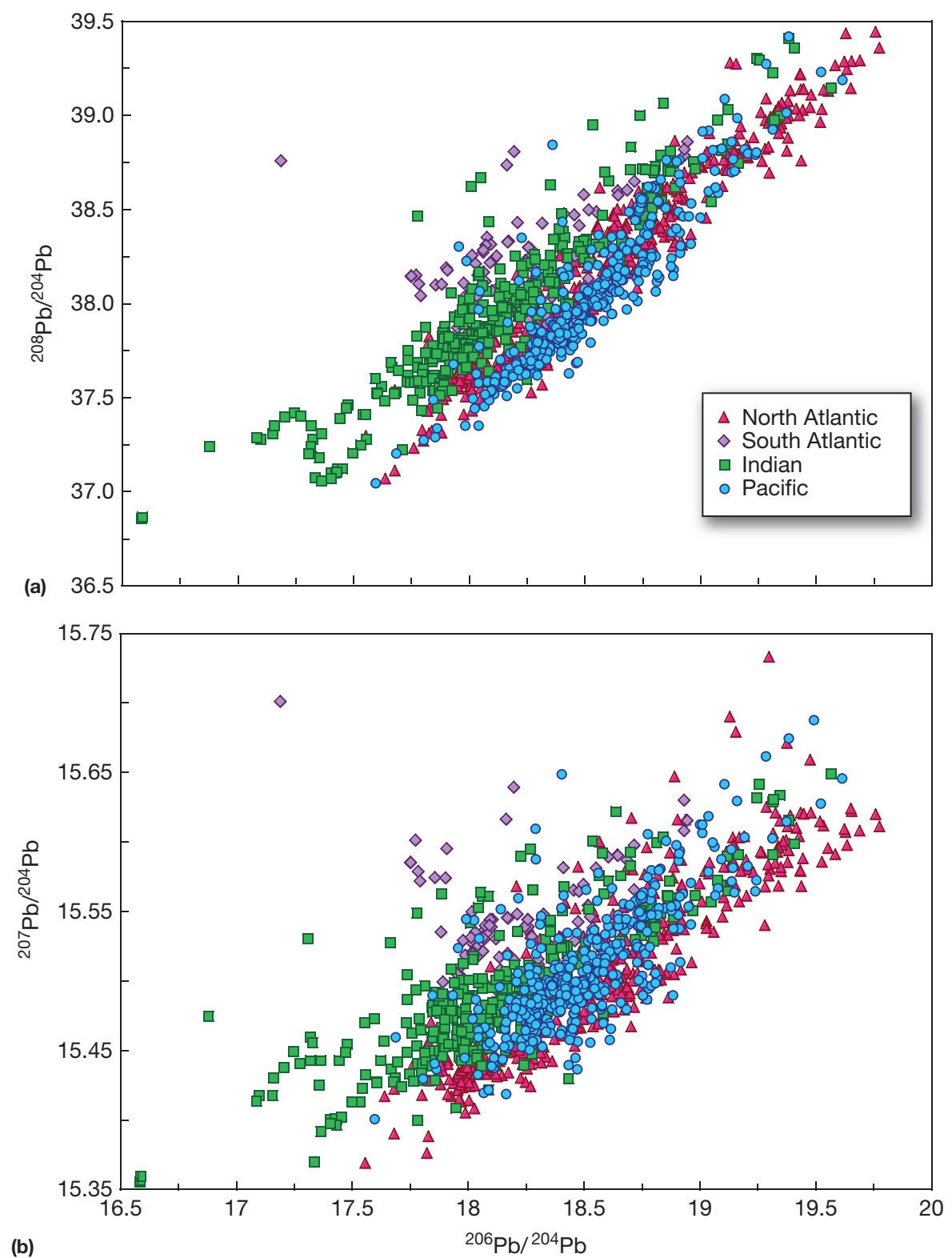

Figure $10 \mathrm{~Pb}$ isotope ratios in mid-ocean ridge basalts. (a) ${ }^{208} \mathrm{~Pb} /{ }^{204} \mathrm{~Pb}$ versus ${ }^{206} \mathrm{~Pb} /{ }^{204} \mathrm{~Pb}$; (b) ${ }^{207} \mathrm{~Pb} /{ }^{204} \mathrm{~Pb}$ versus ${ }^{206} \mathrm{~Pb} /{ }^{204} \mathrm{~Pb}$. Data from PetDB. See Figure 9 for location boundaries.

There are far fewer ${ }^{187} \mathrm{Os} /{ }^{188}$ Os data than the other radiogenic isotope ratios, undoubtedly due to the analytical difficulties that arise from the very low concentration of Os in MORB, typically no more than a few parts per trillion. Part of the reason for the low Os concentration is that, unlike the other radiogenic elements, it is strongly compatible, meaning it concentrates in residual solids during melting. Consequently, the Os concentration in peridotites is higher, typically by three orders of magnitude, than in basalts. The other reason for its extremely low concentration is that nearly all the Earth's Os is concentrated in the core. The parent element in this system, Re, is slightly to moderately incompatible; consequently, ${ }^{187} \mathrm{Re} /{ }^{188}$ Os varies over several orders of magnitude in common terrestrial rocks, resulting in a very large range in
${ }^{187} \mathrm{Os} /{ }^{188} \mathrm{Os}$ and, in particular, a very large difference between mantle and crustal rocks. Mean $\gamma_{\text {Os }}$ in MORB is +18.1 (Table 6), indicating a time-integrated Re/Os greater than that of primitive upper mantle and ordinary chondrites ( $\gamma_{\text {Os }} \equiv 0$; Meisel et al., 1996; Walker et al., 1989); in other words, the MORB have an 'enriched' Os isotopic signature, in contrast to the 'depleted' signature of $\mathrm{Sr}, \mathrm{Nd}$, and $\mathrm{Hf}$ isotopes in MORB. Os isotopic compositions in MORB are also extremely variable $(\sigma=26.7)$. The mean value listed in Table 6 may not, however, be truly representative of MORB because over half the data come from the studies of Escrig et al. (2004) and Escrig et al. (2005) that focused on regions of the South Atlantic and Indian Ocean with anomalously radiogenic $\mathrm{Sr}$ and unradiogenic $\mathrm{Nd}$ compared to the rest of the mid-ocean ridge 


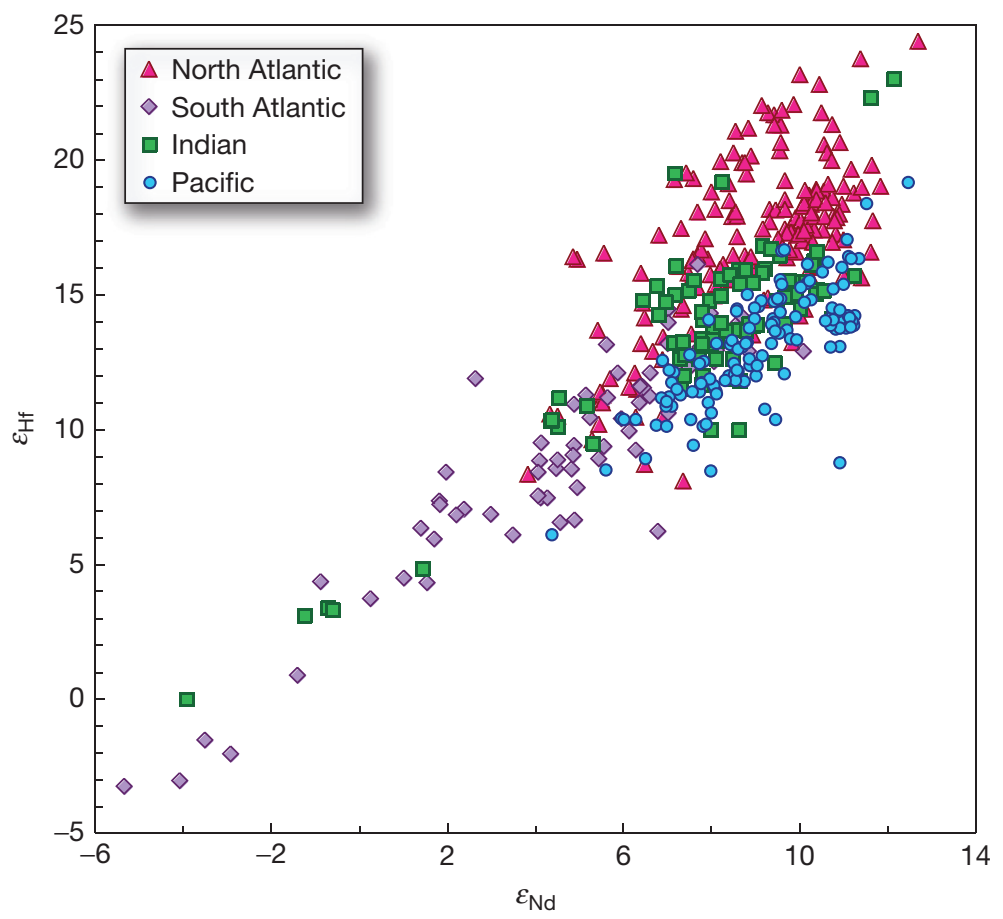

Figure $11 \mathrm{Hf}$ and Nd isotope ratios in mid-ocean ridge basalts. Data from PetDB. See Figure 9 for location boundaries.

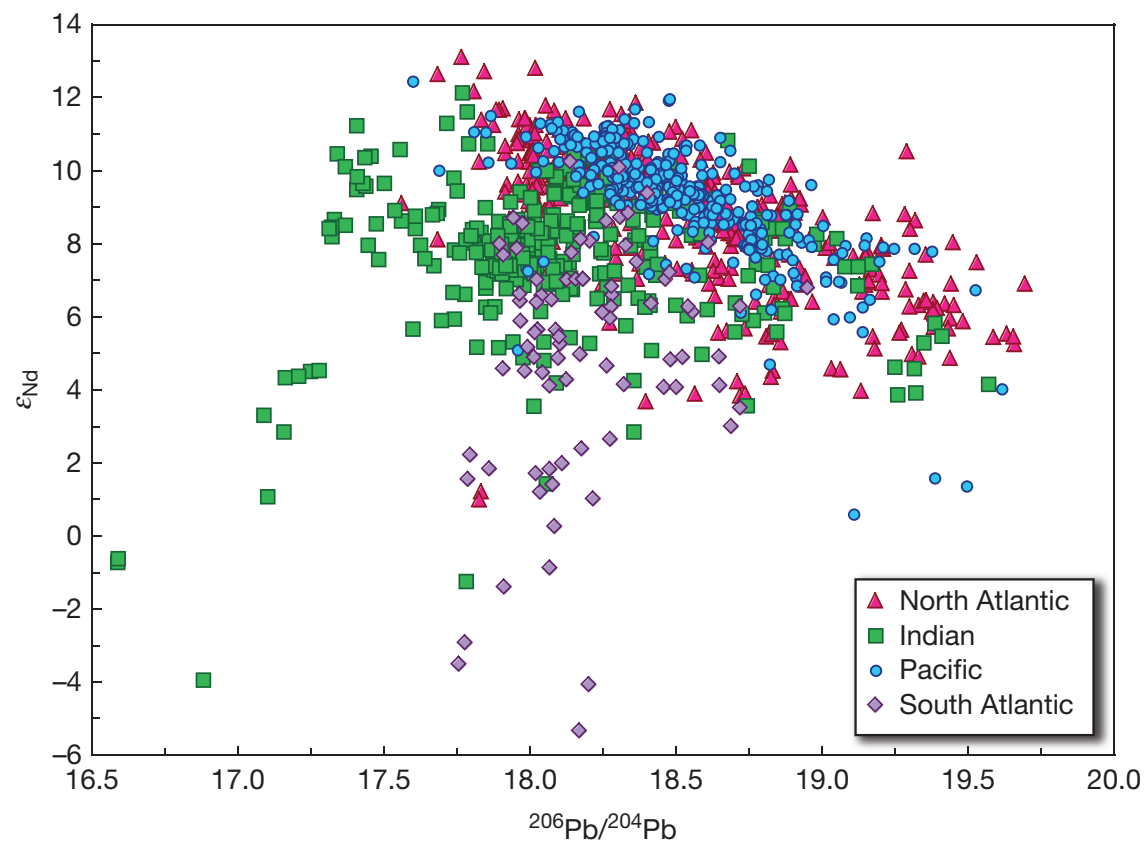

Figure $12 \mathrm{Nd}$ and $\mathrm{Pb}$ isotope ratios in mid-ocean ridge basalts. Data from PetDB. See Figure 9 for location boundaries.

system. The global median value of $\gamma_{\mathrm{Os}} \approx+12$, which is similar to the Pacific mean, may be a better indicator of MORB Os isotopic composition.

The reason for this 'enriched' signature has been the subject of debate. Of particular significance in this respect is the difference between Os isotope ratios of MORB and those of abyssal peridotites (Figure 13). Seemingly fresh abyssal peridotites have 'depleted' Os isotopic signatures with a mean $\gamma_{\mathrm{Os}}$ of -2 and are isotopically uniform $(\sigma=2.2 ; n=37)$ compared to MORB. Since abyssal peridotites presumably represent the residues of mantle that melted to produce MORB, this difference presents something of a conundrum and contrasts with $\mathrm{Nd}$ isotopes, which are largely similar in MORB and abyssal peridotites (e.g., Cipriani et al., 2004; Snow et al., 


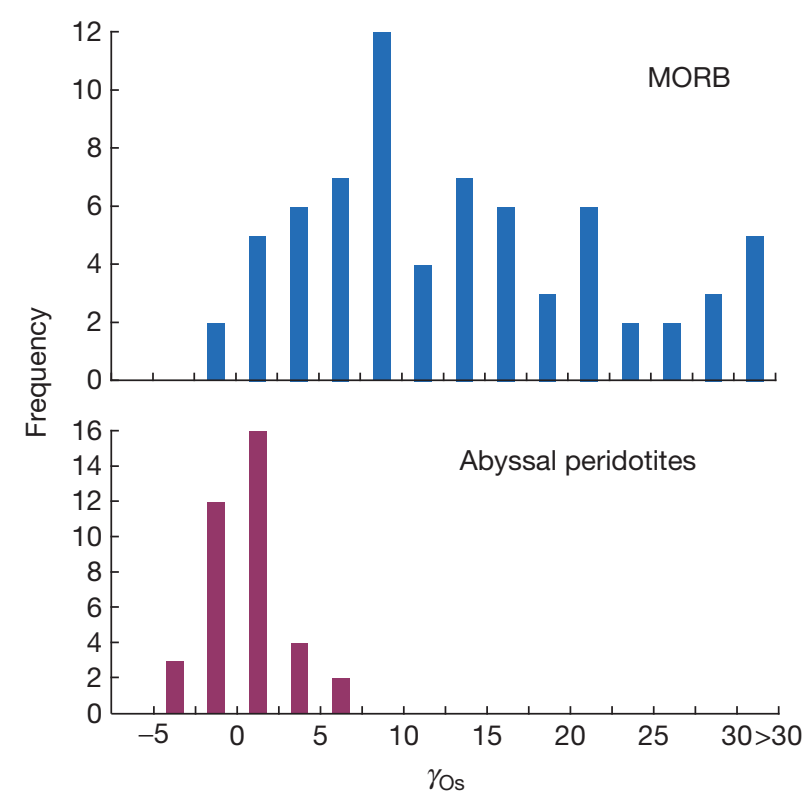

Figure 13 Comparison of Os isotope ratios in MORB and abyssal peridotites. $\gamma_{0 s}$ is higher in MORB than in the peridotites, the presumed source of MORB magmas. $\gamma_{0 s}$ is calculated as $\gamma_{0 s}=\left[\left({ }^{187} 0 \mathrm{~s} /{ }^{188} \mathrm{Os}\right) /\right.$ $0.129-1] \times 100$.

1994), although the peridotites do extend to somewhat more depleted Nd isotopic compositions (Warren et al., 2009). Three factors may account for this difference: postmelting radiogenic ingrowth, contamination by continent-derived Os in seawater or sediments, and Os isotopic disequilibrium between melts and solids.

${ }^{187} \mathrm{Re} /{ }^{188}$ Os in MORB often exceed 1000, compared to $<1$ in abyssal peridotites. Radiogenic ingrowth of ${ }^{187}$ Os becomes significant in as little as $100 \mathrm{ka}$ or less for MORB with such high ${ }^{187} \mathrm{Re} /{ }^{188} \mathrm{Os}$. This effect alone, however, seems inadequate to explain the radiogenic ${ }^{187} \mathrm{Os} /{ }^{188} \mathrm{Os}$ in MORB. Although Os concentrations in seawater are extremely low, Os is strongly taken up by $\mathrm{Fe}-\mathrm{Mn}$ oxyhydroxides that form crusts on basalts, and because of its extremely radiogenic composition $\left({ }^{187} \mathrm{Os} /{ }^{188} \mathrm{Os} \sim 1.06 ; \gamma_{\mathrm{Os}} \sim 720\right)$, even small amounts of this material will shift the isotopic compositions of basalt (e.g., Roy-Barman et al., 1998). Re can also be taken up by basalts during hydrothermal alteration, which will, in turn, quickly lead to radiogenic Os isotopic compositions (Reisberg et al., 2008). Thus, assimilation of either weathered or hydrothermally altered crust by MORB magma will also increase ${ }^{187} \mathrm{Os} /{ }^{188}$ Os. Roy-Barman et al. (1998) reported a correlation between ${ }^{187} \mathrm{Os} /{ }^{188} \mathrm{Os}$ and $\delta^{11} \mathrm{~B}$ in support of this interpretation. As they note, however, even those samples with the lowest $\delta^{11} \mathrm{~B}$, indicative of the least contamination, had ${ }^{187} \mathrm{Os} /{ }^{188}$ Os higher than typical peridotite values. A third possibility is that Os isotopic equilibrium is not achieved during the melting that generates MORB (e.g., Brandon et al., 2000). If so, it appears that lithologies or phases with high Re/Os and radiogenic ${ }^{187} \mathrm{Os} /{ }^{188} \mathrm{Os}$ preferentially contribute to melt production, while phases with low Re/Os and unradiogenic ${ }^{187} \mathrm{Os} /{ }^{188} \mathrm{Os}$ fail to fully equilibrate with the melt. This interpretation is supported by work of Burton et al. (1999), who showed that silicate minerals and interstitial sulfides in a Kilbourne Hole peridotite were in isotopic equilibrium with each other but were out of equilibrium with sulfide inclusions inside silicates and which had much less radiogenic Os.

Os isotope ratios in MORB show statistically significant correlations with $\mathrm{Sr}, \mathrm{Nd}$, and $\mathrm{Pb}$ isotope ratios. Indeed, $\gamma_{\mathrm{Os}}$ correlates better with ${ }^{87} \mathrm{Sr} /{ }^{86} \mathrm{Sr}(r=-0.42, n=62)$ and $\varepsilon_{\mathrm{Nd}}$ $(r=-0.46, n=56)$ than does ${ }^{206} \mathrm{~Pb} /{ }^{204} \mathrm{~Pb} . \gamma_{\mathrm{Os}}$ also correlates with ${ }^{206} \mathrm{~Pb} /{ }^{204} \mathrm{~Pb}(r=-0.63, n=49)$, although this correlation is almost entirely controlled by samples with anomalously radiogenic Os and unradiogenic $\mathrm{Pb}$ from the South Atlantic and Indian Oceans. Nevertheless, these correlations, particularly that with $\varepsilon_{\mathrm{Nd}}$ because it is insenstitive to weathering and alteration, demonstrate that, regardless of contamination or disequilibrium effects, Os isotope ratios do contain information about the mantle source of MORB (Figure 14).

Variations in stable isotope ratios result from chemical processes, specifically from a reduction in free energy that results when the heavier isotope of an element preferentially enters the phase in which it is more strongly bonded. The magnitude of these isotopic fractionations varies approximately inversely with the square of temperature, so that at magmatic temperatures the fractionations are generally quite small. Not surprisingly then, stable isotope ratios in fresh MORB are fairly uniform, particularly when compared with variations observed in these ratios in materials formed or modified at low temperatures at the surface of the Earth. Stable isotope ratios are sensitive to processes such as assimilation of sediment and hydrothermally altered oceanic crust and weathering (e.g., Davis et al., 1998; Muehlenbachs and Clayton, 1972), but such samples have been excluded to the extent possible in the dataset assembled for this review. In contrast to the radiogenic isotope ratios, stable isotope ratios show few systematic relationships. $\delta^{18} \mathrm{O}$ and $\delta^{34} \mathrm{~S}$ do show statistically significant negative correlations with $\mathrm{Mg}$ number, but the $\delta^{34} \mathrm{~S}$ data are so sparse that the latter correlation is questionable. The increase of $\delta^{18} \mathrm{O}$ with decreasing $\mathrm{Mg}$ number is modest, less than $1 \%$ across the entire spectrum of compositions, consistent with earlier studies (e.g., Muehlenbachs and Byerly, 1982). Wanless et al. (2011) argued that the weaker than expected correlation of $\delta^{18} \mathrm{O}$ with $\mathrm{MgO}$, particularly among the rare andesitic and dacitic lavas found along mid-ocean ridges, was due to assimilation of hydrothermally altered oceanic crust, which has low $\delta^{18} \mathrm{O}$. There are no statistically significant correlations between stable and radiogenic isotope ratios in this dataset, although this may, in some cases, reflect the paucity of data. Elliott et al. (2006) found correlations between $\delta^{7} \mathrm{Li}$ and $\mathrm{Sr}$ and $\mathrm{Nd}$ isotope ratios among a small number of samples from the EPR, but there is no correlation between these in the overall MORB dataset.

\subsubsection{Regional Variations in MORB Composition}

\subsection{Regional isotopic variations}

Regional variations in the isotope geochemistry of MORB, apparent in Figures 9-12, are further illustrated in Figure 15, which shows global MORB isotope compositions from the 'continuous' part of the mid-ocean ridge system as a function of angular distance from the northernmost sample, as calculated by Meyzen et al. (2007). Large-scale along-axis 

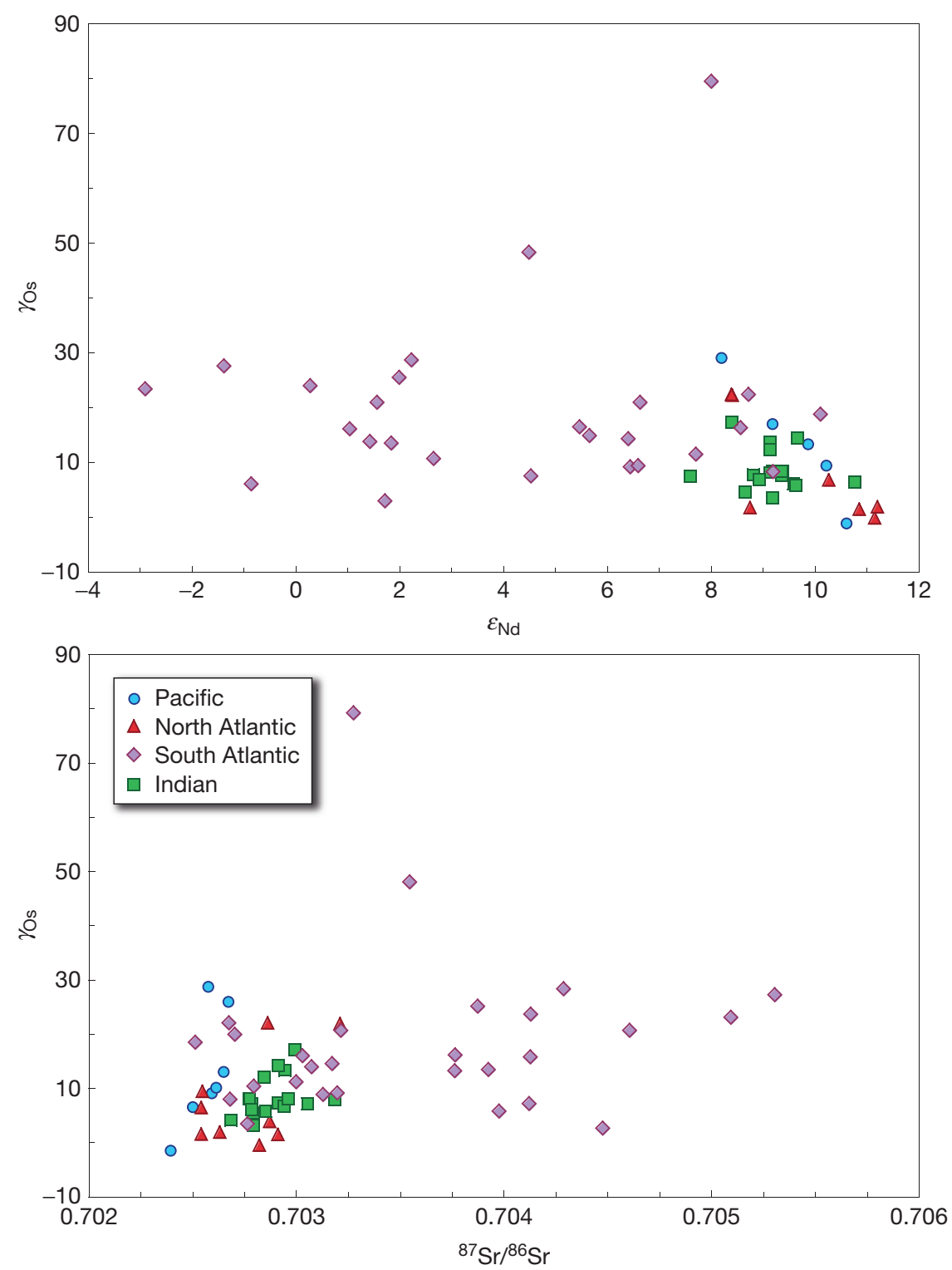

Figure $14 \gamma_{0 s}$ in MORB plotted against $\varepsilon_{N d}$ and ${ }^{87} \mathrm{Sr} /{ }^{86} \mathrm{Sr}$. Correlations in both plots are statistically significant. Much of the total variation in all three isotope ratios occurs in samples from the South Atlantic. See Figure 9 for location boundaries.

variations, many of which are related to oceanic islands and mantle plumes, dominate the global variation, particularly in the Atlantic and Indian oceans. There is broad similarity in isotope ratios of MORB from all regions, but there are systematic, but sometimes subtle, variations between ocean basins. The most notable of these are the differences between Indian Ocean MORB and MORB from other regions. Indian Ocean MORB have low ${ }^{206} \mathrm{~Pb} /{ }^{204} \mathrm{~Pb}$ and high ${ }^{207} \mathrm{~Pb} /{ }^{204} \mathrm{~Pb}$ and ${ }^{208} \mathrm{~Pb} /{ }^{204} \mathrm{~Pb}$ for a given ${ }^{206} \mathrm{~Pb} /{ }^{204} \mathrm{~Pb}$ and high ${ }^{87} \mathrm{Sr} /{ }^{86} \mathrm{Sr}$ (Dupré and Allègre, 1983). Hart (1984) used these latter characteristics to define what he called the DUPAL anomaly, which encompasses the South Atlantic and Indian oceans. MORB, as well as oceanic island basalts (OIB), from this region are characterized by high ${ }^{208} \mathrm{~Pb}$ and high ${ }^{207} \mathrm{~Pb}$, which Hart defined as

$$
\Delta 8 / 4=\left[{ }^{208} \mathrm{~Pb} /{ }^{204} \mathrm{~Pb}-{ }^{208} \mathrm{~Pb} /{ }^{204} \mathrm{~Pb}_{\mathrm{NHRL}}\right] \times 100
$$

$$
\Delta 7 / 4=\left[{ }^{207} \mathrm{~Pb} /{ }^{204} \mathrm{~Pb}-{ }^{207} \mathrm{~Pb} /{ }^{204} \mathrm{~Pb}_{\mathrm{NHRL}}\right] \times 100
$$

where NHRL is the Northern Hemisphere Regression Line, that is, the line defined by Northern Hemisphere $\mathrm{Pb}$ isotope ratios given by

$$
\begin{aligned}
& { }^{208} \mathrm{~Pb} /{ }^{204} \mathrm{~Pb}_{\mathrm{NHRL}}=15.627+1.209{ }^{206} \mathrm{~Pb} /{ }^{204} \mathrm{~Pb} \\
& { }^{207} \mathrm{~Pb} /{ }^{204} \mathrm{~Pb}_{\mathrm{NHRL}}=13.491+0.1804{ }^{206} \mathrm{~Pb} /{ }^{204} \mathrm{~Pb}
\end{aligned}
$$

High ${ }^{4208} \mathrm{~Pb}$ and low $\varepsilon_{\mathrm{Nd}}$ and $\varepsilon_{\mathrm{Hf}}$ relative to ${ }^{87} \mathrm{Sr} /{ }^{86} \mathrm{Sr}$ distinguish South Atlantic MORB from North Atlantic MORB (Figures 9 and 11). Both South Atlantic and Indian MORB share high $\Delta 8 / 4$ and $\Delta 7 / 4$; Indian MORB is distinguished from South Atlantic MORB by particularly low ${ }^{206} \mathrm{~Pb} /{ }^{204} \mathrm{~Pb}$ and high ${ }^{208} \mathrm{~Pb} /{ }^{204} \mathrm{~Pb}$, and higher $\varepsilon_{\mathrm{Nd}}$ and $\varepsilon_{\mathrm{Hf}}$ relative to ${ }^{87} \mathrm{Sr} /{ }^{86} \mathrm{Sr}$ compared to South Atlantic MORB. Pacific MORB overlap 


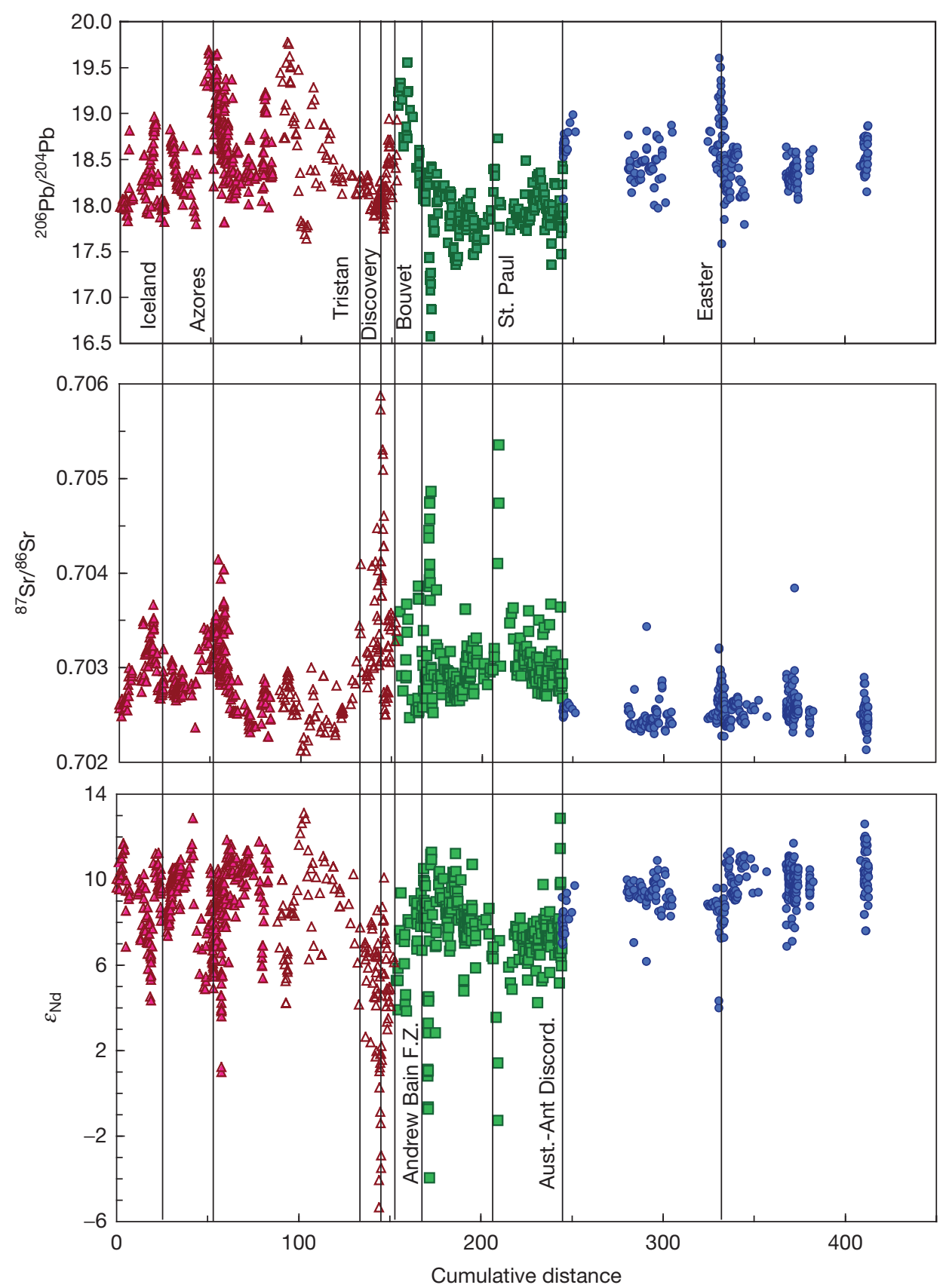

Figure $15 \varepsilon_{\mathrm{Nd}}{ }^{87} \mathrm{Sr} /{ }^{86} \mathrm{Sr}$, and ${ }^{206} \mathrm{~Pb} /{ }^{204} \mathrm{~Pb}$ from the 'continuous' part of the mid-ocean ridge system as a function of angular distance from the northernmost sample, as calculated by Meyzen et al. (2007). The ' 0 ' point is the location of the northernmost sample site of the Gakkel Ridge at $85.64^{\circ} \mathrm{N}$, $85.05^{\circ} \mathrm{E}$.

Atlantic MORB in $\mathrm{Pb}$ isotopes, but have low ${ }^{87} \mathrm{Sr} /{ }^{86} \mathrm{Sr}$ for a given $\varepsilon_{\mathrm{Nd}}$ (Ito et al., 1987; White et al., 1987) and low $\varepsilon_{\mathrm{Hf}}$ for a given $\varepsilon_{\mathrm{Nd}}$.

Boundaries between these domains can be sharp or diffuse. Figure 16 shows isotopic variations at two of these domain boundaries: the South Atlantic/Indian and Indian/Pacific. The latter is located at a small nontransform discontinuity of the Southeast Indian Ridge within the Australian-Antarctic discordance and is quite sharp (Klein et al., 1988; Pyle et al., 1992). By contrast, the boundary between the South Atlantic and Indian domains, which occurs west of the Andrew Bain Fracture Zone (the Antarctic-Nubian, Somalian triple junction) located at $30^{\circ} \mathrm{E}$ on the SWIR, is gradual (Meyzen et al., 2007). The boundary between the North and South Atlantic provinces, located near $23^{\circ} \mathrm{S}$, is also diffuse.

The existence of a small number of isotopic domains reflects a fundamental organization of mantle convection. The isotopic differences reflect differing chemical histories of these regions, which, in turn, reflect physical processes such as melt extraction and addition of material from crustal or other 

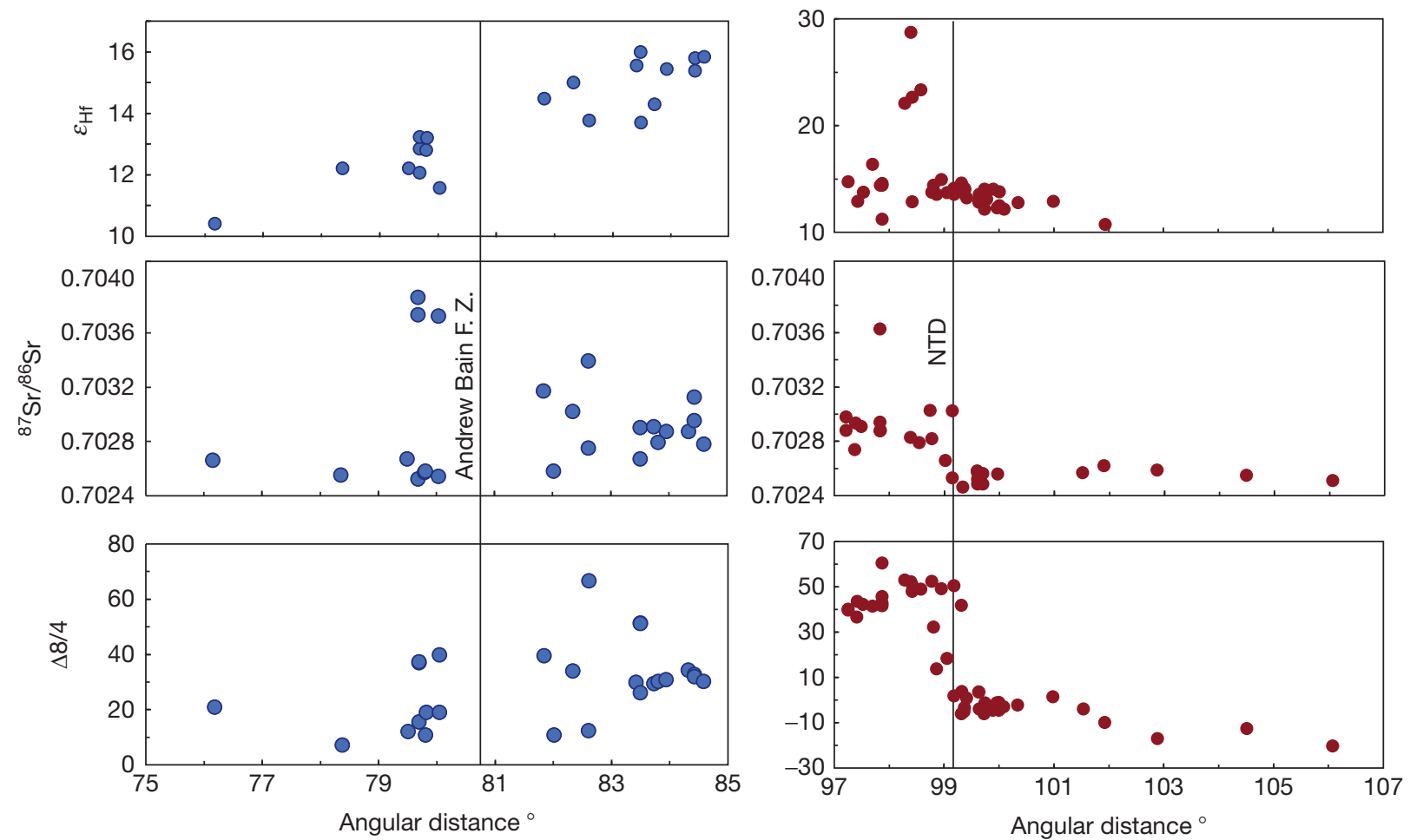

Figure 16 Details of along-ridge isotopic variations at the boundary between the South Atlantic and Indian domains (left) and between the Indian and Pacific domains (right). In the right, NTD is the unnamed nontransform discountinuity in the ridge at the isotopic boundary.

mantle reservoirs. Upper mantle asthenosphere is continually consumed in the production of oceanic crust and lithosphere; this consumption must be approximately balanced by flow of material into the asthenosphere, either from below or from subduction zones. Yamamoto et al. (2007) have argued that the asthenosphere is replenished by mantle plumes. In the North Atlantic, oceanic islands have isotopic signatures that either overlap the North Atlantic MORB field, or plot close to extensions of it. This suggests that the mantle plumes responsible for these islands may be the primary mechanism by which the North Atlantic asthenosphere is replenished. However, this is only partly true in the South Atlantic, and generally not true in the Indian Ocean, as Meyzen et al. (2007) have pointed out. The more extreme isotopic compositions, particularly the unradiogenic $\mathrm{Pb}$, have no analog in the compositions of oceanic islands of these regions. Meyzen et al. (2007) have suggested that these regions are replenished by flow from the African 'superplume,' which manifests itself as a large region of slow seismic velocity extending through the upper mantle. This possibility is supported by the analysis of shear-wave splitting in the circum-Africa region, which suggests radial outward flow from beneath Africa at the base of the lithosphere (Behn et al., 2004). The case of the Pacific is less clear-cut. Near-ridge plumes, such as the Galapagos and Easter-Sala y Gomez, have isotopic compositions that lie within or on an extension of the Pacific MORB array, but central and South Pacific plumes, such as Hawaii, the Society Islands, and Samoa, plot well off the Pacific MORB array (e.g., White, 2010). One possible explanation is that the Pacific plume flux is small compared to the volume of the Pacific asthenosphere, so that plumes have minimal compositional influence on it.
Batiza (1984), and more recently Rubin and Sinton (2007), suggested that isotopic variability is inversely related to spreading rate. Both suggested this results from more effective homogenization of heterogeneous primary melt batches in magma chambers of fast-spreading ridges. At the local scale, individual flows do seem to be more homogeneous at fast-spreading ridges (Rubin and Sinton, 2007; Rubin et al., 2001, 2009) clearly demonstrating that mid-ocean ridge magma chambers act to homogenize melts passing through them, particularly when spreading rates and magma fluxes are high. Nevertheless, as Figure 17 shows, there is no systematic relationship between spreading rate and isotopic variability at spreading rates below about $80 \mathrm{~mm}_{\text {year }}{ }^{-1}$. The greatest variability occurs on the Chile, Southern Mid-Atlantic, and Southwest Indian ridges. Data on the Chile Ridge is sparse (only $25{ }^{87} \mathrm{Sr} /{ }^{86} \mathrm{Sr}$ analyses), comes mostly from segments near the Chile Margin Triple junction, and most of the heterogeneity is confined to a single segment (Sturm et al., 1999). It is unclear whether this variability characterizes the entire Chile Ridge. With the exception of the Chile Ridge, Pacific spreading centers show similar variability despite a factor of 3 variation in the spreading rate. New isotopic data from the very slow-spreading ridges of the Arctic region, the Gakkel, the Kolbeinsey, and Mohns ridges, are certainly more isotopically heterogeneous than the Pacific spreading centers, but less heterogeneous than the faster spreading ridges in the Indian and the Central and South Atlantic. Furthermore, the slow-spreading northern MAR (between Iceland and the Azores triple junction) is nearly as homogeneous as the Pacific spreading centers.

Two other factors suggest that magma chamber processes are not solely responsible for differences in isotopic variability. 


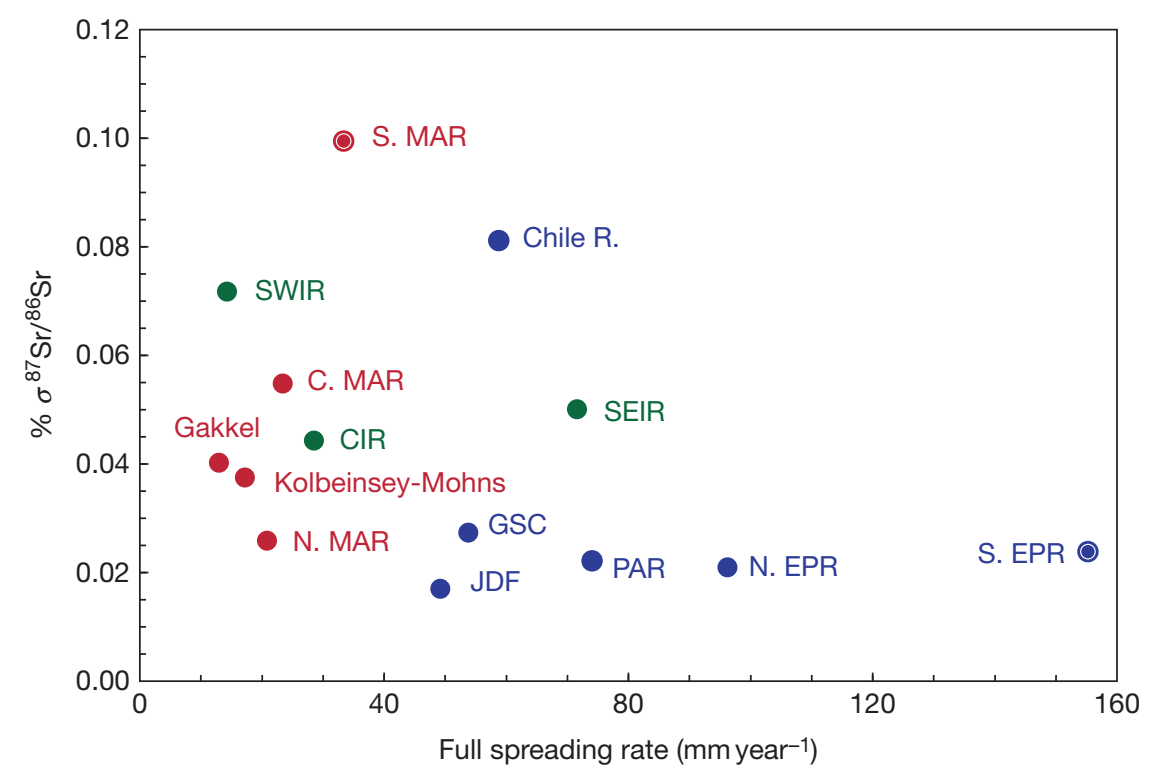

Figure 17 Standard deviation (in percent) of ${ }^{87} \mathrm{Sr} /{ }^{86} \mathrm{Sr}$ for samples from various mid-ocean ridges as a function of spreading rate. MAR, Mid-Atlantic Ridge; SWIR, Southwest Indian Ridge; CIR, Central Indian Ridge; SEIR, Southeast Indian Ridge; JDF, Juan de Fuca Ridge; GSC, Galapagos Spreading Center; PAR, Pacific-Antarctic Ridge; EPR, East Pacific Rise.

First, there is no correlation between $\mathrm{MgO}$ and isotopic variability above $\mathrm{MgO}$ of about $3 \mathrm{wt} \%$ (MORB are more isotopically uniform below $3 \mathrm{wt} \% \mathrm{MgO}$, which may indeed be due to magma chamber homogenization; but all such lavas come from only three localities on the GSC). In addition, Rubin and Sinton (2007) found no correlation between Mg\# and isotopic variability. Second, restricting the dataset to only samples with $\mathrm{MgO}>8 \mathrm{wt} \%$ does not substantially change the overall pattern presented in Figure 17. It seems clear that steady-state magma chambers on fast- and intermediatespreading ridges do work to homogenize magmas passing through them, but this effect does not entirely obscure real differences in isotopic variability. Figure 17 suggests that the upper mantle beneath the South Atlantic and Indian oceans is intrinsically more heterogeneous than the upper mantle elsewhere, while the mantle beneath most of the Pacific may be intrinsically less heterogeneous than elsewhere.

\subsection{Regional major element variations}

On the scale of hundreds of kilometers, the effect of mantle plumes on MORB isotopic and trace element composition has been amply demonstrated, particularly through the work of Schilling and colleagues (e.g., Hart et al., 1973; Schilling, 1973; Schilling et al., 1983; White and Schilling, 1977). The influence of on- or near-ridge plumes, such as Iceland, the Azores, Tristan da Cunha, Discovery Seamount, St Paul Amsterdam, and Easter-Sala y Gomez, is amply apparent in Figure 15. The effect of mantle plumes on the oceanic crust, however, goes well beyond merely isotopic and trace element compositions. Where spreading centers pass near or over mantle plumes, such as Iceland, the Azores, the Galapagos, and Afar, ridges are typically elevated and crustal thickness is greater (e.g., White et al., 1992). Variations in major element chemistry of both MORB and abyssal peridotites also correlate with the proximity of mantle plumes. The connection appears to be that of mantle temperature and extent of melting (Dick et al., 1984). This was best demonstrated by the work of Klein and Langmuir (1987), who showed that correlations between major element chemistry, crustal thickness, and axial depth relate to the mantle temperature.

Variations in major element geochemistry are dominated by the effects of fractional crystallization and partial melting. While fractional crystallization also affects trace elements, incompatible trace element variations resulting from this process tend to be small compared to variations resulting from differing extents of melting and mantle source heterogeneity. Thus, to use major elements to assess mantle temperature requires first correcting for the effects of fractional crystallization. Klein and Langmuir (1987) did this by projecting the composition of each magma back along a presumed liquid line of descent to $8 \mathrm{wt} \% \mathrm{MgO}$. The calculated $\mathrm{Na}_{2} \mathrm{O}$ value at $8 \mathrm{wt} \% \mathrm{MgO}$ is thus referred to as $\mathrm{Na}_{8.0}$. In theory, if the liquid line of descent is known for any major or trace element, a 'fractionationcorrected' value of the element can be calculated (producing calculated values of, e.g., $\mathrm{Fe}_{8.0}, \mathrm{Al}_{8.0}, \mathrm{~K}_{8.0}, \mathrm{Ce}_{8.0}$, etc.). The few elements for which the slope of the liquid line of descent changes sign as the fractionating phases change, such as $\mathrm{CaO}$ (due to the appearance of Ca-bearing phases on the liquidus), are more difficult to model in this way and therefore produce less reliable fractionation-corrected values. Nevertheless, most major and trace elements display fairly regular liquid lines of descent and their fractionation-corrected values reveal relative differences in parental magma compositions that result from differences in melting systematics or source composition. Figure 18 shows the example of $\mathrm{Na}_{8.0}$ and $\mathrm{Fe}_{8.0}$ calculated from samples from a number of different regions.

Corrected for fractional crystallization, major elements correlate in revealing and predictable ways. In general, regions with low mean $\mathrm{Na}_{8.0}$ are also characterized by high mean $\mathrm{Fe}_{8.0}$ (as well as low $\mathrm{Si}_{8.0}$ and $\mathrm{Al}_{8.0}$, and higher $\mathrm{Ca}_{8.0}$ ), while other regions exhibit the opposite characteristics, as well as a continuum of compositions in between (Klein and Langmuir, 

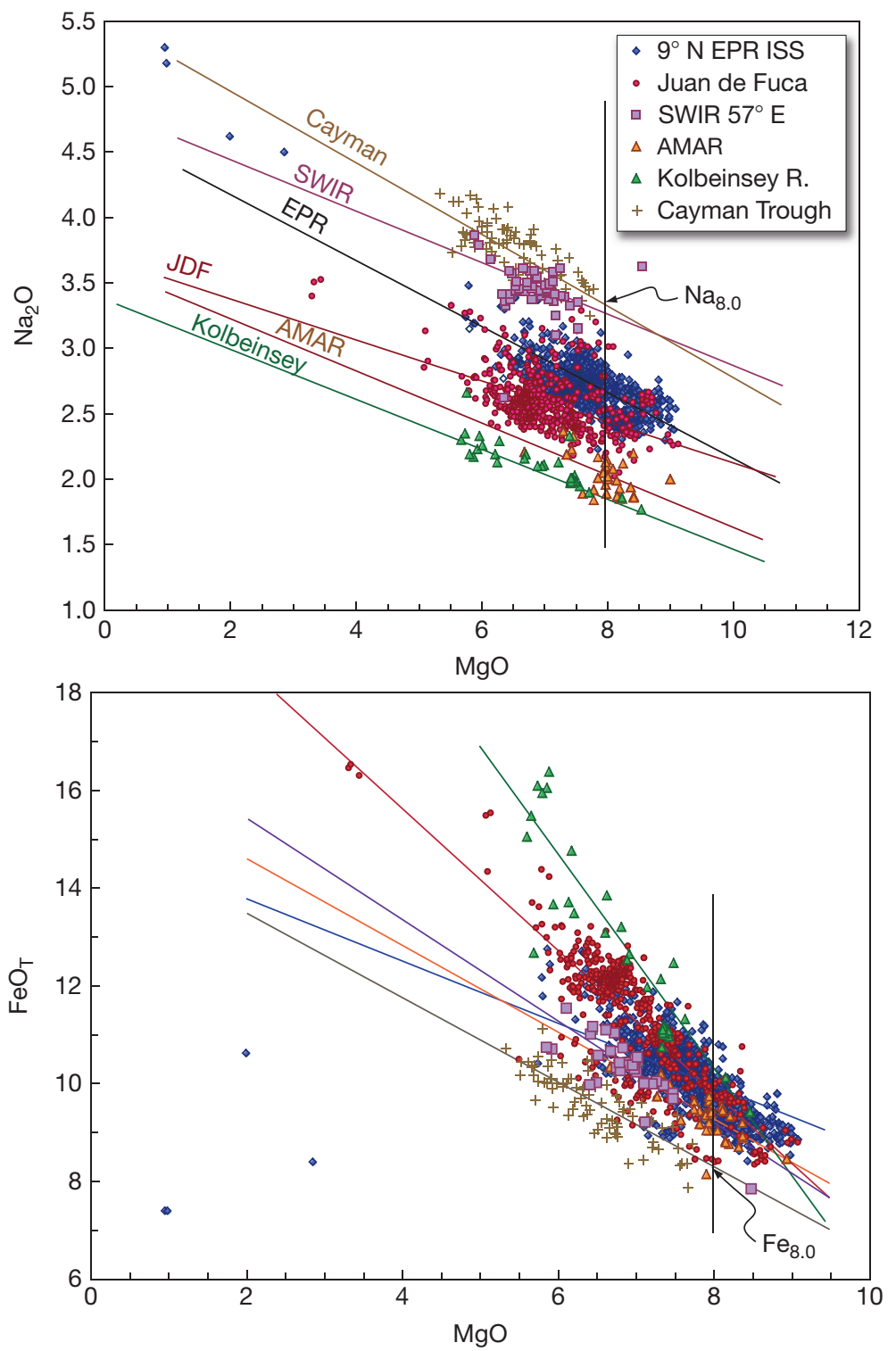

Figure $18 \mathrm{Na}_{2} \mathrm{O}$ and $\mathrm{FeO}$ versus $\mathrm{MgO}$ in $\mathrm{MORB}$ from various regions of the mid-ocean ridge system plot along liquid lines of descent of varying slopes. $\mathrm{Fe}_{8.0}$ and $\mathrm{Na}_{8.0}$ are the values of $\mathrm{Na}_{2} \mathrm{O}$ and $\mathrm{FeO}$, respectively, of the lines at $8.0 \mathrm{wt} \% \mathrm{MgO}$. The AMAR region is located at $37-38^{\circ} \mathrm{N}$ on the Mid-Atlantic Ridge; EPR, the Integrated Study Site (ISS) between the 9N OSC and Clipperton transform on the East Pacific Rise; JDF, Juan de Fuca Ridge; SWIR, Southwest Indian Ridge.

1987; Langmuir et al., 1992). Furthermore, these major element variations correlate with physical characteristics of the ridge axis from which they were recovered. Regional averages of $\mathrm{Na}_{8.0}$ and $\mathrm{Fe}_{8.0}$, for example, show a positive and an inverse correlation, respectively, with the average ridge depth from which the lavas were recovered (Figure 19). In addition, $\mathrm{Na}_{8.0}$ correlates inversely with seismically and geologically determined estimates of the crust thickness in each region (Figure 20). Thus, some of the most fundamental physical and chemical parameters studied at ocean ridges suggest a common origin in their variability.

The chemical systematics can be understood as the interplay of two main factors affecting the style of mantle melting: the extent of melting and the pressure of melting. Elements such as sodium are moderately incompatible during melting of mantle minerals ( $D \sim 0.02-0.03$ ), and therefore will be concentrated in the melt at small extents of melting. Iron varies in the melt as a function of the pressure of melting (e.g., Langmuir and Hanson, 1980). Thus, the inverse correlation between mean $\mathrm{Na}_{8.0}$ and mean $\mathrm{Fe}_{8.0}$ suggests that there is a positive correlation between the mean extent of melting and the mean pressure of melting. This is readily understood with reference to Figure 4: if melting begins at great depth, both the mean extent and mean depth of melting will be greater than when melting begins at a shallower depth. The correlations shown in Figure 19 suggest that melts from bathymetrically deep ridges tend to be produced by smaller extents of melting (high $\mathrm{Na}_{8.0}$ ) and low pressure (low $\mathrm{Fe}_{8.0}$ ), while melting beneath shallower ridges leads to larger extents of melting (low $\mathrm{Na}_{8.0}$ ) at higher pressures of melting (high $\mathrm{Fe}_{8.0}$ ). A region that 


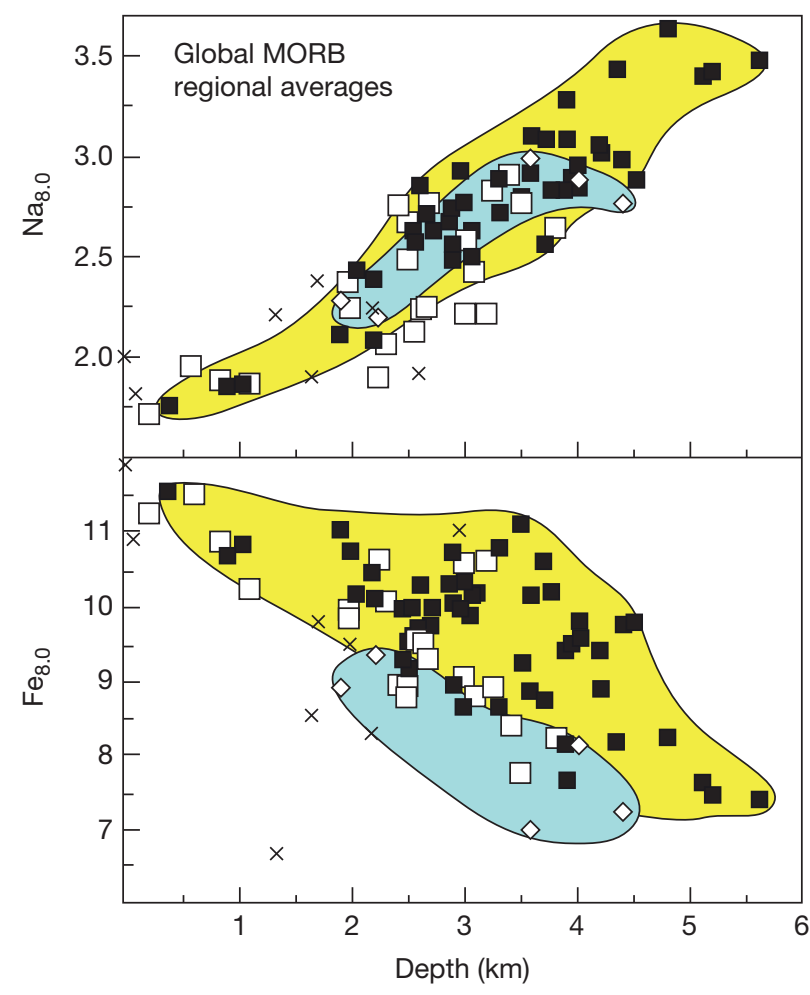

Figure 19 Regional average $\mathrm{Fe}_{8.0}$ and $\mathrm{Na}_{8.0}$ as a function of regional average axial depth in the mid-ocean ridge system. This figure is the same as Figure 2 in Klein and Langmuir (1987), except all analyses have been recalculated to sum to $100 \%$ (all iron as $\mathrm{Fe}$ ) and have been corrected for interlaboratory differences. Solid squares are MORB from 'normal' ridge segments; diamonds are from back-arc basins; open squares are from ridges influenced by the Galapagos, Azores, Jan Mayen, Tristan, Iceland, and Bouvet hotspots; X's are from ridge segments immediately adjacent to these hotspots. Light blue field encompasses back-arc basin basalts; yellow field encompasses normal ridge basalts.

experiences a small extent of melting would have thinner oceanic crust than a region that experiences a larger extent of melting. This, in turn, would lead to the observed correlation between a chemical parameter indicative of the extent of melting (e.g., $\mathrm{Na}_{8.0}$ ) and crustal thickness seen in Figure 20. Furthermore, if the crust is isostatically compensated, thinner crust would lead to greater ridge depth below sea level, and therefore the correlation between chemistry and axial depth (Figure 19).

The global correlations among regional averages of major elements can, in turn, be related to lateral variations in the subsolidus temperature (potential temperature) of the mantle (Klein and Langmuir, 1987; McKenzie and Bickle, 1988). As pointed out in an earlier section, hotter mantle intersects the solidus deeper and melts more upon ascent than cooler mantle temperatures (Figures 4 and 5), leading to the associated correlations with axial depth and crustal thickness.

A number of studies have used the major element (and trace element) systematics of MORB to constrain the mean extent and mean pressure of melting, as well as potential temperature, and the depth and temperature of intersection of the mantle solidus, both for a given region and for the global ocean ridge system as a whole (e.g., Asimow and Langmuir,
2003; Asimow et al., 2001; Herzberg et al., 2007; Kinzler and Grove, 1992; Klein and Langmuir, 1987; Langmuir et al., 1992; McKenzie and Bickle, 1988; Putirka et al., 2007). A thorough evaluation of these parameters requires numerous assumptions that are subject to uncertainty. These include, for example, assumptions about the physical form of the melting regime, including variables such as active versus passive upwelling and variations in the final depth of melting (e.g., Plank and Langmuir, 1992; Scott and Stevenson, 1989); the processes of melt extraction and mixing (e.g., batch vs. fractional melting, percentages of melt retention, incomplete focusing of melt); a melt generation function; and the effects of source mineralogy and composition, including volatile species (e.g., Asimow and Langmuir, 2003; Asimow et al., 2001; Langmuir et al., 1992; Niu et al., 2001). Earlier studies, noted above, estimated the global range in the pressure of intersection of the solidus as $\sim 1.5-3.6 \mathrm{GPa}$, in the temperature of intersection of the solidus as $\sim 1300-1550{ }^{\circ} \mathrm{C}$, in the mean extent of melting as $\sim 8-22 \%$, and in the mean pressure of melting as $\sim 0.5-$ 1.6 GPa. More recently, Putirka et al. (2007), using olivine geothermometry, concluded that the average mantle potential temperature beneath mid-ocean ridges was $1454{ }^{\circ} \mathrm{C}$ and that most MORB were generated within a narrow range of $\pm 34^{\circ} \mathrm{C}$. They estimated the potential temperature beneath Iceland to be $1616^{\circ} \mathrm{C}$, and the overall temperature range from the coldest mid-ocean ridges to Iceland to be $215-246^{\circ} \mathrm{C}$, in good agreement with the $250{ }^{\circ} \mathrm{C}$ range estimated by Klein and Langmuir (1987). They suggested that the effects of $\mathrm{H}_{2} \mathrm{O}$ could reduce the estimated temperature range and lower the mean temperature estimate by $25^{\circ} \mathrm{C}$. Herzberg et al. (2007) concluded that melting begins for most MORB in the range of 2.0-3.0 GPa at potential temperatures of $1280-1400{ }^{\circ} \mathrm{C}$, but under Iceland the mantle is hotter (potential temperature of $1460{ }^{\circ} \mathrm{C}$ ) and melting begins at greater pressure (3.6 GPa). Gregg et al. (2009) calculated a mantle potential temperature of $1350^{\circ} \mathrm{C}$ from compositions of basalts erupted in the Siqueiros Fracture Zone at $9^{\circ} \mathrm{N}$ on the EPR.

Niu and $\mathrm{O}^{\prime}$ Hara (2008) showed that regional average $\mathrm{Mg}$ numbers also correlate with axial depth. They argue that the procedure used by Klein and Langmuir (1987) did not completely correct for fractional crystallization and that, when this correction is done (to liquid $\mathrm{Mg}$ numbers of 72), the corrected $\mathrm{FeO}$ concentrations (which they call $\mathrm{Fe}_{72}$ ) show a much smaller range of variation and shallower correlation with axial depth. From this, they argue that the range of potential temperatures beneath mid-ocean ridges (excluding Iceland and ridges less than $250 \mathrm{~m}$ deep) is no more than $70^{\circ} \mathrm{C}$, which is too small, they argue, to account for the variation in axial depth. Using their approach, however, the range of fractionationcorrected $\mathrm{Na}_{2} \mathrm{O}$ concentrations remains similar to that found by Klein and Langmuir (1987). They argue that rather than temperature, mantle fertility controls both axial depth and $\mathrm{Na}_{2} \mathrm{O}$ : more fertile mantle is richer in $\mathrm{Na}_{2} \mathrm{O}$ and is denser, resulting in greater axial depth.

The difficulty with this interpretation is that more fertile mantle should melt more extensively than more depleted mantle if potential temperature is nearly constant, as Niu and O'Hara (2008) assume. In this case, axial depth should correlate inversely with crustal thickness. As Figure 21 shows, the opposite is true: crust is thinnest where axial depth is greatest. 


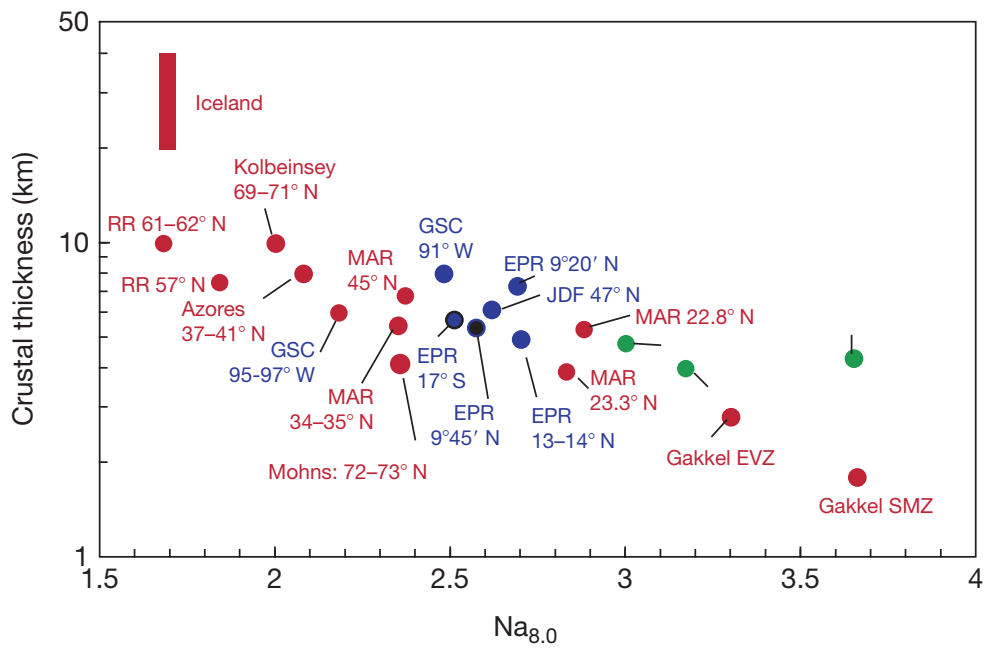

Figure 20 Regional averages of seismically determined crustal thickness versus $\mathrm{Na}_{8.0}$ (the $\mathrm{Na}_{2} \mathrm{O}$ content of basalts normalized to 8 wt\% $\mathrm{MgO}$; Klein and Langmuir, 1987). Sources for seismic determinations of crustal thickness are from Klein and Langmuir (1987), augmented and/or superseded by the following: Smallwood and White (1998), Navin et al. (1998), Darbyshire et al. (2000), Detrick et al. (2002), Muller et al. (1999), Hooft et al. (2000), Fowler and Keen (1979), Canales et al. (1998), McClain and Lewis (1982), Kodaira et al. (1997), Klingelhöfer et al. (2000), Jokat et al. (2003), Michael et al. (2003), Holmes et al. (2008). RR, Reykjanes Ridge; MAR, Mid-Atlantic Ridge; EPR, East Pacific Rise; GSC, Galapagos Spreading Center; JDF, Juan de Fuca Ridge; AAD, Australian-Antarctic discordance; SWIR, Southwest Indian Ridge. EVZ and SMZ are the Eastern Volcanic and Sparsely Magmatic zones of the Gakkel Ridge, respectively.

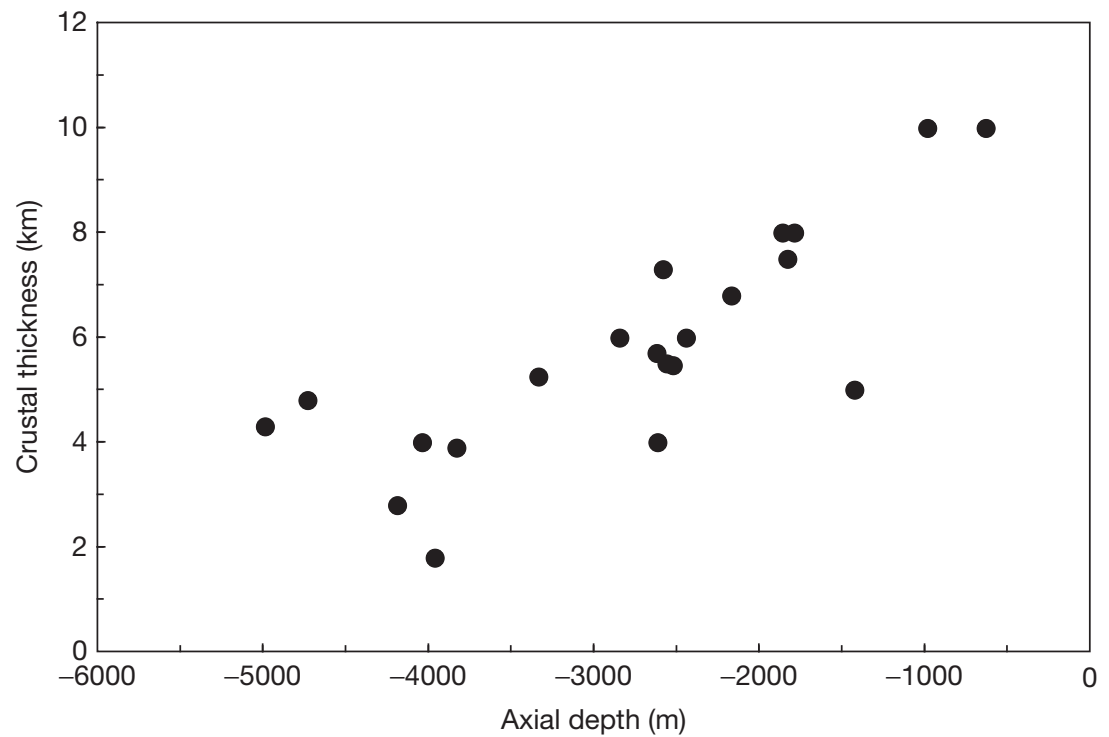

Figure 21 Relationship between axial depth and seismically determined crustal thickness along mid-ocean ridges. The thickest crust, and by implication the greatest extents of melting, occur at the shallowest axial depths. Crustal thickness data sources are the same as in Figure $\mathbf{2 0 .}$

Iceland, with thick crust and low $\mathrm{Na}_{2} \mathrm{O}$ concentrations, poses a particular problem for the Niu and $\mathrm{O}^{\prime}$ Hara model, and they concede that they do not have an answer to what they called 'the Iceland paradox.' If, as is generally believed, mantle 'fertility' is largely controlled by extracting basaltic melts and remixing basalt (oceanic crust) back into the mantle, one would expect mantle fertility to correlate with isotope and incompatible trace element ratios. Thus, if mantle fertility rather than mantle potential temperature were to explain the variations in axial depth, one would expect correlations between these ratios and axial depth. Figure 22 shows that there is no correlation between ${ }^{87} \mathrm{Sr} /{ }^{86} \mathrm{Sr}$ and axial depth; other isotope ratios and trace element ratios, such as $\mathrm{La} / \mathrm{Sm}$, correlate with neither axial depth nor crustal thickness. While some of the chemical variability among MORB almost certainly results from variations in mantle fertility or other chemical or mineralogical heterogeneity of the mantle (e.g., Shen and Forsyth, 1995), the weight of current evidence supports the idea that the first-order trends in regional topography, basalt chemistry, and crustal thickness result from mantle temperature variations. Uncertainly remains, however, as to the exact value of mean potential temperature beneath ridges and how much it varies. 


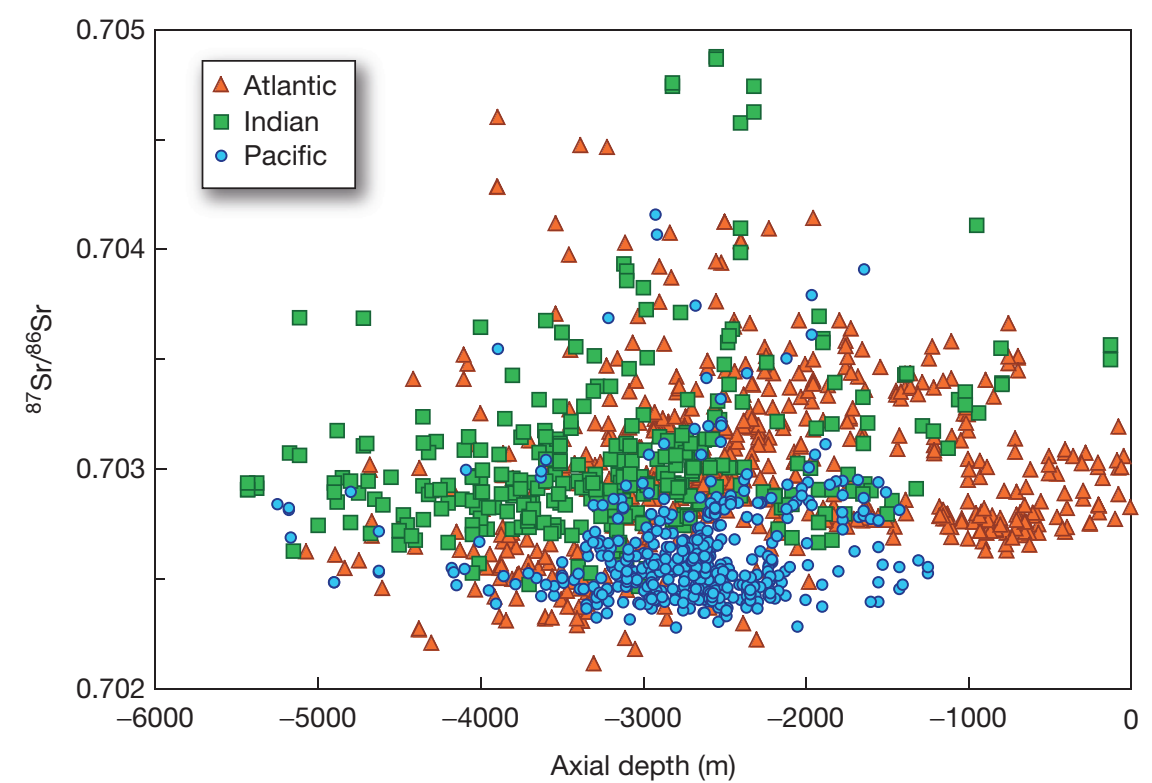

Figure $22{ }^{87} \mathrm{Sr} /{ }^{86} \mathrm{Sr}$ shows no correlation with axial depth; instead maximum values tend to occur at intermediate axial depth. This suggests that mantle composition is not related to axial depth.

\subsubsection{Estimating the Bulk Composition of the Oceanic Crust}

It has been understood at least since the work of O'Hara (1968) that MORB melts are not 'primary melts' in equilibrium with the mantle. Rather, MORB melts have evolved through crystallization from primary parent melts, and the complementary crystal cumulates make up much of the lower crust and may also reside in the upper mantle (see Chapter 4.14). Mg numbers of MORB also provide prima fascia evidence that MORB are evolved magmas. The various average compositions in Table 1 have $\mathrm{Mg}$ numbers of about 60 or a little lower. These compositions would be in equilibrium with olivine having a forsterite content of about $80-85 \%$. Mantle olivine, by contrast, typically has a forsterite content in the range of $90-92 \%$ (see Chapters 3.4 and 3.6), which would be in equilibrium with a melt with an $\mathrm{Mg}$ number of around 72 . Thus, magmas erupted at mid-ocean ridges must have cooled and crystallized olivine, as well as other phases, since leaving the mantle. The bulk composition of the oceanic crust is, thus, the composition of lavas erupted at the surface plus cumulate minerals in the lower crust and upper mantle. The average composition of the oceanic crust should equal the composition of average parental magma extracted from the mantle.

A first-order estimate of the average composition of the overall oceanic crust can be made by attempting to reconstruct the composition of a parental magma that would give rise to an average MORB composition through fractional crystallization. We begin by assuming that parental magmas extracted from the mantle have an $\mathrm{Mg}$ number of 72 ; subsequent compositional evolution during fractional crystallization depends not only on parental composition but also on the pressures at which crystallization occurs, that is, the $P-T$ path. Constraints on the $P-T$ path are sparse. This makes reconstruction of the exact composition of the average parental magma difficult, but a first-order estimate is possible using the $\mathrm{Mg}$ number
Table 7 Major element composition of the bulk oceanic crust

\begin{tabular}{|c|c|c|c|c|c|c|}
\hline & \multirow{2}{*}{$\begin{array}{l}\text { Bulk } \\
\text { crust } \\
\text { (wt\%) }\end{array}$} & \multirow{2}{*}{$\begin{array}{l}\text { Average } \\
\text { MORB } \\
\text { (layer 2) }\end{array}$} & \multicolumn{3}{|c|}{ Lower crust ${ }^{\mathrm{b}}$ (layer 3) } & \multirow[t]{2}{*}{ Cumulate } \\
\hline & & & Mean & $\sigma$ & Median & \\
\hline $\mathrm{SiO}_{2}$ & 50.1 & 50.06 & 50.6 & \pm 1.6 & 51.0 & 48.9 \\
\hline $\mathrm{TiO}_{2}$ & 1.1 & 1.52 & 0.78 & \pm 0.81 & 0.4 & 0.12 \\
\hline $\mathrm{Al}_{2} \mathrm{O}_{3}$ & 15.7 & 15.00 & 16.7 & \pm 2.3 & 16.6 & 16.4 \\
\hline $\mathrm{Fe}_{2} \mathrm{O}_{3}$ & 1.4 & & & & & 0.47 \\
\hline $\mathrm{FeO}$ & 7.1 & & & & & 4.63 \\
\hline $\mathrm{FeO}_{\mathrm{T}}$ & 8.3 & 10.36 & 7.5 & \pm 3 & 6.1 & 5.1 \\
\hline $\mathrm{MnO}$ & 0.11 & 0.19 & 0.14 & \pm 0.05 & 0.1 & 0.03 \\
\hline $\mathrm{MgO}$ & 10.3 & 7.71 & 9.4 & \pm 1.1 & 9.0 & 14.5 \\
\hline $\mathrm{CaO}$ & 11.8 & 11.46 & 12.5 & \pm 1 & 12.6 & 13.46 \\
\hline $\mathrm{Na}_{2} \mathrm{O}$ & 2.21 & 2.52 & 2.35 & \pm 0.45 & 2.4 & 1.34 \\
\hline $\mathrm{K}_{2} \mathrm{O}$ & 0.11 & 0.19 & 0.06 & \pm 0.03 & 0.1 & 0.01 \\
\hline $\mathrm{P}_{2} \mathrm{O}_{5}$ & 0.10 & 0.16 & 0.02 & \pm 0.02 & 0.0 & 0.0 \\
\hline Total & 99.7 & 99.2 & 100.1 & & 98.3 & 99.8 \\
\hline $\mathrm{Mg \#}$ & 72 & 59 & 69 & \pm 10 & 73 & 85 \\
\hline
\end{tabular}

${ }^{a}$ From Table 1.

${ }^{b}$ From Chapter 15, Table 2.

constraint, together with thermodynamics-based numerical models of magma evolution.

The estimated parental MORB magma composition, and therefore bulk oceanic crust composition listed in Tables 7 and 8 , was determined in the following manner. The mean glass composition listed in Table 1 was taken as a starting point (since it presumably represents a liquid composition, whereas bulk-rock compositions do not). A first estimate of the parental magma composition with an $\mathrm{Mg}$ number of 72 was made using the polynomial regression procedure of Niu and O'Hara (2008). This is an empirical approach based on observed trends in MORB glasses. Fractional crystallization of this 
composition was then simulated in v.5 of MELTS (Asimow and Ghiorso, 1998; Ghiorso and Sack, 1995) from its liquidus temperature $\left(1266^{\circ} \mathrm{C}\right.$ at $\left.0.18 \mathrm{MPa}\right)$, until the remaining liquid had an Mg number of 60 (roughly that of the glass). Simulations at a variety of pressures and oxygen fugacities suggested that a pressure of $0.18 \mathrm{GPa}$, which corresponds roughly to the base of the oceanic crust, and an oxygen fugacity fixed at the quartz-magnetite-fayalite buffer produced the daughters most closely matching the average glass composition. Nevertheless, the daughter liquid composition initially calculated using these conditions did not match the average glass composition well, so the composition of the parent was adjusted by increasing or decreasing individual oxide concentrations and the simulation repeated until an optimal result was obtained. The final parental composition listed in Table 7 fractionates to a composition matching the glass composition in Tables 2 and 3 within a few percent for all oxides except $\mathrm{CaO}$ (the daughter liquid is $6 \%$ poorer in $\mathrm{CaO}$ than the average glass composition). This is achieved at a temperature of $1202{ }^{\circ} \mathrm{C}$ after $41 \%$ of the magma had crystallized. Were all the fractionated solid phases to form a single gabbro, it would consist of $13.3 \%$ olivine, $45.5 \%$ plagioclase, $41.0 \%$ clinopyroxene, and $0.05 \%$ spinel; this composition is listed as 'cumulate' in Table 7. Such olivine-rich gabbros are rare in the oceanic crust. This composition is more likely represented by a mixture of ultramafic (olivine \pm clinopyroxene) and troctolites (plagioclase + clinopyroxene \pm olivine), which are common in the lower oceanic crust.

The bulk oceanic crust composition should be intermediate between the average MORB composition, presumably representative of layer 2 (the volcanic and dike layer) and layer 3 (the gabbroic layer). This is the case for most oxides in the estimated bulk oceanic crust composition in Table 7, with two exceptions: $\mathrm{MgO}$ and $\mathrm{Na}_{2} \mathrm{O}$. The estimated bulk crustal composition is richer in $\mathrm{MgO}$ and poorer in $\mathrm{Na}_{2} \mathrm{O}$ than either the mean or median of lower crustal gabbros listed in Table 2 of Coogan (see Chapter 4.14) (although it falls within one standard deviation of the latter). This suggests that the bulk ocean crust composition listed in Table 7 may be slightly too mafic. On the other hand, Coogan (see Chapter 4.14) concludes that the average $\mathrm{Mg}$ number of the gabbro suites sampled to date is too low to represent the bulk composition of the lower oceanic crust. This would be the case if magmas experience some fractional crystallization in the mantle before rising into the crust. The average MORB glass composition listed in Table 1 has significantly more $\mathrm{Na}_{2} \mathrm{O}$ (and $\mathrm{TiO}_{2}$ ) than the average MORB whole rock, despite having rather similar concentrations of most major oxides. Thus, it is possible that, by using the glass rather than the whole-rock MORB composition, the bulk crust $\mathrm{Na}_{2} \mathrm{O}$ has been overestimated.

Trace elements $\mathrm{Cr}, \mathrm{Ni}$, and Co were estimated using the MELTS simulations. The remaining trace elements in the parental magma were estimated using the equation for trace element distribution during fractional crystallization:

$$
\frac{C_{i}^{\mathrm{l}}}{C_{i}^{\mathrm{o}}}=(1-X)^{D-1}
$$

where $C^{\mathrm{l}}$ is the liquid composition, $C^{\mathrm{o}}$ is the parental magma composition, $X$ is the fraction of liquid remaining, and $D$ is the bulk partition coefficient. Partition coefficients used in the calculation are listed in Table 8 and were selected from the GERM partition coefficient database (http://earthref.org/ GERM/) based on temperature, pressure, composition, and self-consistency. Calculated trace element concentrations of the bulk crust fall, as they should, between the MORB average concentrations in Table 2 and the lower crustal gabbro average or median concentrations listed in Table 2 of Coogan (see Chapter 4.14), with the exception of $\mathrm{Cu}$, for which the bulk crustal estimate appears too low, and $\mathrm{Zn}$, for which the bulk crustal estimate appears too high. The explanation in the case of copper may be the small amounts of a sulfide phase that has fractionated; in the case of $\mathrm{Zn}$, the problem most likely lies in the partition coefficients used.

Figure 23 illustrates MORB, N-MORB, and bulk oceanic crust trace element compositions from Tables 2 and 8, along with previous estimates of MORB composition in a 'spider' or 'extended rare earth' plot in which concentrations are normalized to the estimated bulk silicate Earth composition of Lyubetskaya and Korenaga (2007). All show some degree of increasing depletion with increasing incompatibility. It should be pointed out that Lyubetskaya and Korenaga's (2007) estimate of bulk silicate Earth composition, like the earlier ones such as that of McDonough and Sun (1995), is based partly on the assumption of chondritic relative abundances of refractory lithophile elements. However, the nonchondritic ${ }^{142} \mathrm{Nd} /{ }^{144} \mathrm{Nd}$ ratios of all modern terrestrial material (Boyet and Carlson, 2005) make this assumption questionable and raise the possibility that the Earth is depleted in highly incompatible elements relative to chondrites (Caro and Bourdon, 2010; O'Neill and Palme, 2008). If so, MORB and the oceanic crust may be less incompatible element-depleted relative to the bulk silicate Earth than this figure suggests.

All estimates of MORB composition exhibit strong negative $\mathrm{Pb}$ anomalies and, to varying extents, negative $\mathrm{Sr}$ anomalies. As was noted in an earlier section, average MORB also appears to have a small negative $\mathrm{Eu}$ anomaly. The $\mathrm{Pb}$ anomaly is also present in the bulk crust estimate, but is less pronounced. This reflects the compatibility of $\mathrm{Pb}$ in plagioclase and, consequently, its relatively high bulk partition coefficient during fractional crystallization within the oceanic crust. Thus, the negative $\mathrm{Pb}$ anomaly in MORB is due, in part, to plagioclase fractionation. Sulfide fractionation/segregation, which we have not considered, may also contribute to development of the negative $\mathrm{Pb}$ anomaly.

In contrast to the negative $\mathrm{Sr}$ and $\mathrm{Eu}$ anomalies seen in MORB, the 'bulk oceanic crust' appears to have positive $\mathrm{Sr}$ and $\mathrm{Eu}$ anomalies of 28 and $11 \%$, respectively, which are somewhat smaller than those deduced by Niu and O'Hara (2009). Thus, both the negative $\mathrm{Sr}$ and Eu anomalies in average MORB appear to be due to plagioclase fractionation. The question of whether the $\mathrm{Sr}$ and Eu excesses (as well as Ta and $\mathrm{Nb}$ excesses) in MORB and its mantle source balance the observed deficits in average continental crust (see Chapter 4.1), as argued by Niu and O'Hara (2009), is beyond the scope of this chapter.

The estimated bulk oceanic crust composition presented here is dependent on various assumptions and hence has significant uncertainties associated with it. These assumptions are undoubtedly too simplistic. For example, magma evolution is polybaric and undoubtedly involves reactions between 
Calculated trace element composition of the bulk oceanic crust

\begin{tabular}{|c|c|c|c|c|c|c|c|c|c|}
\hline & \multirow[t]{2}{*}{ Bulk crust (ppm) } & \multirow[t]{2}{*}{ Ave. MORB ${ }^{\mathrm{a}}$} & \multicolumn{7}{|c|}{ Lower Crust $^{b}$} \\
\hline & & & Mean & $\sigma$ & Median & $\mathrm{D}_{O I}$ & $\mathrm{D}_{C p x}$ & $\mathrm{D}_{\text {plag }}$ & Bulk $\mathrm{D}^{\mathrm{c}}$ \\
\hline $\mathrm{Li}$ & 3.52 & 6.63 & & & & 0.35 & 0.25 & 0.3 & 0.283 \\
\hline $\mathrm{Be}$ & 0.31 & 0.64 & & & & 0.03 & 0.05 & 0.37 & 0.178 \\
\hline B & 0.80 & 1.80 & & & & 0.1 & 0.036 & 0.13 & 0.083 \\
\hline K & 651 & 1237 & & & & & & & \\
\hline $\mathrm{Sc}$ & 36.2 & 37 & 37 & \pm 12 & 40 & 0.3 & 2 & 0.08 & 0.983 \\
\hline V & 177 & 299 & 209 & \pm 136 & 162 & 0.08 & 0.78 & 0.1 & 0.407 \\
\hline $\mathrm{Cr}$ & 317 & 331 & 308 & \pm 129 & 285 & & & & \\
\hline Co & 31.7 & 44 & 50 & \pm 26 & 41 & & & & \\
\hline $\mathrm{Ni}$ & 134 & 100 & 138 & \pm 45 & 159 & & & & \\
\hline $\mathrm{Cu}$ & 43.7 & 80.8 & 71 & \pm 19 & 65 & 0.55 & 0.36 & 0.17 & 0.307 \\
\hline $\mathrm{Zn}$ & 48.5 & 86.8 & 38 & \pm 9.6 & 39 & 0.8 & 0.4 & 0.13 & 0.342 \\
\hline $\mathrm{Rb}$ & 1.74 & 4.05 & & & & 0.0004 & 0.01 & 0.1 & 0.046 \\
\hline $\mathrm{Sr}$ & 103 & 138 & 115 & \pm 30 & 97 & 0.0001 & 0.13 & 1.5 & 0.674 \\
\hline$Y$ & 18.1 & 32.4 & 13.9 & \pm 7.4 & 13 & 0.005 & 0.75 & 0.008 & 0.345 \\
\hline $\mathrm{Zr}$ & 44.5 & 103 & 28.4 & \pm 13.6 & 28 & 0.001 & 0.12 & 0.003 & 0.056 \\
\hline $\mathrm{Nb}$ & 2.77 & 6.44 & 0.93 & \pm 0.65 & 1 & 0.00001 & 0.01 & 0.1 & 0.046 \\
\hline Cs & 0.02 & 0.05 & & & & 0.0002 & 0.006 & 0.1 & 0.044 \\
\hline $\mathrm{Ba}$ & 19.4 & 43.4 & & & & 0.000001 & 0.0005 & 0.25 & 0.103 \\
\hline $\mathrm{La}$ & 2.13 & 4.87 & 0.86 & \pm 0.68 & 0.83 & 0.000001 & 0.07 & 0.08 & 0.065 \\
\hline $\mathrm{Ce}$ & 5.81 & 13.1 & 2.75 & \pm 1.95 & 2.76 & 0.000005 & 0.12 & 0.06 & 0.079 \\
\hline $\operatorname{Pr}$ & 0.94 & 2.08 & 0.52 & \pm 0.38 & 0.53 & 0.00001 & 0.18 & 0.05 & 0.102 \\
\hline $\mathrm{Nd}$ & 4.90 & 10.4 & 2.78 & \pm 1.86 & 2.61 & 0.00005 & 0.28 & 0.05 & 0.148 \\
\hline Sm & 1.70 & 3.37 & 1.1 & \pm 0.68 & 1.09 & 0.0001 & 0.45 & 0.05 & 0.225 \\
\hline $\mathrm{Eu}$ & 0.62 & 1.20 & 0.58 & \pm 0.25 & 0.58 & 0.0005 & 0.45 & 0.50 & 0.250 \\
\hline $\mathrm{Gd}$ & 2.25 & 4.42 & 1.6 & \pm 0.93 & 1.6 & 0.001 & 0.49 & 0.04 & 0.240 \\
\hline $\mathrm{Tb}$ & 0.43 & 0.81 & 0.31 & \pm 0.18 & 0.3 & 0.005 & 0.56 & 0.04 & 0.272 \\
\hline Dy & 2.84 & 5.28 & 2.09 & \pm 1.17 & 2.06 & 0.01 & 0.62 & 0.04 & 0.300 \\
\hline $\mathrm{Ho}$ & 0.63 & 1.14 & 0.46 & \pm 0.29 & 0.48 & 0.013 & 0.66 & 0.05 & 0.323 \\
\hline $\mathrm{Er}$ & 1.85 & 3.30 & 1.34 & \pm 0.77 & 1.32 & 0.015 & 0.72 & 0.05 & 0.350 \\
\hline $\mathrm{Tm}$ & 0.28 & 0.49 & & & & 0.018 & 0.76 & 0.06 & 0.373 \\
\hline $\mathrm{Yb}$ & 1.85 & 3.17 & 1.27 & \pm 0.74 & 1.23 & 0.02 & 0.8 & 0.06 & 0.391 \\
\hline Lu & 0.28 & 0.48 & 0.19 & \pm 0.11 & 0.18 & 0.03 & 0.8 & 0.06 & 0.393 \\
\hline $\mathrm{Hf}$ & 1.21 & 2.62 & & & & 0.01 & 0.24 & 0.03 & 0.123 \\
\hline $\mathrm{Ta}$ & 0.18 & 0.417 & & & & 0.00001 & 0.01 & 0.17 & 0.074 \\
\hline $\mathrm{Pb}$ & 0.47 & 0.657 & & & & 0.0001 & 0.001 & 1.5 & 0.615 \\
\hline Th & 0.21 & 0.491 & & & & 0.00001 & 0.0013 & 0.13 & 0.054 \\
\hline U & 0.07 & 0.157 & & & & 0.00001 & 0.0001 & 0.1 & 0.041 \\
\hline
\end{tabular}

${ }^{a}$ From Table 1.

${ }^{b}$ From Chapter 15, Table 2

${ }^{C}$ Elements for which no partition coefficient is shown were calculated within MELTS.

magma and preexisting crust (e.g., Lissenberg and Dick, 2008) rather than just crystallization. Nevertheless, this exercise demonstrates an important point: that the bulk oceanic crust must be significantly more mafic and significantly poorer in incompatible trace elements than is average MORB. Other approaches (e.g., Karson and Elthon, 1987; Perfit et al., 1996) suggest that the bulk oceanic crust is even more mafic and more incompatible element-depleted than the composition listed in Tables 7 and 8.

\subsubsection{The Composition of Back-Arc Basin Crust}

Behind a number of intraoceanic subduction zones, basins have opened through a rifting and spreading process, much like that at the principal mid-ocean ridges. These 'back-arc basins' are floored by oceanic crust whose structure and composition largely resemble those of the oceanic crust created elsewhere. Back-arc basins and their associated spreading centers do differ from other ocean basins in a few respects: spreading is often highly asymmetric, the lithosphere may behave nonrigidly, and spreading is often episodic, rather than steady state. The back-arc basin spreading centers for which data exists in PetDB are shown in Figure 1.

A statistical summary of these data is presented in Table 9, as well as averages for three specific back-arc spreading centers that help to illustrate the range of compositions that occur. Back-arc basin basalts (BABB) are similar to MORB in many ways, but also exhibit some significant differences (Hawkins and Melchior, 1985; Sinton and Fryer, 1987; Tarney et al., 1977, 1981). Comparison of averages in Tables 1 and 9 shows that $\mathrm{BABB}$ have, on average, somewhat higher $\mathrm{SiO}_{2}$, $\mathrm{Al}_{2} \mathrm{O}_{3}$, and $\mathrm{Na}_{2} \mathrm{O}$ and poorer $\mathrm{FeO}, \mathrm{MgO}$, and $\mathrm{CaO}$ than 


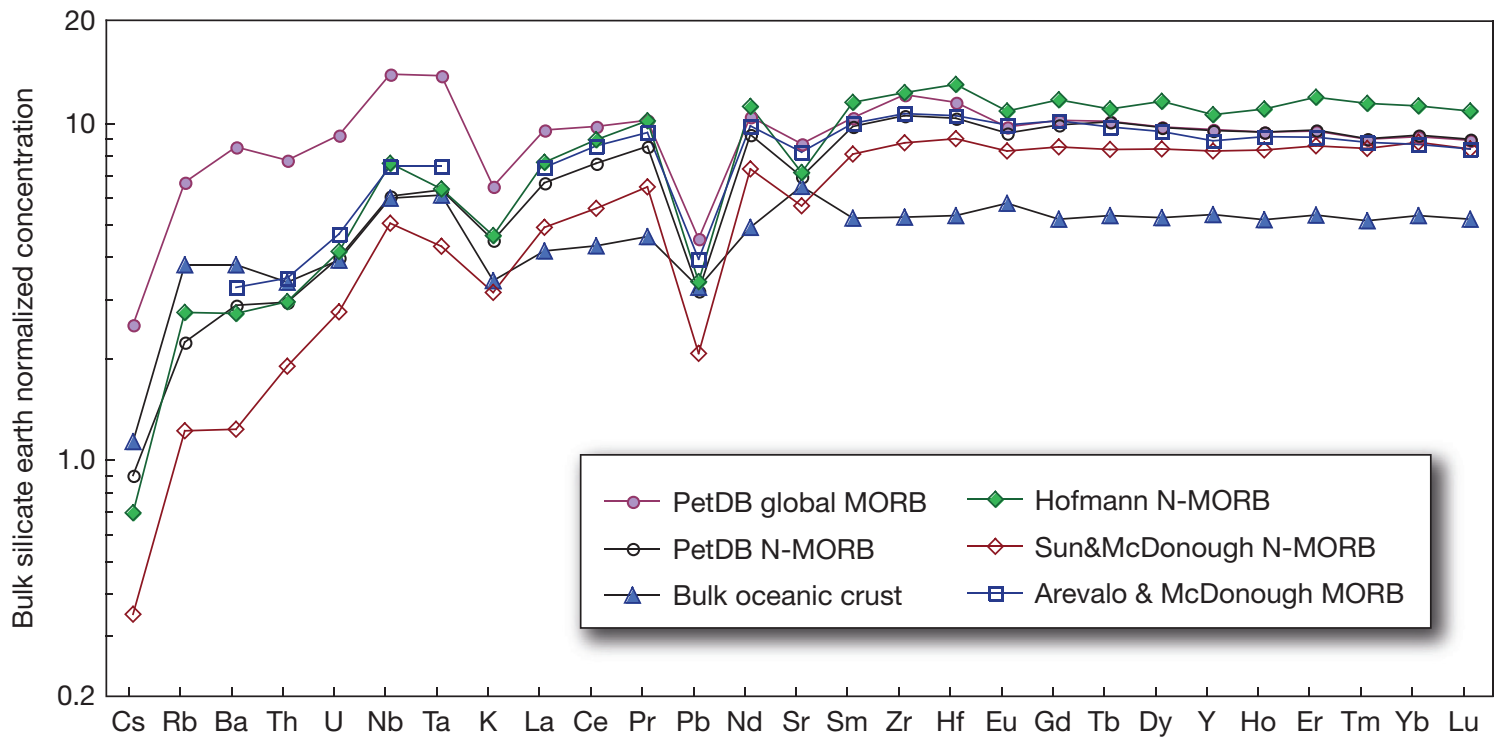

Figure 23 Comparison of the estimated bulk ocean crust composition with various average MORB compositions from Table 2 on a 'Spider' or 'extended rare earth' diagram in which the elements are arranged in order of increasing compatibility. Element concentrations are normalized to the bulk silicate Earth composition estimate of Lyubetskaya and Korenaga (2007). Bulk oceanic crust has a much smaller negative Pb anomaly than average MORB and has positive $\mathrm{Sr}$ and Eu anomalies rather than the negative ones seen in average MORB. Thus, the negative $\mathrm{Pb}, \mathrm{Eu}$, and $\mathrm{Sr}$ anomalies in MORB are due partly $(\mathrm{Pb})$ or wholly $(\mathrm{Sr}, \mathrm{Eu})$ to plagioclase fractionation. Bulk oceanic crust also has a positive $\mathrm{Ta}-\mathrm{Nb}$ anomaly.

Table 9 Major element chemistry of back-arc basin basalts

\begin{tabular}{|c|c|c|c|c|c|c|c|c|c|c|c|c|}
\hline & \multicolumn{3}{|c|}{ Global average } & \multicolumn{3}{|c|}{ Lau Basin } & \multicolumn{3}{|c|}{ Okinawa Trough } & \multicolumn{3}{|c|}{ North Fiji Basin } \\
\hline & Mean & Median & $\sigma$ & Mean & Median & $\sigma$ & Mean & Median & $\sigma$ & Mean & Median & $\sigma$ \\
\hline $\mathrm{SiO}_{2}$ & 52.02 & 50.96 & 4.19 & 51.83 & 51.20 & 2.71 & 56.44 & 51.81 & 8.97 & 49.76 & 49.80 & 0.86 \\
\hline $\mathrm{TiO}_{2}$ & 1.29 & 1.22 & 0.58 & 1.33 & 1.19 & 0.90 & 0.82 & 0.95 & 0.30 & 1.65 & 1.58 & 0.30 \\
\hline $\mathrm{Al}_{2} \mathrm{O}_{3}$ & 15.64 & 15.79 & 1.32 & 14.80 & 14.83 & 1.24 & 15.44 & 15.89 & 1.39 & 15.10 & 14.93 & 0.93 \\
\hline $\mathrm{FeO}_{\mathrm{T}}$ & 9.34 & 9.25 & 2.25 & 10.79 & 10.51 & 2.55 & 7.44 & 8.87 & 3.11 & 10.08 & 10.06 & 1.21 \\
\hline $\mathrm{MnO}$ & 0.18 & 0.18 & 0.04 & 0.19 & 0.19 & 0.03 & 0.15 & 0.16 & 0.06 & 0.17 & 0.18 & 0.03 \\
\hline $\mathrm{MgO}$ & 6.50 & 6.95 & 2.04 & 6.62 & 7.03 & 2.12 & 5.11 & 6.33 & 2.92 & 7.62 & 7.77 & 0.99 \\
\hline $\mathrm{CaO}$ & 10.65 & 11.25 & 2.25 & 10.86 & 11.50 & 2.10 & 8.81 & 11.46 & 4.09 & 11.55 & 11.68 & 0.76 \\
\hline $\mathrm{Na}_{2} \mathrm{O}$ & 2.84 & 2.73 & 0.75 & 2.54 & 2.55 & 0.66 & 2.98 & 2.52 & 0.99 & 2.68 & 2.65 & 0.26 \\
\hline $\mathrm{K}_{2} \mathrm{O}$ & 0.39 & 0.28 & 0.44 & 0.21 & 0.15 & 0.18 & 1.06 & 0.51 & 0.99 & 0.24 & 0.13 & 0.24 \\
\hline $\mathrm{P}_{2} \mathrm{O}_{5}$ & 0.16 & 0.15 & 0.09 & 0.14 & 0.11 & 0.10 & 0.14 & 0.16 & 0.06 & 0.16 & 0.14 & 0.08 \\
\hline $\mathrm{H}_{2} \mathrm{O}$ & 1.00 & 1.02 & 0.61 & 0.70 & 0.59 & 0.48 & - & - & - & 0.81 & 0.74 & 0.54 \\
\hline Total & 100.00 & 99.78 & & 100.01 & 99.84 & & 98.40 & 98.65 & & 99.82 & 99.65 & \\
\hline $\mathrm{Mg \#}$ & 0.58 & & & 0.55 & & & 0.58 & & & 0.60 & & \\
\hline Number & 966 & & & 253 & & & 22 & & & 185 & & \\
\hline
\end{tabular}

MORB. The biggest distinctions are, however, the lower $\mathrm{TiO}_{2}$ and higher $\mathrm{K}_{2} \mathrm{O}$ and $\mathrm{H}_{2} \mathrm{O}$ of $\mathrm{BABB}$. Some of these differences, notably the higher average $\mathrm{SiO}_{2}$ and $\mathrm{Na}_{2} \mathrm{O}$ and lower $\mathrm{MgO}$, appear to be related to the somewhat greater average extent of fractional crystallization. Thus, while average $\mathrm{Na}_{2} \mathrm{O}$ is lower in $\mathrm{BABB}$ than MORB, there is essentially complete overlap at a given $\mathrm{MgO}$ value (Figure 24). On the other hand, the lower $\mathrm{FeO}$ and $\mathrm{TiO}_{2}$ values appear to be more intrinsic, with $\mathrm{BABB}$ generally having lower $\mathrm{FeO}$ and $\mathrm{TiO}_{2}$ than $\mathrm{MORB}$ at a given $\mathrm{MgO}$ value, although there is considerable scatter and overlap in both datasets. Comparison of trends of $\mathrm{Al}_{2} \mathrm{O}_{3}$ versus $\mathrm{MgO}$ of the two datasets is particularly interesting. At the highest $\mathrm{MgO}, \mathrm{BABB}$ have systematically lower $\mathrm{Al}_{2} \mathrm{O}_{3}$, but, while many or most $\mathrm{BABB}$ follow the
MORB trend of decreasing $\mathrm{Al}_{2} \mathrm{O}_{3}$ below 8 wt\% $\mathrm{MgO}$, many $\mathrm{BABB}$ plot well above this trend, so that the more fractionated $\mathrm{BABB}$, those with less than $6 \mathrm{wt} \% \mathrm{MgO}$, have systematically higher $\mathrm{Al}_{2} \mathrm{O}_{3}$. This effect may reflect the suppression of plagioclase crystallization by the higher $\mathrm{H}_{2} \mathrm{O}$ content of BABB (e.g., Plank and Langmuir, 1988).

As has often been pointed out (e.g., Fryer et al., 1990; Hawkins and Melchior, 1985), BABB bear some similarity to lavas from island arcs, most likely because they, like arc magmas, contain a component derived (albeit indirectly) from subducting lithosphere. There is, however, considerable variation between back-arc spreading centers, as well as along individual spreading centers (Sinton et al., 2003; Vallier et al., 1991). Basalts from the North Fiji Basin have lower mean $\mathrm{SiO}_{2}$ 

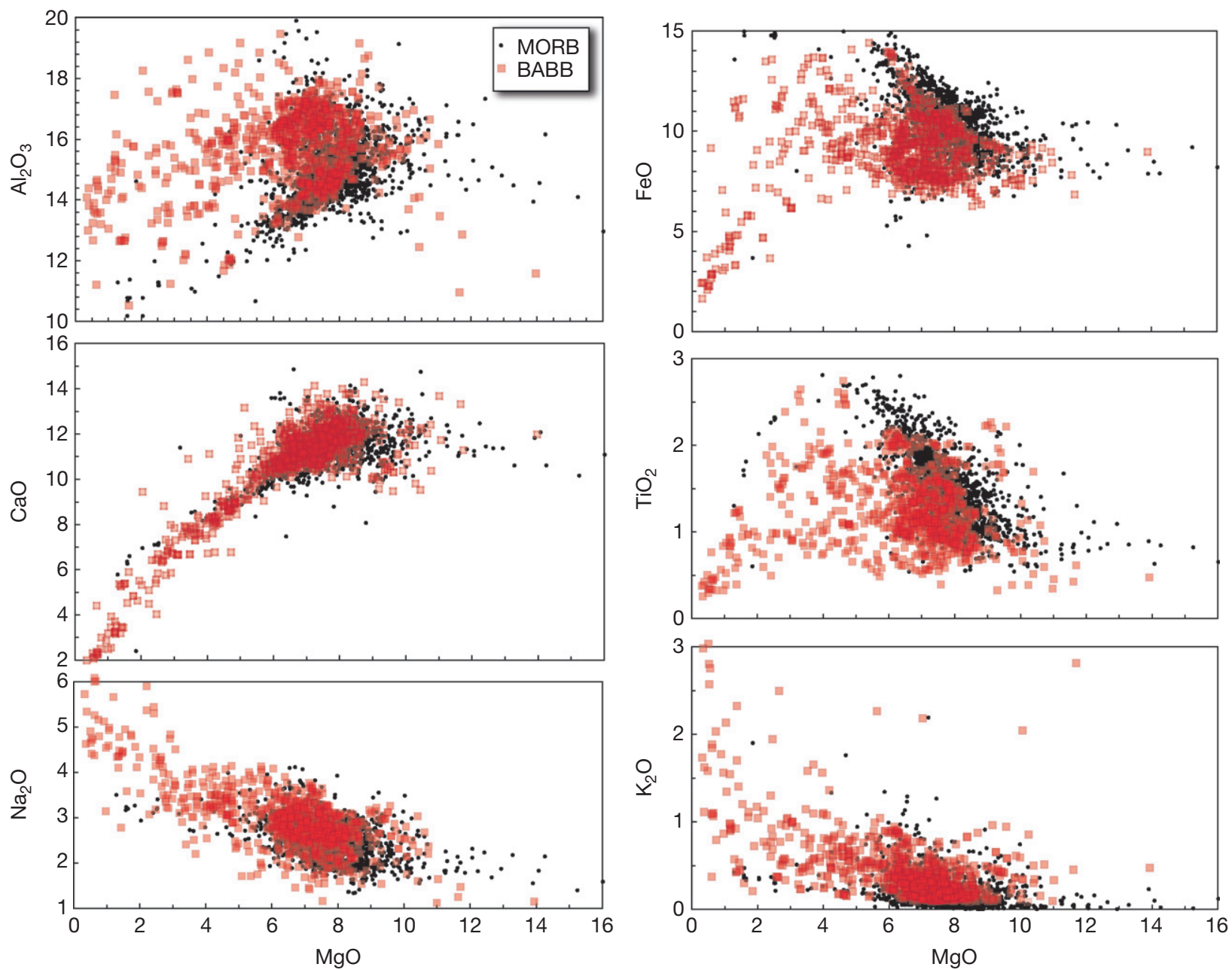

Figure 24 Comparison of major element variations in $\mathrm{MORB}$ and $\mathrm{BABB}$. $\mathrm{BABB}$ generally having lower $\mathrm{FeO}$ and $\mathrm{TiO}_{2}$ than $\mathrm{MORB}$ at a given $\mathrm{MgO}$ value. There is also some tendency for greater $\mathrm{Al}_{2} \mathrm{O}_{3}$ enrichment among differentiated $\mathrm{BABB}$, but compositions are otherwise similar to MORB. Data from PetDB.

and higher $\mathrm{TiO}_{2}$ than average $\mathrm{MORB}$ and $\mathrm{Al}_{2} \mathrm{O}_{3}, \mathrm{FeO}, \mathrm{MgO}$, and $\mathrm{CaO}$ nearly identical to average $\mathrm{MORB}$, although with higher $\mathrm{H}_{2} \mathrm{O}$. Lavas from the Okinawa Trough show the greatest average deviation from MORB.

A number of workers have noted a relationship between the age of rifting, distance from the island arc, and lava chemistry (e.g., Gill, 1976; Sinton et al., 2003; Tarney et al., 1977). Because back-arc rifting often initiates near or within the island arc itself and migrates away through asymmetric spreading, age of rifting and distance from the arc are often related. In general, young rifts close to the arc erupt lavas with more arc-like chemistry, whereas mature back-arc spreading centers erupt lavas closest in composition to MORB (e.g., Gill, 1976; Tarney et al., 1977). This suggests that the 'slab-derived component' may become progressively diluted over time (Sinton et al., 2003). This relationship is, however, not uniformly observed. For example, the lavas from the Sumisu and Torishima rifts in the Izu Bonin arc display a wide range of compositions, although these rifts are quite young and located virtually within the arc itself (Fryer et al., 1990). Here, the variation appears to be primarily geographic rather than temporal.
Table 10 and Figure 25 compare the trace element composition of BABB and MORB and illustrate both the similarities and differences between them. Average trace element ratios in $\mathrm{BABB}$ are listed in Table 4. For the rare earths, BABB and MORB are remarkably similar, although $\mathrm{BABB}$ are, on average, slightly more LREE-enriched than average MORB $\left(\mathrm{La} / \mathrm{Sm}_{\mathrm{N}}\right.$ of $1.13 \mathrm{vs}$. 0.90). BABB have similar $Y$ concentrations and are slightly poorer in $\mathrm{Zr}$ and $\mathrm{Hf}$ than MORB. On a spider diagram, such as Figure 25, both MORB and N-MORB display negative $\mathrm{Pb}$ and $\mathrm{Sr}$ anomalies, whereas BABB display positive ones. MORB and $\mathrm{BABB}$ diverge in composition for elements more incompatible than La. Most of these highly incompatible elements, particularly $\mathrm{Cs}, \mathrm{Rb}, \mathrm{Ba}$, and $\mathrm{K}$, are present in higher concentrations in average BABB than in average MORB, but average $\mathrm{BABB}$ has lower $\mathrm{Ta}$ and $\mathrm{Nb}$ concentrations than average MORB. In terms of trace element ratios, BABB have notably higher $\mathrm{K} / \mathrm{La}, \mathrm{Ba} / \mathrm{La}$, and $\mathrm{Pb} / \mathrm{Ce}$ and lower $\mathrm{K} / \mathrm{Rb}, \mathrm{Nb} / \mathrm{La}$, and $\mathrm{Nb} / \mathrm{U}$ than MORB. Elevated concentrations of the alkalis, alkaline earths, and $\mathrm{Pb}$ and low concentrations of $\mathrm{Nb}$ and $\mathrm{Ta}$ are characteristic of island-arc lavas; hence the average composition of $\mathrm{BABB}$ does indeed differ from average MORB in that it 
Table 10 Average trace element concentrations in back-arc basin basalts

\begin{tabular}{|c|c|c|c|c|c|c|c|c|}
\hline & BABB mean & $\sigma$ & $\mathrm{n}$ & Lau Basin & Okinawa Trough & North Fiji Basin & MORB mean & N-MORB mean \\
\hline $\mathrm{Li}$ & 6.99 & 5.08 & 122 & 8.15 & - & - & 6.63 & 6.64 \\
\hline $\mathrm{Be}$ & 0.62 & 0.31 & 14 & 0.85 & - & - & 0.64 & 0.50 \\
\hline B & 4.56 & 3.01 & 25 & 4.25 & - & - & 1.80 & 1.53 \\
\hline K & 3273 & 3687 & 989 & 1794 & 8807 & 1981 & 1237 & 857 \\
\hline Sc & 36.4 & 7.7 & 352 & 38.1 & 36.8 & 36.3 & 36.8 & 38.3 \\
\hline V & 282 & 98 & 583 & 332 & 176 & 285 & 299 & 314 \\
\hline $\mathrm{Cr}$ & 183 & 141 & 554 & 186 & 174 & 254 & 331 & 334 \\
\hline Co & 45.9 & 40.4 & 362 & 40.5 & 37.5 & 42.9 & 43.7 & 43.9 \\
\hline $\mathrm{Ni}$ & 82.8 & 75.8 & 580 & 86.2 & 65.1 & 107 & 100 & 104 \\
\hline $\mathrm{Cu}$ & 78.9 & 34.7 & 437 & 94.4 & - & 81.7 & 80.8 & 82.0 \\
\hline $\mathrm{Zn}$ & 86.5 & 25.8 & 376 & 94.9 & - & 88.2 & 86.8 & 88.0 \\
\hline $\mathrm{Rb}$ & 7.51 & 9.54 & 555 & 4.96 & 61.5 & 4.02 & 4.05 & 1.36 \\
\hline $\mathrm{Sr}$ & 189 & 96 & 753 & 130 & 208 & 139 & 138 & 110 \\
\hline Y & 28.3 & 11.0 & 517 & 30.9 & 23.6 & 32.6 & 32.4 & 32.2 \\
\hline $\mathrm{Zr}$ & 89.7 & 44.2 & 502 & 69.9 & 125 & 101 & 103 & 88.8 \\
\hline $\mathrm{Nb}$ & 3.76 & 4.40 & 426 & 1.65 & 4.93 & 5.88 & 6.44 & 2.8 \\
\hline Cs & 0.19 & 0.19 & 188 & 0.15 & 0.41 & 0.12 & 0.053 & 0.019 \\
\hline $\mathrm{Ba}$ & 78.4 & 85.3 & 647 & 54.9 & 213 & 42.7 & 43.4 & 14.7 \\
\hline $\mathrm{La}$ & 5.79 & 4.46 & 427 & 3.39 & 7.04 & 5.70 & 4.87 & 3.39 \\
\hline $\mathrm{Ce}$ & 14.3 & 9.46 & 433 & 9.81 & 16.8 & 15.9 & 13.1 & 10.2 \\
\hline $\mathrm{Pr}$ & 2.21 & 1.22 & 227 & 1.82 & 2.37 & 2.19 & 2.08 & 1.74 \\
\hline $\mathrm{Nd}$ & 10.7 & 5.04 & 515 & 9.43 & 11.0 & 11.22 & 10.4 & 9.22 \\
\hline $\mathrm{Sm}$ & 3.27 & 1.53 & 497 & 3.18 & 3.04 & 3.37 & 3.37 & 3.19 \\
\hline $\mathrm{Eu}$ & 1.15 & .43 & 369 & 1.13 & 1.10 & 1.15 & 1.20 & 1.15 \\
\hline $\mathrm{Gd}$ & 4.10 & 2.20 & 326 & 4.51 & 3.45 & 4.36 & 4.42 & 4.29 \\
\hline $\mathrm{Tb}$ & 0.74 & 0.44 & 229 & 0.82 & 0.59 & 0.73 & 0.81 & 0.81 \\
\hline Dy & 4.80 & 2.66 & 337 & 5.60 & 3.72 & 5.28 & 5.28 & 5.27 \\
\hline $\mathrm{Ho}$ & 1.05 & 2.66 & 236 & 1.22 & 0.80 & 0.99 & 1.14 & 1.14 \\
\hline $\mathrm{Er}$ & 2.99 & 1.7 & 346 & 3.53 & 2.33 & 3.21 & 3.30 & 3.31 \\
\hline $\mathrm{Tm}$ & 0.47 & 0.32 & 203 & 0.56 & 0.35 & 0.41 & 0.49 & 0.49 \\
\hline $\mathrm{Yb}$ & 2.97 & 1.73 & 370 & 3.52 & 2.20 & 3.07 & 3.17 & 3.20 \\
\hline $\mathrm{Lu}$ & 0.46 & 0.30 & 274 & 0.55 & 0.34 & 0.43 & 0.48 & 0.49 \\
\hline $\mathrm{Hf}$ & 2.27 & 1.75 & 242 & 2.38 & 1.79 & 2.66 & 2.62 & 2.36 \\
\hline $\mathrm{Ta}$ & 0.270 & 0.281 & 190 & 0.11 & 0.25 & 0.46 & 0.417 & 0.191 \\
\hline W & 0.071 & 0.031 & 22 & 0.078 & - & - & 0.043 & 0.026 \\
\hline $\mathrm{Pb}$ & 1.51 & 1.14 & 310 & 1.03 & 2.16 & 1.85 & 0.657 & 0.460 \\
\hline Th & 0.660 & 0.670 & 305 & 0.30 & 0.81 & - & 0.491 & 0.186 \\
\hline U & 0.200 & 0.173 & 271 & 0.12 & 0.19 & - & 0.157 & 0.068 \\
\hline
\end{tabular}

contains a 'slab-derived component,' albeit less than typical island arcs. The slab-derived component, however, cannot explain the low $\mathrm{Ta}$ and $\mathrm{Nb}$ concentrations relative to MORB, which likely requires larger extents of melting in the $\mathrm{BABB}$ than the MORB setting, resulting from slab-derived water (e.g., Pearce and Stern, 2006).

Figure 25 also demonstrates some of the regional diversity in BABB. Although all three regions illustrated share the enrichment in alkalis and alkaline earths and depletion in $\mathrm{Nb}$ and Ta that distinguish BABB from MORB, the extent of this difference varies considerably. The lavas from the Okinawa Trough show particularly strong alkali enrichment; at the other extreme, lavas from the Lau Basin spreading center differ in composition from typical MORB only slightly, although they still exhibit a small negative $\mathrm{Ta}-\mathrm{Nb}$ anomaly and excess of $\mathrm{K}, \mathrm{Rb}$, Cs, and $\mathrm{Ba}$.

Average isotope ratios in BABB are listed in Table 6. BABB have statistically significant higher mean $\delta^{18} \mathrm{O},{ }^{87} \mathrm{Sr} /{ }^{87} \mathrm{Sr}$, and $\mathrm{Pb}$ isotope ratios than MORB and statistically significant lower $\varepsilon_{\mathrm{Nd}}, \delta^{13} \mathrm{C}$, and $\delta \mathrm{D}$ than MORB. As Figure 26 shows, BABB typically have somewhat higher ${ }^{87} \mathrm{Sr} /{ }^{86} \mathrm{Sr}$ for a given $\varepsilon_{\mathrm{Nd}}$. All these isotopic features also typify island-arc lavas in comparison to MORB. Thus, the isotopic data are consistent with the trace element data in suggesting that $\mathrm{BABB}$ contain a dilute slab-derived component.

Interestingly, the BABB $\mathrm{Sr}-\mathrm{Nd}$ isotopic array is also somewhat more confined and extends to neither the very 'enriched' isotopic signatures nor to the extremely 'depleted' isotopic signatures of the MORB array. The lack of enriched isotopic signatures may, in part, reflect the complete absence of mantle plumes in back-arc basin environments - perhaps due to subducting lithosphere shielding these regions from deep mantle upwellings.

Figure 27 shows that $\mathrm{Pb}$ isotopic compositions of $\mathrm{BABB}$ plot within the MORB field. There is some tendency for $\mathrm{BABB}$ to have slightly higher ${ }^{207} \mathrm{~Pb} /{ }^{204} \mathrm{~Pb}$ and ${ }^{208} \mathrm{~Pb} /{ }^{204} \mathrm{~Pb}$ for a given ${ }^{206} \mathrm{~Pb} /{ }^{204} \mathrm{~Pb}$ compared to typical MORB; in this sense they resemble Indian Ocean MORB more than other MORB. Continental material, which could find its way into a subduction zone either through sediment subduction (see Chapter 4.17) or 


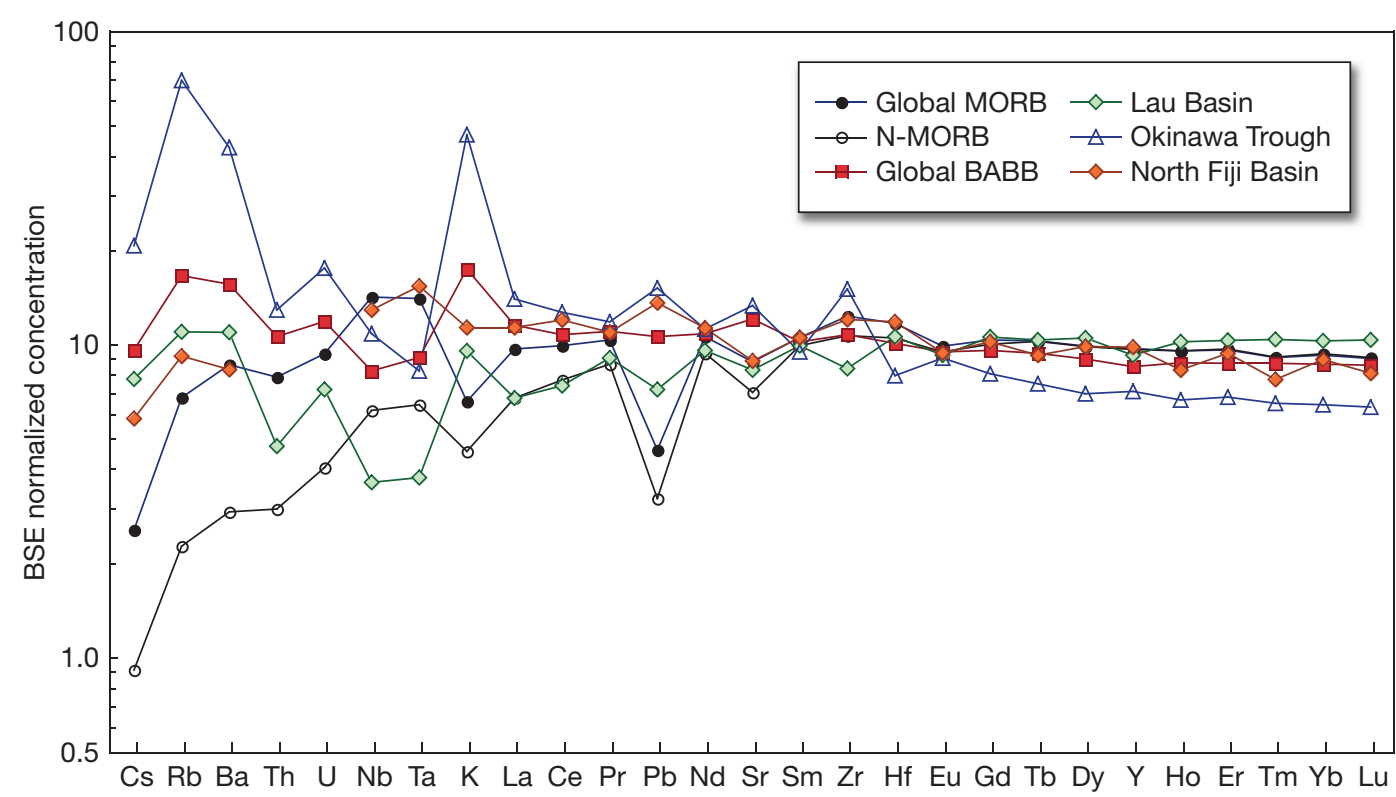

Figure 25 Comparison of incompatible element concentrations in BABB and MORB, normalized to the bulk silicate earth composition of Lyubetskaya and Korenaga (2007). In contrast to MORB, BABB generally show relative depletions in Ta and Nb, slight enrichments in $\mathrm{Pb}$ and $\mathrm{Sr}$, and more pronounced enrichments in $\mathrm{K}, \mathrm{Rb}, \mathrm{Cs}$, and Ba. Comparison of average compositions from the Lau Basin, Okinawa Trough, and North Fiji Basin shows, however, that these effects can vary considerably in BABB.

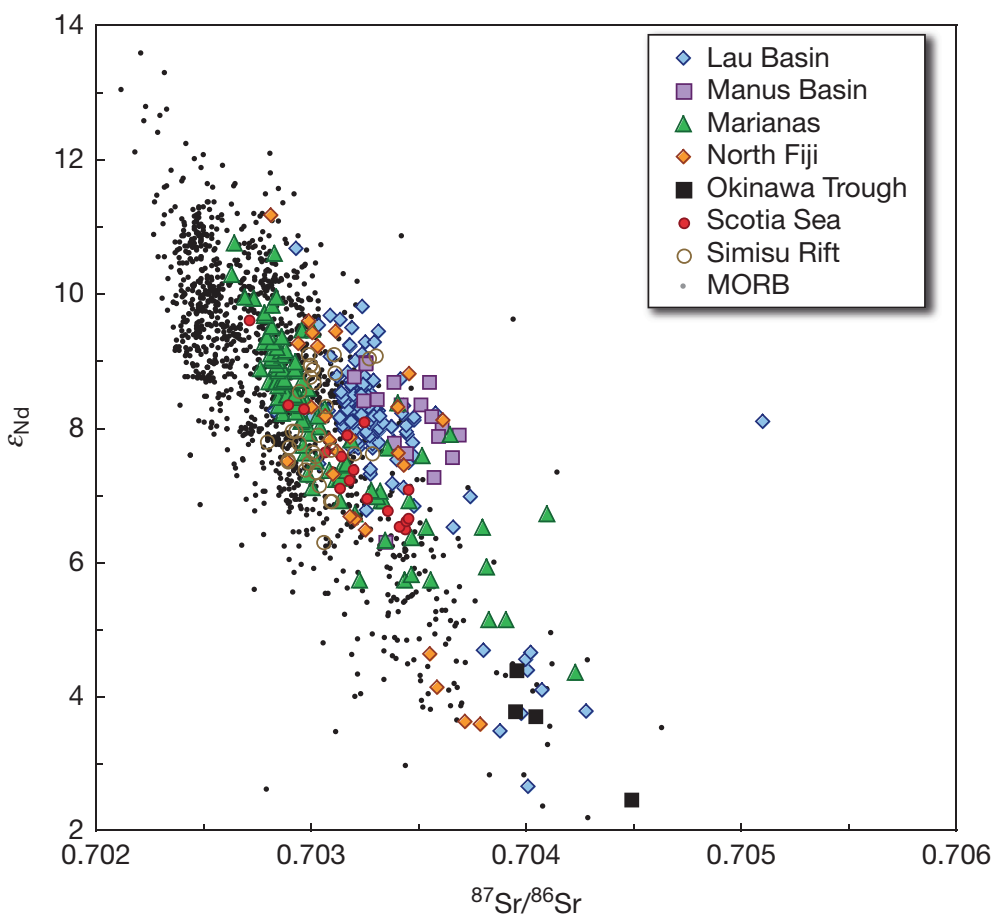

Figure 26 Sr and Nd isotope ratios in BABB. BABB largely overlap the MORB field, but tend to have higher ${ }^{87} \mathrm{Sr} /{ }^{86} \mathrm{Sr}$ for a given $\varepsilon_{\mathrm{Nd}}$. Data from PetDB.

subduction erosion of the overlying plate, typically has higher ${ }^{207} \mathrm{~Pb} /{ }^{204} \mathrm{~Pb}$ and ${ }^{208} \mathrm{~Pb} /{ }^{204} \mathrm{~Pb}$ for a given ${ }^{206} \mathrm{~Pb} /{ }^{204} \mathrm{~Pb}$ than does MORB. Thus, the explanation for the slight differences in $\mathrm{Pb}$ isotopic composition between MORB and BABB is most likely the same as the explanation for the other isotopic differences, namely, a dilute slab-derived component present in BABB.

\subsubsection{Future Directions}

Over the past few decades, countless oceanographic expeditions have probed and sampled the oceanic crust in many ways and in many places. These efforts have produced a reasonably detailed picture of its structure and composition 

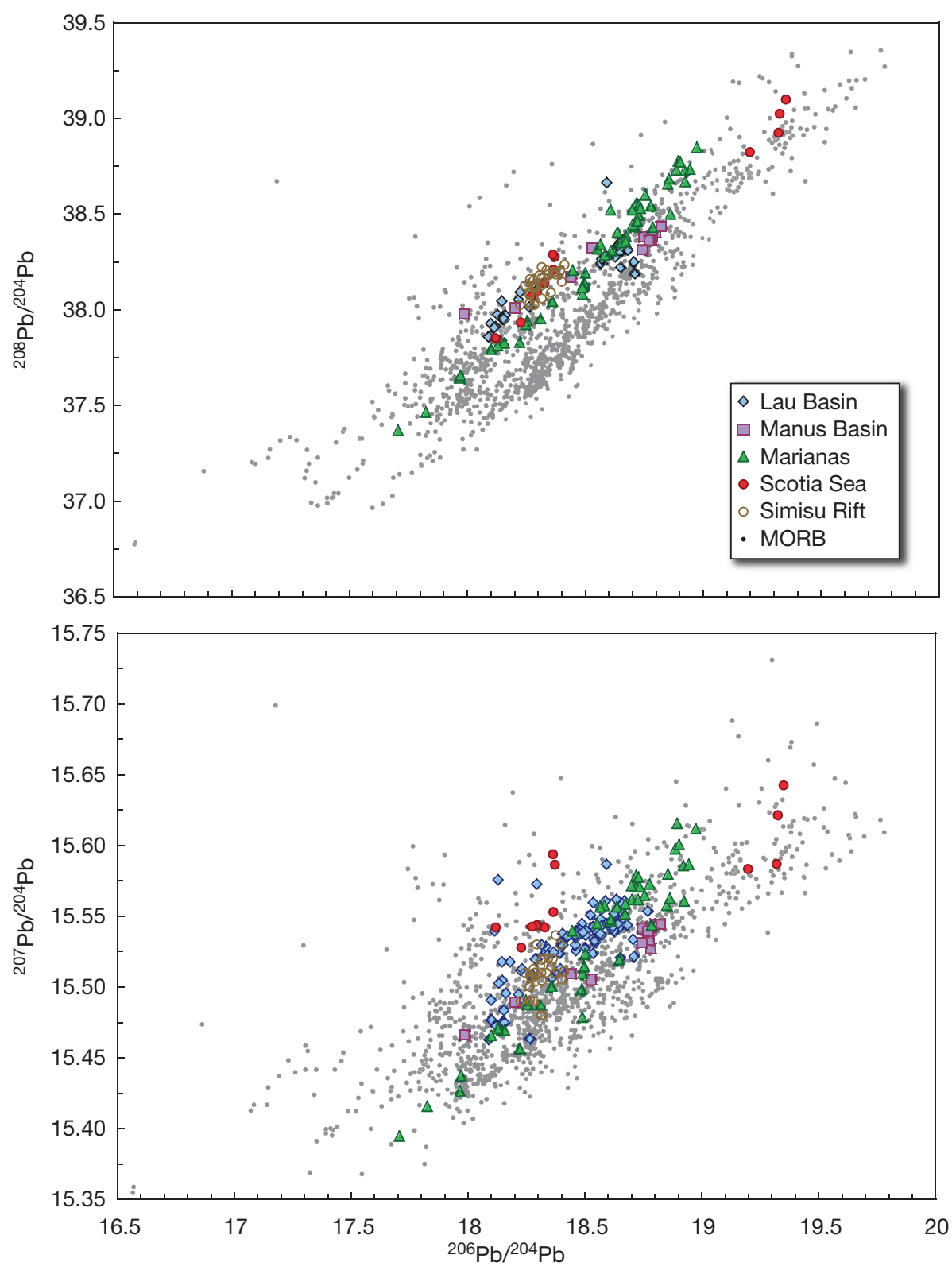

Figure $27 \mathrm{~Pb}$ isotope ratios in $\mathrm{BABB}$. BABB have $\mathrm{Pb}$ isotope ratios that are similar to MORB, although there is a tendency for $\mathrm{BABB}$ to have higher ${ }^{208} \mathrm{~Pb} /{ }^{204} \mathrm{~Pb}$ for a given ${ }^{206} \mathrm{~Pb} /{ }^{204} \mathrm{~Pb}$ and some tendency for BABB to scatter to higher ${ }^{207} \mathrm{~Pb} /{ }^{204} \mathrm{~Pb}$. Data from PetDB.

and have led to firmly established, if evolving, paradigms of how the crust forms and varies with external parameters such as spreading rate, magma supply, mantle temperature. Some areas, such as the NSF RIDGE Integrated Study Sites on the EPR and Juan de Fuca Ridge, have been studied and sampled in great detail. Other regions, such as much of the MAR, have been extensively sampled at the reconnaissance level, with average sampling densities near or above one sample per 10 kilometers of ridge, and occasional more detailed sampling such as at the FAMOUS area at $37^{\circ} \mathrm{N}$. Yet vast areas of the ridge system, such as most of the Chile Ridge, a vast stretch of the Pacific-Antarctic Ridge to its south, and nearly all of the Southeast Indian and Pacific-Antarctic ridges south of $50^{\circ} \mathrm{S}$, have not be sampled or mapped at all. Expeditions to these areas will provide opportunities to test these paradigms.
In addition to exploring new areas of the ridge system, focused study of more accessible areas will provide opportunities to test our ideas in other ways. For example, most chemical and petrological studies to date have focused on the easily accessible and readily sampled extrusive layer; far less is known about the dikes and gabbros. Are the dikes compositionally identical on average to the extrusives or are they more mafic? The relatively small amount of data we have on dikes and gabbros suggest complex relationships to the well-studied lavas above, in some cases challenging inferences made about processes occurring at depth (e.g., Lissenberg and Dick, 2008). Furthermore, much of what we know about the deep crust comes from anomalous regions where it is at or near the surface, such as core complexes and fracture zones. Are inferences made from such areas applicable to more typical areas of the ridge 
system? Only by direct sampling of deep crust through drilling in these more typical areas will we be able to address this question.

We have learned much over the last 20 years about eruption styles and intervals and the magma chambers that feed these eruptions on fast- and intermediate-spreading ridges, but we still know very little about eruptions and magmatic plumbing on slow-spreading ridges. While serendipity may yet provide us with examples of near real-time eruptions on slow-spreading ridges, rapidly evolving dating techniques based on the $U$ and Th decay series isotopes may prove more insightful to understand the eruption frequency and sizes on slow-spreading ridges.

Enormous progress has also been made through theoretical approaches to understand melt generation and evolution over the past 30 years. We now have powerful thermodynamicsbased tools to model these processes. Yet, there is reason to suspect that these processes involve vastly greater complexity than currently envisioned and modeled. For example, we remain unsure of the degree to which MORB is generated by melting of peridotite, from stringers and pods of eclogite and pyroxene embedded in peridotite or from a combination of both; arguments have been advanced for each of these possibilities. The mismatch in the Os isotopic composition of MORB and abyssal peridotites is a particularly nagging problem because it suggests that melt generation may be, at least in part, a disequilibrium process and hence not readily modeled through thermodynamics.

We expect to see great progress on all these fronts over the next decade. Some of questions will have been answered, but new questions will undoubtedly arise. The remains ample opportunity for future generations of scientists to study the oceanic crust.

\section{Acknowledgments}

This review benefited enormously from careful reviews by Mike Perfit and Ken Rubin, as well as editor Roberta Rudnick. The authors also gratefully acknowledge having made extensive use of the PetDB database managed by the Integrated Earth Data Applications Facility at Columbia University.

\section{References}

Alt JC, Kinoshita H, Stokking LB, et al. (1993) Proceedings of the Ocean Drilling Program, Initial Reports, vol. 148. College Station, TX: Ocean Drilling Program.

Arevalo R Jr. and McDonough WF (2010) Chemical variations and regional diversity observed in MORB. Chemical Geology 271: 70-85.

Asimow PD, Dixon JE, and Langmuir CH (2004) A hydrous melting and fractionation model for mid-ocean ridge basalts: Application to the Mid-Atlantic Ridge near the Azores. Geochemistry, Geophysics, Geosystems 5: Q01E16. http://dx.doi.org/ 10.1029/2003GC000568

Asimow PD and Ghiorso MS (1998) Algorithmic modifications extending MELTS to calculate subsolidus phase relations. American Mineralogist 83: 1127-1131.

Asimow PD, Hirschmann MM, and Stolper EM (2001) Calculation of peridotite partial melting from thermodynamic models of minerals and melts, IV. Adiabatic decompression and the composition and mean properties of mid-ocean ridge basalts. Journal of Petrology 42: 963-998.

Asimow PD and Langmuir CH (2003) The importance of water to oceanic mantle melting regimes. Nature 421: 815-820.

Batiza R (1984) Inverse relationship between Sr isotope diversity and rate of oceanic volcanism has implications for mantle heterogeneity. Nature 309: 440-441.
Batiza R and Vanko D (1984) Petrology of young Pacific seamounts. Journal of Geophysical Research 89: 11235-11260.

Behn MD, Conrad CP, and Silver PG (2004) Detection of upper mantle flow associated with the African Superplume. Earth and Planetary Science Letters 224: 259-274.

Bergmanis EC, Sinton J, and Rubin KH (2007) Recent eruptive history and magma reservoir dynamics on the southern East Pacific Rise at $17^{\circ} 30^{\prime} \mathrm{S}$. Geochemistry, Geophysics, Geosystems 8: Q12006. http://dx.doi.org/10.1029/2007gc001742.

Blackman DK, Cann JR, Janssen B, and Smith DK (1998) Origin of extensional core complexes: Evidence from the Mid-Atlantic Ridge at Atlantis Fracture Zone. Journal of Geophysical Research 103(B9): 21315-21333.

Bowen NL (1928) The Evolution of the Igneous Rocks. Princeton: Princeton University Press.

Boyet M and Carlson RW (2005) ${ }^{142} \mathrm{Nd}$ evidence for early (>4.53 Ga) global differentiation of the silicate Earth. Science 309: 576-581.

Brandon AD, Snow JE, Walker RJ, Morgan JW, and Mock TD (2000) ${ }^{190} \mathrm{Pt} /{ }^{186}$ Os and ${ }^{187} \mathrm{Re} /{ }^{187}$ Os systematics of abyssal peridotites. Earth and Planetary Science Letters 177: 319-335

Burton KW, Schiano P, Birck J-L, and Allègre CJ (1999) Osmium isotope disequilibrium between mantle minerals in a spinel-Iherzolite. Earth and Planetary Science Letters 172: 311-322.

Canales JP, Detrick RS, Bazin S, Harding AJ, and Orcutt JA (1998) Off-axis crustal thickness across and along the East Pacific Rise within the MELT area. Science 280: 1218-1221.

Carbotte SM, Detrick RS, Harding A, et al. (2006) Rift topography linked to magmatism at the intermediate spreading Juan de Fuca Ridge. Geology 34: 209-212.

Carbotte SM, Nedimovi RM, Canales JP, Kent GM, Harding AJ, and Marjanovi M (2008) Variable crustal structure along the Juan de Fuca Ridge: Influence of on-axis hot spots and absolute plate motions. Geochemistry, Geophysics, Geosystems 9: Q08001. http://dx.doi.org/10.1029/2007gc001922.

Carbotte SM and Scheirer DS (2004) Variability of ocean crustal structure created along the global midocean ridge. In: Davis EE and Elderfield $\mathrm{H}$ (eds.) Hydrogeology of the Oceanic Lithosphere, pp. 59-107. Cambridge: Cambridge University Press.

Caro G and Bourdon B (2010) Non-chondritic Sm/Nd ratio in the terrestrial planets: Consequences for the geochemical evolution of the mantle crust system. Geochimica et Cosmochimica Acta 74: 3333-3349.

Castillo PR, Klein E, Bender J, et al. (2000) Petrology and Sr, Nd and Pb isotope geochemistry of mid-ocean ridge basalt glasses from the $11^{\circ} 45^{\prime} \mathrm{N}$ to $15^{\circ} 00^{\prime} \mathrm{N}$ segment of the East Pacific Rise. Geochemistry, Geophysics, Geosystems 1: 1011 http://dx.doi.org/10.1029/1999GC000024

Christeson GL, McIntosh KD, and Karson JA (2007) Inconsistent correlation of seismic layer 2a and lava layer thickness in oceanic crust. Nature 445: 418-421.

Cipriani A, Brueckner HK, Bonatti E, and Brunelli D (2004) Oceanic crust generated by elusive parents: $\mathrm{Sr}$ and $\mathrm{Nd}$ isotopes in basalt-peridotite pairs from the Mid-Atlantic Ridge. Geology 32: 657-660.

Cogley JG (1984) Continental margins and the extent and number of the continents. Reviews of Geophysics and Space Physics 22: 101-122.

Cogné J-P, Humler E, and Courtillot V (2006) Mean age of oceanic lithosphere drives eustatic sea-level change since Pangea breakup. Earth and Planetary Science Letters 245: 115-122.

Crawford WC and Webb SC (2002) Variations in the distribution of magma in the lower crust and at the Moho beneath the East Pacific Rise at $9^{\circ}-10^{\circ} \mathrm{N}$. Earth and Planetary Science Letters 203: 117-130.

Danyushevsky LV (2001) The effect of small amounts of $\mathrm{H}_{2} \mathrm{O}$ on crystallisation of mid-ocean ridge and backarc basin magmas. Journal of Volcanology and Geothermal Research 110: 265-280.

Danyushevsky LV and Plechov P (2011) Petrolog3: Integrated software for modeling crystallization processes. Geochemistry, Geophysics, Geosystems 12: Q07021. http://dx.doi.org/10.1029/2011gc003516.

Darbyshire FA, White RS, and Priestley KF (2000) Structure of the crust and uppermost mantle of Iceland from a combined seismic and gravity study. Earth and Planetary Science Letters 181: 409-428.

Davis AS, Claque DA, and White WM (1998) Geochemistry of basalt from Escanaba Trough: Evidence for sediment contamination. Journal of Petrology 39: 841-858.

DeMets C, Gordon RG, and Argus DF (2010) Geologically current plate motions. Geophysical Journal International 181: 1-80.

Detrick RS, Buhl P, Vera E, et al. (1987) Multi-channel seismic imaging of a crustal magma chamber along the East Pacific Rise. Nature 326: 35-41.

Detrick RS, Sinton JM, Ito G, et al. (2002) Correlated geophysical, geochemical, and volcanological manifestations of plume-ridge interaction along the Galapagos Spreading Center. Geochemistry, Geophysics, Geosystems 3: 8501. http://dx.doi. org/10.1029/2002GC000350. 
Dick HJB, Bryan WB, and Thompson G (1981) Low-angle detachment faulting and steady-state emplacement of plutonic rocks at ridge-transform intersections. Eos, Transactions of the American Geophysical Union 62: 406.

Dick HJB, Fisher RL, and Bryan WB (1984) Mineralogic variability of the uppermost mantle along mid-ocean ridges. Earth and Planetary Science Letters 69: 88-106.

Dick HJB, Lin J, and Schouten H (2003) An ultraslow-spreading class of ocean ridge. Nature 426: 405-412.

Dick HJB, Tivey MA, and Tucholke BE (2008) Plutonic foundation of a slow-spreading ridge segment: Oceanic core complex at Kane Megamullion, $23^{\circ} 30^{\prime} \mathrm{N}, 45^{\circ} 20^{\prime} \mathrm{W}$. Geochemistry, Geophysics, Geosystems 9: Q05014. http://dx.doi.org/10.1029/ 2007 gc001645.

Donnelly KE, Goldstein SL, Langmuir CH, and Spiegelman M (2004) Origin of enriched ocean ridge basalts and implications for mantle dynamics. Earth and Planetary Science Letters 226: 347-366

Dupré B and Allègre CJ (1983) Pb-Sr isotope variations in Indian Ocean basalts and mixing phenomena. Nature 303: 142-146.

Dziak RP, Bohnenstiehl DR, Cowen JP, et al. (2007) Rapid dike emplacement leads to eruptions and hydrothermal plume release during seafloor spreading events. Geology 35: 579-582.

Edwards MH, Kurras GJ, Tolstoy M, Bohnenstiehl DR, Coakley BJ, and Cochran JR (2001) Evidence of recent volcanic activity on the ultraslow-spreading Gakkel ridge. Nature 409: 808-812.

Elliott T, Thomas A, Jeffcoate A, and Niu Y (2006) Lithium isotope evidence for subduction-enriched mantle in the source of mid-ocean-ridge basalts. Nature 443: 565-568.

Embley RW and Chadwick WW Jr. (1994) Volcanic and hydrothermal processes associated with a recent phase of seafloor spreading at the northern Cleft segment: Juan de Fuca Ridge. Journal of Geophysical Research 99: 4741-4760.

Embley RW, Chadwick W, Perfit MR, and Baker ET (1991) Geology of the northern Cleft segment, Juan de Fuca Ridge: Recent lava flows, sea-floor spreading, and the formation of megaplumes. Geology 19: 771-775.

Embley RW, Chadwick WW, Perfit MR, Smith MC, and Delaney JR (2000) Recent eruptions on the CoAxial segment of the Juan de Fuca Ridge: Implications for mid-ocean ridge accretion processes. Journal of Geophysical Research 105: 16501-16525.

Engel AEJ, Engel CG, and Havens RG (1965) Chemical characteristics of oceanic basalts and the upper mantle. Geological Society of America Bulletin 76: 719-734.

Escartin J, Smith DK, Cann J, Schouten H, Langmuir CH, and Escrig S (2008) Central role of detachment faults in accretion of slow-spreading oceanic lithosphere. Nature 455(7214): 790-794.

Escrig S, Capmas F, Dupré B, and Allegre CJ (2004) Osmium isotopic constraints on the nature of the DUPAL anomaly from Indian mid-ocean-ridge basalts. Nature 431: 59-63.

Escrig S, Schiano P, Schilling J-G, and Allègre C (2005) Rhenium-osmium isotope systematics in MORB from the Southern Mid-Atlantic Ridge $\left(40^{\circ}-50^{\circ} \mathrm{S}\right)$. Earth and Planetary Science Letters 235: 528-548.

Fisk MR, Schilling JG, and Sigurdsson H (1980) An experimental investigation of Iceland and Reykjanes Ridge tholeiites: I. Phase relations. Contributions to Mineralogy and Petrology 74: 361-374.

Flower MFJ (1980) Thermal and kinematic control on ocean-ridge magma fractionation: Contrasts between Atlantic and Pacific spreading axes. Journal of the Geological Society 138: 695-712.

Fornari DJ, Haymon RM, Perfit MR, Gregg TKP, and Edwards MH (1998) Axial summit trough of the East Pacific Rise $9^{\circ}-10^{\circ} \mathrm{N}$ : Geological characteristics and evolution of the axial zone on fast spreading mid-ocean ridge. Journal of Geophysical Research 103: 9827-9855

Fornari DJ, Perfit MR, Allan JF, et al. (1988) Geochemical and structural studies of the Lamont seamounts: Seamounts as indicators of mantle processes. Earth and Planetary Science Letters 89: 63-83.

Forsyth D (1998) The MELTS Seismic Team: Imaging the deep seismic structure beneath a mid-ocean ridge: The MELT experiment. Science 280: 1215-1218.

Fowler CMR and Keen CE (1979) Oceanic crustal structure: Mid-Atlantic Ridge at 45 degrees N. Geophysical Journal of the Royal Astronomical Society 56: 219-226.

Fox CG, Chadwick WW, and Embley RW (2001) Direct observation of a submarine volcanic eruption from a sea-floor instrument caught in a lava flow. Nature 412: 727-729.

Fox CG and Dziak RP (1998) Hydroacoustic detection of volcanic activity on the Gorda Ridge, February-March 1996. Deep Sea Research Part II: Topical Studies in Oceanography 45: 2513-2530.

Fryer P, Taylor B, Langmuir CH, and Hochstaedter AG (1990) Petrology and geochemistry of lavas from the Sumisu and Torishima backarc rifts. Earth and Planetary Science Letters 100: 161-178.
Galer SJG and O'Nions RK (1985) Residence time of thorium, uranium and lead in the mantle with implications for mantle convection. Nature 316: 778-782.

Ghiorso MS, Hirschmann MM, Reiners PW, and Kress VC (2002) The pMELTS: A revision of MELTS for improved calculation of phase relations and major element partitioning related to partial melting of the mantle to $3 \mathrm{GPa}$. Geochemistry, Geophysics, Geosystems 3(5): 1030. http://dx.doi.org/10.1029/2001GC000217.

Ghiorso MS and Sack R0 (1995) Chemical mass transfer in magmatic processes IV. A revised and internally consistent thermodynamic model for the interpolation and extrapolation of liquid-solid equilibra in magmatic systems at elevated temperatures and pressures. Contributions to Mineralogy and Petrology 119: 197-212.

Gill JB (1976) Composition and age of Lau Basin and Ridge volcanic rocks: Implications for evolution of an interarc basin and remnant arc. Geological Society of America Bulletin 87: 1384-1395.

Goss AR, Perfit MR, Ridley WI, et al. (2010) Geochemistry of lavas from the 2005-2006 eruption at the East Pacific Rise, $9^{\circ} 47-53^{\prime} \mathrm{N}$ : Implications for ridge crest plumbing and decadal changes in magma chamber compositions. Geochemistry, Geophysics, Geosystems 11: Q05T09. http://dx.doi.org/10.1029/2009gc002977.

Graham D, Zindler A, Kurz M, Jenkins W, Batiza R, and Staudigel H (1988) He, Pb, $\mathrm{Sr}$, and $\mathrm{Nd}$ isotope constraints on magma genesis and mantle heterogeneity beneath young Pacific seamounts. Contributions to Mineralogy and Petrology 99: 446-463.

Gregg PM, Behn MD, Lin J, and Grove TL (2009) Melt generation, crystallization, and extraction beneath segmented oceanic transform faults. Journal of Geophysical Research 114: B11102. http://dx.doi.org/10.1029/2008jb006100.

Grevemeyer I, Schramm B, Devey CW, et al. (2002) A multibeam-sonar, magnetic and geochemical flow-line survey at $14^{\circ} 14^{\prime} \mathrm{S}$ on the southern East Pacific Rise Insights into the fourth dimension of ridge crest segmentation. Earth and Planetary Science Letters 199: 359-372.

Grove TL, Kinzler RJ, and Bryan WB (1992) Fractionation of mid-ocean ridge basalt (MORB). In: Morgan JP, Blackman DK, and Sinton JM (eds.) Mantle Flow and Melt Generation at Mid-Ocean Ridges, Geophysical Monograph Series, vol. 71, pp. 281-310. Washington, DC: American Geophysical Union.

Gu YJ, Webb SC, Lerner-Lam A, and Gaherty JB (2005) Upper mantle structure beneath the eastern Pacific Ocean ridges. Journal of Geophysical Research 110: B06305.

Harding AJ, Kappus ME, Orcutt JA, et al. (1989) The structure of young oceanic crust at $1388^{\circ} \mathrm{N}$ on the East Pacific Rise from ESPS. Journal of Geophysical Research 94: 12163-12196.

Hart SR (1984) The DUPAL anomaly: A large-scale isotopic mantle anomaly in the Southern Hemisphere. Nature 309: 753-757.

Hart SR, Schilling JG, and Powell JL (1973) Basalts from Iceland and along the Reykjanes Ridge: Sr isotope geochemistry. Nature Physical Science 246: 104-107.

Hawkins JW and Melchior JT (1985) Petrology of Mariana Trough and Lau Basin basalts. Journal of Geophysical Research 90: 431-468.

Haymon RM, Fornari DJ, Edwards MH, Carbotte S, Wright D, and Macdonald KC (1991) Hydrothermal vent distribution along the East Pacific Rise Crest $\left(9^{\circ} 09^{\prime}-54^{\prime} \mathrm{N}\right)$ and its relationship to magmatic and tectonic processes on fast-spreading mid-ocean ridges. Earth and Planetary Science Letters 104: 513-534.

Haymon RM, Fornari DJ, Von Damm KL, et al. (1993) Volcanic eruption of the mid-ocean ridge along the East Pacific Rise crest at $9^{\circ} 45-52^{\prime} \mathrm{N}$ : Direct submersible observations of seafloor phenomena associated with an eruption event in April, 1991. Earth and Planetary Science Letters 119: 85-101.

Hekinian R, Thompson G, and Bideau D (1989) Axial and off-axial heterogeneity of basaltic rocks from the East Pacific Rise at $12^{\circ} 35^{\prime} \mathrm{N}-12^{\circ} 51^{\prime} \mathrm{N}$ and $11^{\circ} 26^{\prime} \mathrm{N}-11^{\circ} 30^{\prime} \mathrm{N}$. Journal of Geophysical Research 94: 17437-17463.

Herzberg C (2004) Partial crystallization of mid-ocean ridge basalts in the crust and mantle. Journal of Petrology 45: 2389-2405.

Herzberg C, Asimow PD, Arndt N, et al. (2007) Temperatures in ambient mantle and plumes: Constraints from basalts, picrites, and komatiites. Geochemistry, Geophysics, Geosystems 8: Q02006. http://dx.doi.org/10.1029/2006gc001390.

Hess HH (1962) History of ocean basins. In: Engel AEJ, James HL, and Leonard BF (eds.) Petrologic Studies: A Volume in Honor of A. F. Buddington, pp. 599-620. Boulder, CO: Geological Society of America.

Hewitt IJ and Fowler AC (2009) Melt channelization in ascending mantle. Journal of Geophysical Research 114: B06210.

Hofmann AW (1988) Chemical differentiation of the Earth: The relationship between mantle, continental crust, and oceanic crust. Earth and Planetary Science Letters 90: 297-314.

Hofmann AW, Jochum KP, Seufert M, and White WM (1986) Nb and Pb in oceanic basalts: New constraints on mantle evolution. Earth and Planetary Science Letters 79: $33-45$

Hofmann AW and White WM (1982) Mantle plumes from ancient oceanic crust. Earth and Planetary Science Letters 57: 421-436. 
Hofmann AW and White WM (1983) Ba, Rb, and Cs in the Earth's mantle. Zeitschrift für Naturforschung 38: 256-266.

Holmes RC, Tolstoy M, Cochran JR, and Floyd JS (2008) Crustal thickness variations along the Southeast Indian Ridge $\left(100^{\circ}-116^{\circ} \mathrm{E}\right)$ from 2-D body wave tomography. Geochemistry, Geophysics, Geosystems 9: Q12020. http://dx.doi.org/10.1029/ $2008 \mathrm{gc002152}$

Hooft EEE, Detrick RS, Toomey DR, Collins JA, and Lin J (2000) Crustal thickness and structure along three contrasting spreading segments of the Mid-Atlantic Ridge, 33.5-35N. Journal of Geophysical Research 105: 8205-8226.

Ito E, White WM, and Goepel C (1987) The $\mathrm{O}, \mathrm{Sr}, \mathrm{Nd}$ and Pb isotope geochemistry of MORB. Chemical Geology 62: 157-176.

Johnson KTM and Dick HJB (1992) Open system melting and temporal and spatial variation of peridotite and basalt at the Atlantis II fracture zone. Journal of Geophysical Research 97: 9219-9241.

Jokat W, Ritzmann 0, Scmidt-Aursch MC, Drachev S, Gauger S, and Snow J (2003) Geophysical evidence for reduced melt production on the Arctic ultraslow Gakkel mid-ocean ridge. Nature 423: 962-965.

Jull M, Kelemen PB, and Sims K (2002) Consequences of diffuse and channelled porous melt migration on uranium series disequilibria. Geochimica et Cosmochimica Acta 66: 4133-4148.

Karson JA (1998) Internal structure of oceanic lithosphere: A perspective from tectonic windows. In: Buck WR, Delaney PT, Karson JA, and Lagabrielle Y (eds.) Faulting and Magmatism at Mid-Ocean Ridges, Geophysical Monograph Series, vol. 106, pp. 177-218. Washington DC: American Geophysical Union.

Karson JA (2002) Geologic structure of the uppermost oceanic crust created at fast- to intermediate-rate spreading centers. Annual Reviews of Earth and Planetary Sciences 30: 347-384.

Karson JA and Elthon D (1987) Evidence for variations in magma production along oceanic spreading centers: A critical appraisal. Geology 15: 127-131.

Karson JA, Klein EM, Hurst SD, et al. (2002) Structure of uppermost fast-spread oceanic crust exposed at the Hess Deep Rift: Implications for subaxial processes at the East Pacific Rise. Geochemistry, Geophysics, Geosystems 3: 1002. http://dx.doi. org/10.1029/2001gc000155

Karsten JL, Delaney JR, Rhodes JM, and Liias RA (1990) Spatial and temporal evolution of magmatic systems beneath the Endeavour Segment, Juan de Fuca Ridge: Tectonic and petrologic constraints. Journal of Geophysical Research 95: $19235-19256$

Kelemen PB and Dick HJB (1995) Focused melt flow and localized deformation in the upper mantle: Juxtaposition of replacive dunite and ductile shear zones in the Josephine peridotite, SW Oregon. Journal of Geophysical Research 100: 423-438.

Kelemen PB, Hirth G, Shimizu N, Spiegelman M, and Dick HJ (1997) A review of melt migration processes in the adiabatically upwelling mantle beneath oceanic spreading ridges. Philosophical Transactions of the Royal Society, Series A 355: 283-318.

Kelemen PB, Shimizu N, and Salters VJM (1995) Extraction of mid-ocean-ridge basalt from the upwelling mantle by focused flow of melt in dunite channels. Nature 375: 747-753.

Kent GM, Harding AJ, and Orcutt JA (1990) Evidence for a smaller magma chamber beneath the East Pacific Rise at 9०30' N. Nature 344: 650-652.

Kinzler RJ and Grove TL (1992) Primary magmas of mid-ocean ridge basalts, 2: Applications. Journal of Geophysical Research 97: 6907-6926.

Klein EM and Langmuir CH (1987) Ocean ridge basalt chemistry, axial depth, crustal thickness and temperature variations in the mantle. Journal of Geophysical Research 92: 8089-8115

Klein EM, Langmuir CH, Zindler A, and Staudigel BH (1988) Isotope evidence of a mantle convection boundary at the Australian-Antarctic discordance. Nature 333: 623-629.

Klingelhöfer F, Géli L, Matias L, Steinsland N, and Mohr J (2000) Crustal structure of a super-slow spreading centre: A seismic refraction study of Mohns Ridge, $72^{\circ} \mathrm{N}$. Geophysical Journal International 141: 509-526.

Kodaira S, Mjelde R, Gunnarsson K, Shirobara H, and Shimamura H (1997) Crustal structure of the Kolbeinsey Ridge, North Atlantic, obtained by use of ocean bottom seismographs. Journal of Geophysical Research 102: 3131-3151.

Koppers AAP, Staudigel H, and Duncan RA (2003) High-resolution ${ }^{40} \mathrm{Ar} /{ }^{39} \mathrm{Ar}$ dating of the oldest oceanic basement basalts in the western Pacific basin. Geochemistry, Geophysics, Geosystems 4(11): 8914. http://dx.doi.org/10.1029/2003gc000574.

Lachenbruch AH (1976) Dynamics of a passive spreading center. Journal of Geophysical Research 81: 1883-1902.

Langmuir CH, Bender JF, and Batiza R (1986) Petrologic and tectonic segmentation of the East Pacific Rise between $5^{\circ} 30^{\prime}-14^{\circ} 30^{\prime}$ N. Nature 322: 422-429.

Langmuir CH and Hanson GN (1980) An evaluation of major element heterogeneity in the mantle sources of basalts. Philosophical Transactions of the Royal Society Series A 297: 383-407.
Langmuir CH, Klein EM, and Plank T (1992) Petrological systematics of mid-ocean ridge basalts: Constraints on melt generation beneath oceanic ridges. In: Morgan JP, Blackman DK, and Sinton JM (eds.) Mantle Flow and Melt Generation at Mid-Ocean Ridges. Geophysical Monograph Series, vol. 71, pp. 183-280. Washington, DC: American Geophysical Union.

Laubier M, Schiano P, Doucelance R, Ottolini L, and Laporte D (2007) Olivine-hosted melt inclusions and melting processes beneath the FAMOUS zone (Mid-Atlantic Ridge). Chemical Geology 240: 129-150

Liang Y, Schiemenz A, Hesse MA, Parmentier EM, and Hesthaven JS (2010) Highporosity channels for melt migration in the mantle: Top is the dunite and bottom is the harzburgite and Iherzolite. Geophysical Research Letters 37: L15306. http://dx. doi.org/10.1029/2010gl044162.

Lissenberg CJ and Dick HJB (2008) Melt-rock reaction in the lower oceanic crust and its implications for the genesis of mid-ocean ridge basalt. Earth and Planetary Science Letters 271: 311-325.

Lyubetskaya T and Korenaga J (2007) Chemical composition of Earth's primitive mantle and its variance: 1. Method and results. Journal of Geophysical Research 112: B03211. http://dx.doi.org/10.1029/2005jb004223.

Macdonald KC (2001) Seafloor spreading: Mid-ocean ridge tectonics. In: Steele J, Thorpe S, and Turekian K (eds.) Encyclopedia of Ocean Sciences, pp. 1798-1813. San Diego, CA: Academic Press.

Macdonald KC, Scheirer DS, and Carbotte SM (1991) Mid-ocean ridges: Discontinuities, segments and giant cracks. Science 253: 986-994.

Macdonald KC, Fox PJ, Perram LJ, et al. (1988) A new view of the mid-ocean ridge from the behaviour of ridge-axis discontinuities. Nature 335: 217-225

Maclennan J (2008) Concurrent mixing and cooling of melts under Iceland. Journal of Petrology 49: 1931-1953.

MacLeod CJ, Searle RC, Murton BJ, et al. (2009) Life cycle of oceanic core complexes Earth and Planetary Science Letters 287: 333-344.

McClain KJ and Lewis BTR (1982) Geophysical evidence for the absence of a crustal magma chamber under the northern Juan de Fuca Ridge: A contrast with ROSE results. Journal of Geophysical Research 87: 8477-8489.

McDonough WF and Sun S-S (1995) The composition of the Earth. Chemical Geology 120: 223-253.

McKenzie D and Bickle MJ (1988) The volume and composition of melt generated by extension of the lithosphere. Journal of Petrology 29: 625-679.

Meisel T, Walker RJ, and Morgan JW (1996) The osmium isotopic composition of the Earth's primitive upper mantle. Nature 383: 517-520.

Meyzen CM, Blichert-Toft J, Ludden JN, Humler E, Mevel C, and Albarede F (2007) Isotopic portrayal of the Earth's upper mantle flow field. Nature 447: 1069-1074.

Michael PJ and Bonatti E (1985) Peridotite composition from the North Atlantic: Regional and tectonic variations and implications for partial melting. Earth and Planetary Science Letters 73: 91-104.

Michael PJ and Cornell WC (1998) Influence of spreading rate and magma supply on crystallization and assimilation beneath mid-ocean ridges: Evidence from chlorine and major element chemistry of mid-ocean ridge basalts. Journal of Geophysical Research 103: 18325-18356

Michael PJ, Langmuir CH, Dick HJ, et al. (2003) Magmatic and amagmatic seafloor generation at the ultraslow-spreading Gakkel ridge, Arctic Ocean. Nature 423: 956-961.

Muehlenbachs K and Byerly G (1982) ${ }^{18} 0$ enrichment of silicic magmas caused by crystal fractionation at the Galapagos Spreading Center. Contributions to Mineralogy and Petrology 79: 76-79.

Muehlenbachs K and Clayton RN (1972) Oxygen isotope studies of fresh and weathered submarine basalts. Canadian Journal of Earth Sciences 9: 172-184.

Muir ED and Tilley CE (1964) Basalts from the northern part of the rift zone of the Mid-Atlantic Ridge. Journal of Petrology 5: 409-434.

Muller MR, Minshull TA, Timothy A, and White RS (1999) Segmentation and melt supply at the Southwest Indian Ridge. Geology 27: 867-870.

Müller RD, Sdrolias M, Gaina C, and Roest WR (2008a) Age, spreading rates, and spreading asymmetry of the world's ocean crust. Geochemistry, Geophysics, Geosystems 9: Q04006. http://dx.doi.org/10.1029/2007gc001743.

Müller RD, Sdrolias M, Gaina C, Steinberger B, and Heine C (2008b) Long-term sea-level fluctuations driven by ocean basin dynamics. Science 319: 1357-1362.

Natland JH (1989) Partial melting of a lithologically heterogeneous mantle, 1: Inferences from crystallization histories of magnesian abyssal tholeiites from the Siqueiros Fracture Zone. In: Saunders AD and Norry M (eds.) Magmatism in the Ocean Basins, Geological Society Special Publication 42, pp. 41-77. London: Geological Society of London.

Navin DA, Peirce C, and Sinha MC (1998) The RAMESSES experiment II. Evidence for accumulated melt beneath a slow spreading ridge from wide-angle refraction and 
multichannel reflection seismic profiles. Geophysical Journal International 135: $746-772$.

Newsom HE, White WM, Jochum KP, and Hofmann AW (1986) Siderophile and chalcophile element abundances in oceanic basalts, $\mathrm{Pb}$ isotope evolution and growth of the Earth's core. Earth and Planetary Science Letters 80: 299-313.

Nielsen RL, Crum J, Bourgeois R, et al. (1995) Melt inclusions in high-An plagioclase from the Gorda Ridge: An example of the local diversity of MORB parent magmas. Contributions to Mineralogy and Petrology 122: 34-50.

Niu Y and Batiza R (1997) Trace element evidence from seamounts for recycled oceanic crust in the eastern Pacific mantle. Earth and Planetary Science Letters 148: 471-483.

Niu Y, Bideau D, Hékinian R, and Batiza R (2001) Mantle compositional control on the extent of melting, crust production, gravity anomaly and ridge morphology: A case study at the Mid-Atlantic Ridge 33-35 N. Earth and Planetary Science Letters 186: 383-399.

Niu Y and O'Hara MJ (2008) Global correlations of ocean ridge basalt chemistry with axial depth: A new perspective. Journal of Petrology 49: 633-664

Niu Y and O'Hara MJ (2009) MORB mantle hosts the missing Eu (Sr, Nb, Ta and Ti) in the continental crust: New perspectives on crustal growth, crust-mantle differentiation and chemical structure of oceanic upper mantle. Lithos 112: $1-17$.

O'Hara MJ (1968) The bearing of phase equilibria studies in synthetic and natural systems on the origin and evolution of basic and ultrabasic rocks. Earth-Science Reviews 4: 69-133.

O'Neill HSC and Palme H (2008) Collisional erosion and the non-chondritic composition of the terrestrial planets. Philosophical Transactions of the Royal Society Series A 366: 4205-4238.

Oxburgh ER (1965) Volcanism and mantle convection. Philosophical Transactions of the Royal Society Series A 258: 142-144.

Oxburgh ER (1980) Heat flow and magma genesis. In: Hargraves RB (ed.) Physics of Magmatic Processes, pp. 161-199. Princeton: Princeton University Press.

Pearce JA and Stern RJ (2006) The origin of back-arc basin magmas: Trace element and isotope perspectives. In: Christie DM, Fisher CR, Lee S-M, and Givens S (eds.) Back-Arc Spreading Systems: Geological, Biological, Chemical, and Physical Interactions, Geophysical Monograph Series, vol. 166, pp. 63-86. Washington, DC American Geophysical Union.

Perfit MR and Chadwick WW (1998) Magmatism at mid-ocean ridges: Constraints from volcanological and geochemical investigations. In: Buck WR, Delaney PT, and Karson JA (eds.) Faulting and Magmatism at Mid-Ocean Ridges. Geophysical Monograph Series, vol. 106, pp. 59-115. Washington, DC: American Geophysical Union.

Perfit MR, Fornari DJ, Ridley WI, et al. (1996) Recent volcanism in the Siqueiros transform fault: Picritic basalts and implications for MORB magma genesis. Earth and Planetary Science Letters 141: 91-108.

Perfit MR, Fornari DJ, Smith MC, Bender JF, Langmuir CH, and Haymon RM (1994) Small-scale spatial and temporal variations in mid-ocean ridge crest magmatic processes. Geology 22: 375-379.

Phipps Morgan J (1987) Melt migration beneath mid-ocean spreading centers. Geophysical Research Letters 14: 1238-1241.

Phipps Morgan J (2001) Thermodynamics of pressure release melting of a veined plum pudding mantle. Geochemistry, Geophysics, Geosystems 2: 1001. http://dx.doi.org/ 10.1029/2000gc000049.

Phipps Morgan J and Chen YJ (1993) The genesis of oceanic crust; magma injection, hydrothermal circulation, and crustal flow. Journal of Geophysical Research 98: 6283-6297.

Plank T and Langmuir CH (1988) An evaluation of the global variations in the major element chemistry of arc basalts. Earth and Planetary Science Letters 90: 349-370

Plank T and Langmuir CH (1992) Effects of the melting regime on the composition of oceanic crust. Journal of Geophysical Research 97: 19749-19770.

Putirka KD, Perfit M, Ryerson FJ, and Jackson MG (2007) Ambient and excess mantle temperatures, olivine thermometry, and active vs. passive upwelling. Chemical Geology 241: 177-206.

Pyle D, Christie DM, and Mahoney JJ (1992) Resolving an isotopic boundary within the Australian-Antarctic discordance. Earth and Planetary Science Letters 112: 161-178.

Rabinowicz M and Toplis MJ (2009) Melt segregation in the lower part of the partially molten mantle zone beneath an oceanic spreading centre: Numerical modelling of the combined effects of shear segregation and compaction. Journal of Petrology 50: 1071-1106

Reisberg L, Rouxel 0, Ludden J, Staudigel H, and Zimmermann C (2008) Re-Os results from ODP Site 801: Evidence for extensive Re uptake during alteration of oceanic crust. Chemical Geology 248: 256-271.
Reynolds JR, Langmuir CH, Bender JF, Kastens KA, and Ryan WBF (1992) Spatial and temporal variability in the geochemistry of basalt from the East Pacific Rise. Nature 359: 493-499.

Roeder PL and Emslie RF (1970) Olivine-liquid equilibrium. Contributions to Mineralogy and Petrology 29: 275-289.

Rowley DB (2002) Rate of plate creation and destruction: 180 Ma to present. Geological Society of America Bulletin 114: 927-933.

Rowley DB (2008) Extrapolating oceanic age distributions: Lessons from the Pacific region. Journal of Geology 116: 587-598.

Roy-Barman M, Wasserburg GJ, Papanastassiou DA, and Chaussidon M (1998) Osmium isotopic compositions and Re-Os concentrations in sulfide globules from basaltic glasses. Earth and Planetary Science Letters 154: 331-347.

Rubin KH and Sinton JM (2007) Inferences on mid-ocean ridge thermal and magmatic structure from MORB compositions. Earth and Planetary Science Letters 260: 257-276.

Rubin KH, Sinton JM, Maclennan J, and Hellebrand E (2009) Magmatic filtering of mantle compositions at mid-ocean-ridge volcanoes. Nature Geoscience 2: $321-328$.

Rubin KH, Smith MC, Bergmanis EC, Perfit MR, Sinton JM, and Batiza R (2001) Geochemical heterogeneity within mid-ocean ridge lava flows: Insights into eruption, emplacement and global variations in magma generation. Earth and Planetary Science Letters 188: 349-367.

Saal AE, Nagle AN, Myers C, et al. (2008) Evidence for a heterogeneous asthenosphere from intra-transform and seamount lavas. Eos, Transactions of the American Geophysical Union 89: V31D-V1985D

Schilling J-G (1973) Iceland mantle plume: Geochemical study of the Reykjanes Ridge. Nature 242: 565-571.

Schilling J-G (1975) Rare-earth variations across 'normal segments' of the Reykjanes Ridge, $60^{\circ}-53^{\circ} \mathrm{N}$, Mid-Atlantic Ridge, $29^{\circ} \mathrm{S}$, and East Pacific Rise, $2^{\circ}-19^{\circ} \mathrm{S}$, and evidence on the composition of the underlying low-velocity layer. Journal of Geophysical Research 80: 1459-1473.

Schilling J-G (1985) Upper mantle heterogeneities and dynamics. Nature 314: 62-67.

Schilling J-G, Zajac M, Evans R, et al. (1983) Petrologic and geochemical variations along the Mid-Atlantic Ridge from $29^{\circ} \mathrm{N}$ to $73^{\circ} \mathrm{N}$. American Journal of Science 283: 510-586.

Scott DR and Stevenson DJ (1989) A self-consistent model of melting, magma migration, and buoyancy-driven circulation beneath mid-ocean ridges. Journal of Geophysical Research 94: 2973-2988.

Sempere J-D, Lin J, Brown HS, Schouten H, and Purdy GM (1993) Segmentation and morphotectonic variations along a slow-spreading center: The Mid-Atlantic Ridge $\left(24^{\circ} 00^{\prime} \mathrm{N}-30^{\circ} 40^{\prime} \mathrm{N}\right)$. Marine Geophysical Research 15: 153-200.

Shank T, et al. (2003) Deep submergence synergy: Alvin and ABE explore the Galápagos Rift at $86^{\circ}$ W. Eos, Transactions of the American Geophysical Union 41(84): 425.

Shen Y and Forsyth DW (1995) Geochemical constraints on initial and final depth of melting beneath mid-ocean ridges. Journal of Geophysical Research 100: 2211-2237.

Shimizu N (1998) The geochemistry of olivine-hosted melt inclusions in a FAMOUS basalt ALV519-4-1. Physics of the Earth and Planetary Interiors 107: 183-201.

Sims KWW, Goldstein SJ, Blichert-Toft J, et al. (2002) Chemical and isotopic constraints on the generation and transport of melt beneath the East Pacific Rise. Geochimica et Cosmochimica Acta 66: 3481-3504

Singh SC, Crawford WC, Carton $\mathrm{H}$, et al. (2006) Discovery of a magma chamber and faults beneath a Mid-Atlantic Ridge hydrothermal field. Nature 442: 1029-1032.

Sinton CW, Christie DM, Coombs VL, Nielsen RL, and Fisk MR (1993) Near primary melt inclusions in anorthite phenocrysts from the Galapagos Platform. Earth and Planetary Science Letters 119: 527-537.

Sinton JM and Detrick RS (1992) Mid-ocean ridge magma chambers. Journal of Geophysical Research 97: 197-216.

Sinton JM, Ford LL, Chappell B, and McCulloch MT (2003) Magma genesis and mantle heterogeneity in the Manus back-arc basin. Papua New Guinea. Journal of Petrology 44: 159-195.

Sinton JM and Fryer P (1987) Mariana Trough lavas from $18^{\circ} \mathrm{N}$ : Implications for the origin of back-arc basin basalts. Journal of Geophysical Research 92: 12782-12802.

Sinton JM. Smaglik SM, and Mahoney JJ (1991) Magmatic processes at superfast spreading mid-ocean ridges: Glass compositional variations along the East Pacific Rise $13^{\circ}-23^{\circ}$ S. Journal of Geophysical Research 96: 6133-6155.

Smallwood JR and White RS (1998) Crustal accretion at the Reykjanes Ridge, $61^{\circ}-62^{\circ}$ N. Journal of Geophysical Research 103: 5185-5201.

Smith DK, Cann JR, and Escartin J (2006) Widespread active detachment faulting and core complex formation near $13^{\circ} \mathrm{N}$ on the Mid-Atlantic Ridge. Nature 442: 440-443. 
Smith MC, Perfit MR, Fornari DJ, et al. (2001) Magmatic processes and segmentation at a fast spreading mid-ocean ridge: Detailed investigation of an axial discontinuity on the East Pacific Rise crest at 9॰37' N. Geochemistry, Geophysics, Geosystems 2: 1040. http://dx.doi.org/10.1029/2000gc000134.

Snow JE, Hart SR, and Dick HJB (1994) Nd and Sr isotope evidence linking mid-oceanridge basalts and abyssal peridotites. Nature 37: 57-60.

Sobolev AV and Shimizu N (1993) Ultra-depleted primary melt included in an olivine from the Mid-Atlantic Ridge. Nature 363: 151-154.

Sohn RA, Barclay AH, and Webb SC (2004) Microearthquake patterns following the 1998 eruption of Axial Volcano, Juan de Fuca Ridge: Mechanical relaxation and thermal strain. Journal of Geophysical Research 109: B01101. http://dx.doi.org/ 10.1029/2003jb002499

Sohn RA, Willis C, Humphris S, et al. (2008) Explosive volcanism on the ultraslowspreading Gakkel ridge, Arctic Ocean. Nature 453: 1236-1238.

Soule SA, Fornari DJ, Perfit MR, and Rubin KH (2007) New insights into mid-ocean ridge volcanic processes from the 2005-2006 eruption of the East Pacific Rise, $9^{\circ} 46^{\prime} \mathrm{N}-9^{\circ} 56^{\prime} \mathrm{N}$. Geology 35: 1079-1082.

Sours-Page R, Johnson KTM, Nielsen RL, and Karsten JL (1999) Local and regional variation of MORB parent magmas: Evidence from melt inclusions from the Endeavour Segment of the Juan de Fuca Ridge. Contributions to Mineralogy and Petrology 134: 342-363.

Sours-Page R, Nielsen RL, and Batiza R (2002) Melt inclusions as indicators of parental magma diversity on the northern East Pacific Rise. Chemical Geology 183: 237-261.

Spiegelman M and Kelemen PB (2003) Extreme chemical variability as a consequence of channelized melt transport. Geochemistry, Geophysics, Geosystems 4: 1055. http://dx.doi.org/10.1029/2002gc000336.

Spiegelman M and McKenzie D (1987) Simple 2-D models for melt extraction at midocean ridges and island arcs. Earth and Planetary Science Letters 83: 137-152.

Stakes DS, Perfit MR, Tivey MA, Caress DW, Ramirez TM, and Maher N (2006) The Cleft revealed: Geologic, magnetic, and morphologic evidence for construction of upper oceanic crust along the southern Juan de Fuca Ridge. Geochemistry, Geophysics, Geosystems 7: Q04003. http://dx.doi.org/10.1029/2005GC001038.

Sturm ME, Klein EM, Graham DW, and Karsten J (1999) Age constraints on crusta recycling to the mantle beneath the southern Chile Ridge; He-Pb-Sr-Nd isotope systematics. Journal of Geophysical Research 104: 5097-5114.

Sun S-S and McDonough WF (1989) Chemical and isotopic systematics of oceanic basalts: Implications for mantle composition and processes. In: Saunders AD and Norry MJ (eds.) Magmatism in the Ocean Basins, Geological Society Special Publication 42, pp. 313-345. London: Geological Society of London.

Tarney J, Saunders AD, Mattey DP, Wood DA, and Marsh NG (1981) Geochemical aspects of back-arc spreading in the Scotia Sea and western Pacific. Philosophical Transactions of the Royal Society Series A 300: 263-285.

Tarney J, Saunders AD, and Weaver SD (1977) Geochemistry of volcanic rocks from the island arcs and marginal basins of the Scotia Sea region. In: Talwani $M$ and Pitman WC (eds.) Island Arcs, Deep Sea Trenches, and Backarc Basins, pp. 367-377. Washington, DC: American Geophysical Union.

Tolstoy M, Bohnenstiehl DR, Edwards MH, and Kurras GJ (2001) Seismic character of volcanic activity at the ultraslow-spreading Gakkel Ridge. Geology 29: 1139-1142.

Tolstoy M, Cowen JP, Baker ET, et al. (2006) A sea-floor spreading event captured by seismometers. Science 314: 1920-1922.

Toomey DR, Purdy GM, Solomon SC, and Wilcock WSD (1990) The three-dimensional seismic velocity structure of the East Pacific Rise near latitude $9^{\circ} 30^{\prime} \mathrm{N}$. Nature 347: 639-645

Tucholke BE, Behn MD, Buck WR, and Lin J (2008) Role of melt supply in oceanic detachment faulting and formation of megamullions. Geology 36: 455-458

Umino S, Crispini L, Tartarotti P, et al. (2008) Origin of the sheeted dike complex at superfast spread East Pacific Rise revealed by deep ocean crust drilling at Ocean Drilling Program Hole 1256D. Geochemistry, Geophysics, Geosystems 9: 006008 http://dx.doi.org/10.1029/2007gc001760.

Vallier TL, Jenner GA, Frey FA, et al. (1991) Subalkaline andesite from Valu Fa Ridge, a back-arc spreading center in sourthern Lau Basin: Petrogenesis, comparitive chemistry and tectonic implications. Chemical Geology 91: 227-256.

Van Ark EM, Detrick RS, Canales JP, et al. (2007) Seismic structure of the Endeavour Segment, Juan de Fuca Ridge: Correlations with seismicity and hydrothermal activity. Journal of Geophysical Research 112: B02401.

Vera EE, Buhl P, Mutter JC, et al. (1990) The structure of 0-0.2 My old oceanic crust at $9^{\circ} \mathrm{N}$ on the East Pacific Rise from expanded spread profiles. Journal of Geophysical Research 95: 15529-15556.
Villiger S, Müntener 0, and UImer P (2007) Crystallization pressures of mid-ocean ridge basalts derived from major element variations of glasses from equilibrium and fractional crystallization experiments. Journal of Geophysical Research 112: B01202.

Von Bargen N and Waff HS (1986) Permeabilities, interfacial areas and curvatures of partially molten systems: Results of numerical computations of equilibrium microstructures. Journal of Geophysical Research 91: 9261-9276.

Walker RJ, Carlson RW, Shirey SB, and Boyd FR (1989) Os, Sr, Nd, and Pb isotope systematics of southern African peridotite xenoliths: Implications for the chemical evolution of the subcontinental mantle. Geochimica et Cosmochimica Acta 53: $1583-1595$.

Wanless VD, Perfit MR, Ridley WI, Wallace PJ, Grimes CB, and Klein EM (2011) Volatile abundances and oxygen isotopes in basaltic to dacitic lavas on mid-ocean ridges: The role of assimilation at spreading centers. Chemical Geology 287: $54-65$.

Wark DA, Williams CA, Watson EB, and Price JD (2003) Reassessment of pore shapes in microstructurally equilibrated rocks, with implications for permeability of the upper mantle. Journal of Geophysical Research 108: 2050. http://dx.doi.org/ 10.1029/2001jb001575.

Warren JM, Shimizu N, Sakaguchi C, Dick HJB, and Nakamura E (2009) An assessment of upper mantle heterogeneity based on abyssal peridotite isotopic compositions. Journal of Geophysical Research 114: B12203.

Waters CL, Sims KWW, Perfit MR, Blichert-Toft J, and Blusztajn J (2011) Perspective on the genesis of E-MORB from chemical and isotopic heterogeneity at 9- $0^{\circ} \mathrm{N}$ Eas Pacific Rise. Journal of Petrology 52: 565-602.

Wendt Jl, Regelous M, Niu Y, Hekinian R, and Collerson KD (1999) Geochemistry of lavas from the Garrett Transform fault: Insights into mantle heterogeneity beneath the eastern Pacific. Earth and Planetary Science Letters 173: 271-284.

White RS, McKenzie D, and O'Nions RK (1992) Oceanic crustal thickness from seismic measurements and rare earth element inversions. Journal of Geophysical Research 97: 19683-19715

White RS, Minshull TA, Bickle MJ, and Robinson CJ (2001) Melt generation at very slow-spreading oceanic ridges: Constraints from geochemical and geophysical data. Journal of Petrology 42: 1171-1196.

White SM, Haymon RM, Fornari DJ, Perfit MR, and Macdonald KC (2002) Correlation between volcanic and tectonic segmentation of fast-spreading ridges: Evidence from volcanic structures and lava flow morphology on the East Pacific Rise at $9^{\circ}-10^{\circ} \mathrm{N}$. Journal of Geophysical Research 107: 2173. http://dx.doi.org/10.1029/ 2001 ib000571.

White SM, Mason JL, Macdonald KC, Perfit MR, Wanless VD, and Klein EM (2009) Significance of widespread low effusion rate eruptions over the past two million years for delivery of magma to the overlapping spreading centers at $9^{\circ} \mathrm{N}$ East Pacific Rise. Earth and Planetary Science Letters 280: 175-184.

White WM (2010) Oceanic island basalts and mantle plumes: The geochemical perspective. Annual Review of Earth and Planetary Sciences 38: $133-160$.

White WM, Hofmann AW, and Puchelt H (1987) Isotope geochemistry of Pacific mid-ocean ridge basalts. Journal of Geophysical Research 92: 4881-4893.

White WM and Schilling J-G (1978) The nature and origin of geochemical variation in Mid-Atlantic Ridge basalts from the Central North Atlantic. Geochimica et Cosmochimica Acta 42: 1501-1516.

Winpenny B and Maclennan J (2011) A partial record of mixing of mantle melts preserved in Icelandic phenocrysts. Journal of Petrology 52: 1791-1812.

Yamamoto M, Morgan JP, and Morgan WJ (2007) Global plume-fed asthenosphere flow II: Application to the geochemical segmentation of ridges. In: Foulger GR and Jurdy DM (eds.) Plates, Plumes, and Planetary Processes, Geological Society of America Special Papers 430, pp. 189-208. Boulder, CO: Geological Society of America.

Yang Y, Forsyth DW, and Weeraratne DS (2007) Seismic attenuation near the East Pacific Rise and the origin of the low-velocity zone. Earth and Planetary Science Letters 258: 260-268.

Zhang G-L, Zeng Z-G, Beier C, Yin X-B, and Turner S (2010) Generation and evolution of magma beneath the East Pacific Rise: Constraints from U-series disequilibrium and plagioclase-hosted melt inclusions. Journal of Volcanology and Geothermal Research 193: 1-17.

Zhu W, Gaetani GA, Fusseis F, Montesi LGJ, and De Carlo F (2011) Microtomography of partially molten rocks: Three-dimensional melt distribution in mantle peridotite. Science 332: 88-91. 